
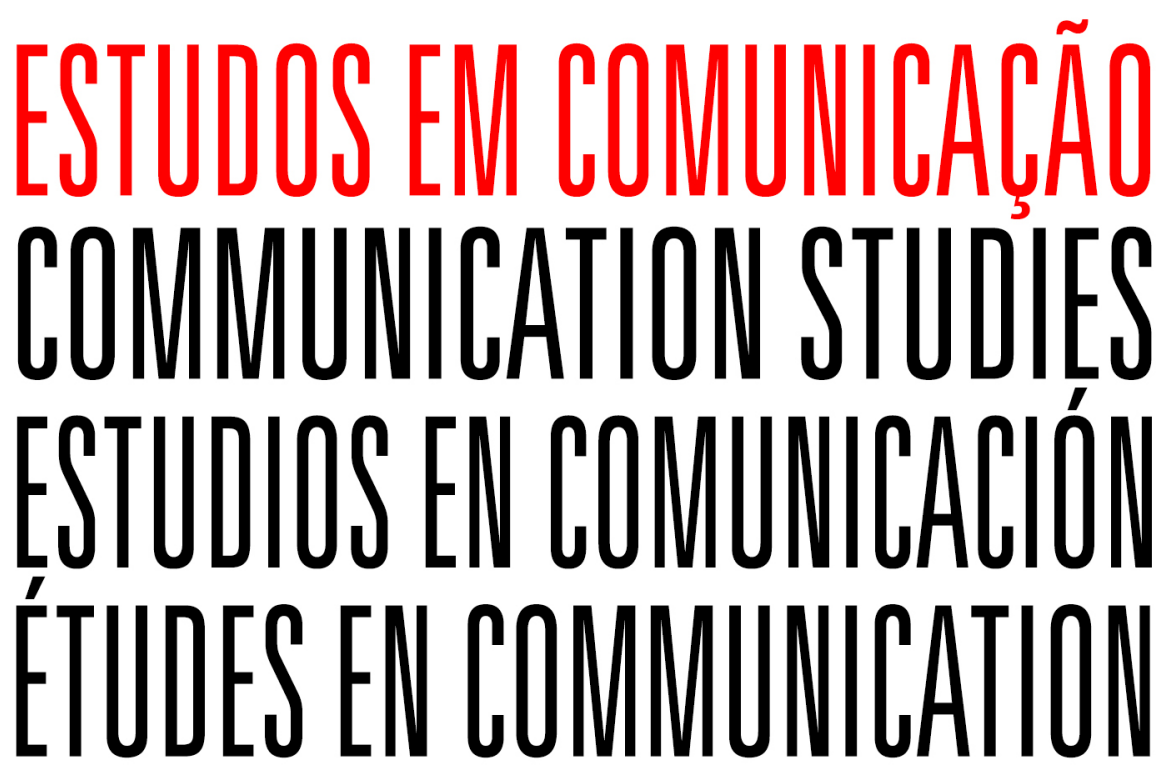

REVISTA . REVIEW . REVISTA . MAGAZINE

ND20 . DEZ'2015

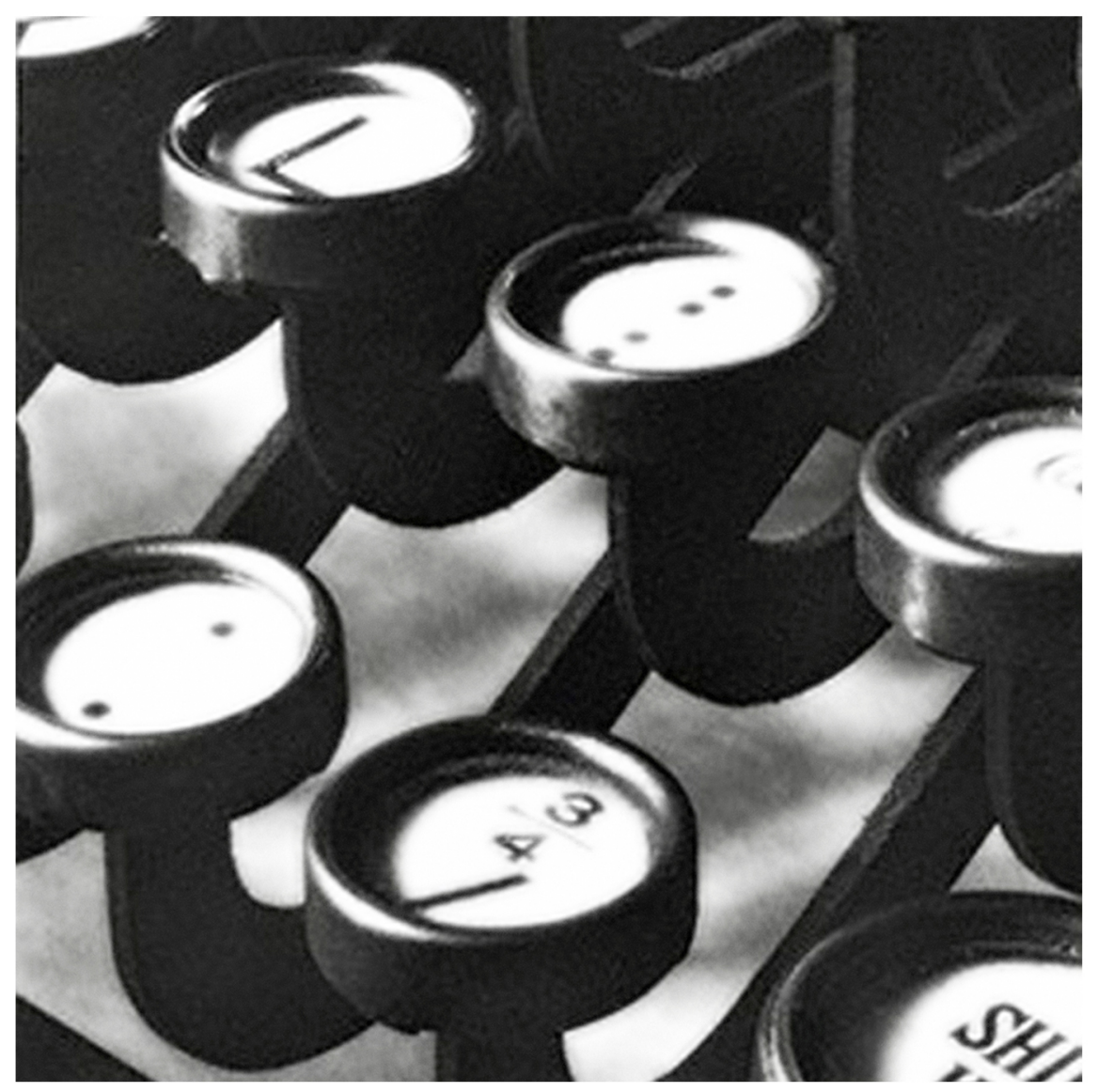


$\bigoplus$

$\bigoplus$

$\oplus$ 
EDITORS [EDITORES]

João Carlos Correia (Universidade da Beira Interior, Portugal)

Anabela Gradim (Universidade da Beira Interior, Portugal)

INTERNATIONAL SCIENTIFIC BOARD [PAINEL CIENTÍFICO INTERNACIONAL]

António Fidalgo (Universidade da Beira Interior, Portugal)

Afonso Albuquerque (Universidade Federal Fluminense, Brasil)

Alfredo Vizeu (Universidade Federal de Pernambuco, Brasil)

António Bento (Universidade da Beira Interior, Portugal)

Ana Serrano Telleria (Universidade da Beira Interior, Portugal)

Ana Catarina Pereira (Universidade da Beira Interior, Portugal)

Barbie Zelizer (University of Pennsylvania, USA)

Catarina Rodrigues (Universidade da Beira Interior, Portugal)

Catarina Moura (Universidade da Beira Interior, Portugal)

Catarina Moura (Universidade da Beira Interior, Portugal)

Cláudia Alvares (Universidade Lusófona de Humanidades e Tecnologias Escola de Comunica-

ção. Artes e Tecnologias da Informação, Portugal)

Colin Sparks (University of Westminster, United Kingdom)

Eduardo Camilo (Universidade da Beira Interior, Portugal)

Eduardo Meditsch (Universidade Federal de Santa Catarina, Brasil)

François Heinderyckx (Université Libre de Bruxelles, Belgique)

Elias Machado (Universidade Federal de Santa Catarina, Brasil)

Francisco Costa Pereira (Escola Superior de Comunicação Social, Portugal)

Gil Ferreira (Universidade Católica Portuguesa)

Helena Sousa (Universidade do Minho, Portugal)

Ivone Ferreira (Universidade da Beira Interior, Portugal)

Javier Díaz Noci (Universidad del País Vasco, Espanã)

Jean Marc-Ferry (Université Libre de Bruxelles, Institut d'Études Européennes, Belgique)

João Pissarra Esteves (Universidade Nova de Lisboa, Portugal)

João Canavilhas (Universidade da Beira Interior, Portugal)

Joaquim Paulo Serra (Universidade da Beira Interior, Portugal)

Jorge Pedro Sousa (Universidade Fernando Pessoa, Portugal)

José Bragança de Miranda (Universidade Lusófona ; Universidade Nova de Lisboa, Portugal)

Liesbet van Zoonen (University of Amsterdam, Holanda)

Luís Costa Nogueira (Universidade da Beira Interior, Portugal)

Manuel Pinto (Universidade do Minho, Portugal)

Mark Deuze (Indiana University, USA)

Maria João Silveirinha (Universidade de Coimbra, Portugal)

Marisa Torres Silva (FCSH, CIMJ, Portugal)

Mário Mesquita (Escola Superior de Comunicação Social de Lisboa, Portugal)

Marcos Palácios (Universidade Federal da Bahia, Brasil)

Martin Jay (University of California, Berkeley, USA)

Miguel Rodrigo Alsina (Universitat Pompeu Fabra, España)

Michael Gurevitch (University of Maryland, USA) 
Nelson Traquina (Universidade Nova de Lisboa, Portugal)

Nico Carpentier (Vrije Universiteit Brussel -VUB- , Katholieke Universiteit Brussel - KUB)

Nathalie Zaccai - Reyners (Université Libre de Bruxelles, Belgique)

Paula Espírito Santo (Instituto Superior de Ciências Sociais e Políticas, Universidade Técnica

de Lisboa, Portugal)

Peter Dahlgren (Lunds Universitet, Sweden)

Pedro Coelho (SIC, Jornalista; Investigador)

Ramón Salaverría (Universidad de Navarra, España)

Stephen K. White (University of Virgínia, EUA)

Rosental Calmon Alves (University of Texas, USA)

Steve Reese (University of Texas, USA)

Susan Buck-Morss (Cornell University)

Tito Cardoso e Cunha (Universidade da Beira Interior, Portugal)

Todd Gitlin (Columbia University, USA)

Xosé Lópes García (Universidad Santiago de Compostela, España)

\section{GRAPHICAL DIRECTOR [DIRECÇÃO GRÁFICA]}

Catarina Moura

\section{COLLABORATORS [COLABORADORES]}

Filomena Matos, Susana Costa, Cristina Lopes, António Tomé e Manuela Penafria

\section{CREDITS [FICHA TÉCNICA]}

(C) Estudos em Comunicação [Communication Studies]

LabCom.IFP - Comunicação, Filosofia e Humanidades

UBI - Universidade da Beira Interior

Universidade da Beira Interior - FAL/LabCom

Rua Marquês D’Ávila e Bolama

6201-001 Covilhã, Portugal

ISSN : 1646-4923

ISSN (suporte electrónico) : 1646-4974

DOI : $10.20287 / \mathrm{ec}$

DOI [ $\left.{ }^{\circ} 20\right]: 10.20287 /$ ec.n20

Semestral periodicity [Periodicidade semestral]

Contacts [Contatos] : joao.correia@labcom.ubi.pt, anabela.gradim@labcom.ubi.pt

Call for papers opened on : January 21th, 2015

Manuscript Submission : November 6th, 2015

Acceptance Notification : November 30th, 2015

Publication : December 18th, 2015 


\section{Index [Índice]}

New informative platforms and traditional media: synergy or antagonism?. A comparative analysis of 2010 presidential coverage in the daily newspaper O Estado de São Paulo and webpage Estadao.com

por Michele Goulart Massuchin \& Emerson Urizzi Cervi

A mediação das relações sociais nas redes sociais virtuais: do ciberespaço ao ciberterritório

por Rubens Staloch \& Clovis Reis

As lutas dos indignados espanhóis em 25 de setembro de 2012 em Madrid

por Diego de Carvalho

Poética Literária e Poética Cinematográfica: Um Confronto nas Terras Médias de $\mathbf{O}$ Hobbit

por Vanda de Sousa \& Cristina Ponte

Journalism and Mass Communication Training in Nigeria: Some Critical Thoughts por Olusegun W. Ojomo

Como lidar com clientes difíceis. Uma releitura do trabalho do Dr. Rick Brinkman e Dr. Rick Kirschner voltado para o atendimento ao cliente por Guilherme Dias \& Marcos Isern

On the implications of non-translation in Portuguese advertising: names in cosmetic products as a case in point

por Sandra Gonçalves Tuna \& Elsa Simões Lucas Freitas 
$\bigoplus$

$\bigoplus$

$\oplus$ 


\title{
New informative platforms and traditional media: synergy or antagonism?. A comparative analysis of 2010 presidential coverage in the daily newspaper O Estado de São Paulo and webpage Estadao.com
}

\author{
Michele Goulart Massuchin \& Emerson Urizzi Cervi \\ Universidade Federal do Maranhão / Universidade Federal do Paraná \\ E-mail: mimassuchin@gmail.com / ecervi 7@gmail.com
}

\begin{abstract}
Resumo
O artigo apresenta uma análise dos padrões de cobertura das eleições presidenciais de 2010 de dois veículos informativos com plataformas tecnológicas distintas, mas, de um mesmo grupo de comunicação. O jornal diário impresso $\mathrm{O}$ Estado de São Paulo (meio tradicional) e o portal informativo Estadao.com (novo meio). O objetivo é verificar quais similaridades e diferenças podem ser encontradas na tematização das eleições, enquadramentos e no tratamento dispensado aos três principais candidatos à presidência da república em 2010: Dilma Rousseff (PT), José Serra (PSDB) e Marina Silva (PV). Os resultados mostram que o

tema "campanha eleitoral" tende a aparecer menos no portal eletrônico do que no jornal impresso, enquanto o enquadramento temático tem maior presença no portal eletrônico. Ou seja, o veículo digital agenda menos, porém, com maior profundidade o tema eleitoral, ao contrário do que se poderia inferir inicialmente. O tratamento dos candidatos tende a ter mais valências positivas e negativas no portal do que no jornal. A hipótese explicativa para essa diferença é a de que no portal há interação contínua de leitores, que interferem nas rotinas produtivas de maneira mais decisiva do que no meio tradicional.
\end{abstract}

Palavras-chave: cobertura jornalística; eleições 2010; jornal diário; portal Estadão.

\begin{abstract}
This paper presents an analysis of the patterns of coverage of the 2010 presidential elections in two vehicles information with diferent tecnological platforms, but

the same group owner. The daily newspaper O Estado de São Paulo (traditional media printing) and webpage informational Estado.com (new media). The goal
\end{abstract}

Estudos em Comunicação no 20, 1-30 
is to see which similarities and diferences can be found in the thematization of elections, framing and treatment of three major candidates for presidente in 2010: Dilma Rousseff (PT), José Serra (PSDB) and Marina Silva (PV). The results show the theme "election campaign" tend to appear less on webpage. The digital vehicle schedule less, buth greather depth the issue. The treatment of candidates tends to be more positive and negative valences on webpage than in newspaper. A possible explanation for this difference is that on webpage there are continuous interaction with readers, wich inference with the production routines more decisively than in traditional media.

Keywords: coverage newspaper; presidential elections; 2010; Brazil.

\section{Introdução}

$\mathrm{O}$ artigo apresenta os resultados de um estudo que tem por objetivo fazer uma análise comparativa de duas plataformas tecnológicas distintas na cobertura das eleições presidenciais brasileiras de 2010 pelo grupo empresarial informativo "O Estado de São Paulo". Um dos maiores grupos noticiosos do Brasil, O Estado possui um dos jornais impressos diários de maior circulação no Brasil com média de circulação diária em 2011 de 263,04 mil exemplares (ver em www.ivcbrasil.org.br). Ao mesmo tempo, é um dos pioneiros na utilização de portais informativos em plataforma web para a circulação de informações. Além disso, os veículos do grupo Estadão mantêm uma cobertura permanente sobre a política brasileira, possuindo editorias e equipes específicas para as coberturas eleitorais nacionais (Informações oficiais em www.estadao.com.br). Por ser um jornal impresso de grande circulação e um dos pioneiros na produção de conteúdos jornalísticos em portais de notícias na internet, decidimos utilizar os veículos do grupo Estado como caso para ser analisado aqui.

Neste trabalho, faz-se uma análise da cobertura apresentada pelo jornal impresso O Estado de São Paulo e pelo portal Estadão.com durante os meses de julho a outubro de 2010. Os dados apresentados correspondem ao período de 5 de julho a 31 de outubro, incluindo primeiro e segundo turnos. O objetivo é, a partir da análise de conteúdo das coberturas, comparar padrões no tratamento dos principais candidatos à presidência da república em 2010, iden- 
tificando similaridades e diferenças na cobertura feita pelo impresso e pelo portal.

O estudo parte do princípio de que são os meios de comunicação que alimentam o debate público, principalmente em períodos eleitorais, que é o momento em que os indivíduos procuram mais informações que ajudem na definição do voto. Essa decisão depende de uma série de variáveis que interferem no processo de maneira direta e indireta. Na composição do conjunto de informações do eleitor são levadas em conta informações sobre das pesquisas de intenção de voto, a avaliação de governos anteriores, os partidos políticos, as conversas com familiares e amigos, o histórico dos candidatos, os conteúdos veiculados no Horário Gratuito Político Eleitoral (HGPE), o cenário econômico atual e, por fim, o posicionamento daqueles que fazem parte dos próprios meios de comunicação. A informação sobre política adquirida pelo público nos meios de comunicação tem um papel importante nesse processo, principalmente pelo agendamento do debate e pelo alcance que dos conteúdos disponibilizados.

Além disso, nas eleições mais recentes, principalmente a partir de 2002 no Brasil, é possível identificar a importância das novas tecnologias de comunicação e ferramentas de divulgação de informações políticas. Esses instrumentos foram sendo apropriados não apenas pelos candidatos, mas também pelas grandes empresas de comunicação que, além de manterem os jornais impressos, passaram a disputar espaço na rede mundial de computadores. Dessa forma, os sites passam a ser considerados como nova plataforma de informação política que, junto com a mídia impressa e a televisão, ajudam a agendar as discussões na esfera pública. E embora muitos sites e portais surjam dentro de grandes grupos de comunicação - como é o caso do Estadão.com ${ }^{1}$.

Este trabalho não pretende abordar a discussão levantada pela literatura sobre a disputa pela atenção do público entre mídia tradicional e on-line. Pelo contrário, considera-se aqui que por se tratar de veículos diferentes em plataformas com possibilidades comunicacionais distintas, há públicos e objetivos específicos para cada meio de comunicação. Isso é, inclusive, uma das possíveis hipóteses explicativas para as diferenças encontradas no conteúdo disponibilizado pelo jornal impresso "O Estado de São Paulo" e pelo portal

1. O conteúdo pode ser diferenciado de acordo com as características da nova plataforma, do público alvo e das rotinas produtivas próprias dos veículos on-line. 
"Estadão.com". Pretende-se aqui fazer uma análise de produção de conteúdos sobre campanhas eleitorais por meios de comunicação. A possibilidade de interação é o que explica as diferenças entre os conteúdos das novas plataformas em relação aos meios tradicionais. Produção de conteúdos compartilhada, em rede, com difusão em tempo real do acontecimento e comentários instantâneos que alteram os conteúdos são características típicas dos conteúdos jornalísticos dos portais informativos.

Para fazer as análises, este artigo mobiliza as seguintes variáveis: tematização, enquadramento dos textos informativos e valência das aparições dos três principais candidatos (Dilma Rousseff - PT, José Serra - PSDB e Marina Silva - PV) das eleições de 2010. A unidade de análise empírica é a citação do nome de pelo menos um dos candidatos nos textos ${ }^{2}$. Dentre as hipóteses de trabalho, parte-se do princípio de que a cobertura no portal foi mais fragmentada, apresentando enquadramentos factuais e menor presença do tema "política" devido as características de instantaneidade e fragmentação do próprio veículo. Uma hipótese alternativa é que ao tratar da cobertura dos candidatos especificamente, acredita-se que no portal Estadão.com existam mais valências positivas ou negativas aos candidatos do que na versão impressa da cobertura, onde deveria predominar a neutralidade em relação aos concorrentes. A partir daqui, o artigo apresenta uma discussão sobre os conceitos teóricos em embasam essa discussão sobre mídias tradicionais e novas tecnologias, assim como sobre a importância de informação política em períodos eleitorais. A fim de testar as hipóteses apresentadas, são analisados os dados empíricos sobre o período eleitoral de 2010. Por fim, apresentam-se as considerações finais.

\section{Informação política em período eleitoral}

A esfera pública, segundo Correia (2004) surge como uma esfera de identificação, tematização de problemas e discussão que, seguidamente, originam os processos de decisão política e de produção legislativa no interior do sis-

2. O trabalho empírico de coleta de dados foi realizado por pesquisadores dos grupos de pesquisa em Comunicação Política e Opinião Pública da Universidade Federal do Paraná e em Mídia, Política e Atores Sociais da Universidade Estadual de Ponta Grossa. Ao todo foram analisados 4672 textos, sendo 2184 no portal "Estadão.com" e 2488 no jornal impresso "O Estado de São Paulo". 
tema político. Como aponta Habermas (1964), este é um espaço intermediário entre a vida privada dos indivíduos e a esfera estatal, onde ocorrem as decisões políticas. É nesse espaço que os temas ganham status de público, ou seja, quando a coletividade passa a conhecer e formar opinião a respeito dos fatos (Dader, 1992), pois deixam de ser privados, principalmente quando recebem visibilidade dos meios de comunicação, que fazem parte desta esfera, atuando como instrumento para ampliar o debate. No caso das campanhas eleitorais de democracias em sociedades de massa, fica evidente a importância da mídia e da esfera pública de debate no processo de conhecimento dos candidatos e suas propostas para a decisão do voto.

Essa função da mídia em alimentar o debate público se torna ainda mais presente nas democracias representativas, onde a circulação de informação é a base para o debate, sendo que os meios de comunicação são os principais responsáveis pela difusão de temas de interesse público (McCombs e Shaw, 1972), sejam eles novos ou tradicionais. As notícias servem como suporte para o debate público, pois as pessoas precisam adquirir informações para pensar sobre o que não faz parte da sua experiência diária. A potencialidade da mídia fica em evidência com a teoria do agendamento temático que surge na década de 1960. Neste momento o processo de produção das notícias ganhou destaque nas pesquisas e a agenda midiática passou a ser tema de estudos ${ }^{3}$.

Dahl (2009) é um dos principais autores a estudar a democracia incluindo a presença de fontes diversificadas de informação como uma das condições/ exigências para o funcionamento desse tipo de regime. Isso significa, segundo Miguel (2000), um passo relevante, pois coloca o acesso à informação como um requisito básico. "Os cidadãos tem o direito de buscar fontes de informação diversificadas e independentes de outros cidadãos, especialistas, jornais, revistas, livros, telecomunicações e afins" (Dahl, 2009, p. 100). Dahl (1997; 2009) já apontava para a importância que a informação possui nesse tipo de governo, citando inclusive a presença dos meios de comunicação, pois eles ganham relevância por serem consideradas fontes de notícias para os indivíduos. Embora em outros períodos a relação entre mídia e política possa ficar

3. É preciso considerar que boa parte dos estudos sobre agendamento a partir de McCombs \& Shaw (1972) não levam em conta a influência dos novos meios, que apresentam como característica uma redução da capacidade de decisão dos produtores profissionais de notícias, transferindo-a aos demais participantes do debate que influenciam a construção coletiva dos conteúdos. 
mais distante, nos momentos de eleição a presença de fontes de informação são requisitos básicos para o processo decisório.

Seguindo analistas que consideram a variável informação como importante para a política, Manin (1995) diz que para que os governados, num governo representativo, possam formar opiniões sobre assuntos políticos é necessário que tenham acesso à informação política. Ou seja, trata-se de tornar públicas as decisões governamentais. Mesmo que a opinião pública seja resultado das discussões com outros atores em espaços públicos, os indivíduos utilizam os subsídios recebidos da mídia para formarem suas opiniões individuais sobre os temas sociais e políticos, como por exemplo, uma eleição. Ainda para Manin (1995), na "democracia do público", que emerge a partir da década de 70 em países com democracias consolidadas, os meios de comunicação apresentam um papel mais notável na relação com a esfera política. Além de poderem se aproximar do público por meio do rádio e da televisão (Manin, 1995).

Estudos sobre comunicação política que têm como objeto a produção jornalística partem do pressuposto que é esse conteúdo presente nas mais variadas plataformas - televisão, rádio, impresso, internet - que terá impacto no debate público. Como coloca Blanco (2000) quem gerencia inicialmente este espaço público são os jornalistas, ao lado dos pesquisadores e políticos. Porém, eles não têm o controle do resultado final do debate. Aumentando o leque de meios que produzem informações políticas nos últimos 20 anos viu-se a evolução de um novo espaço de comunicação política. Enquanto até o final do século XX apenas os meios tradicionais eram usados para noticiar a disputa eleitoral, no século XXI um novo espaço de debate político ganha destaque na esfera midiática. Trata-se da internet que também passou a ser utilizada como fonte de informação política a partir das eleições de 2002 (Aldé, 2004).

Quando os novos meios se estabeleceram e passaram a se destacar entre os meios de comunicação, possibilitando certa concorrência entre mídia online e tradicional, as pesquisas passaram a procurar diferenças entre eles. A primeira delas diz respeito ao processo de emissão, em que a comunicação deixa de ser de um para um, mas todos têm o potencial de comunicar para todos, principalmente por meio de comentários que podem ser feitos na seqüência da leitura e já ficam à disposição para os demais leitores. O processo de feedback também é contínuo e rápido, facilitando a interatividade. $\mathrm{Na}$ internet existe a facilidade de distribuição das informações que vão sendo 
disseminadas pela rede, onde todos se tornam emissores e provedores de informação (Aldé, 2005). Como ressalta Gomes (2004), na internet todo leitor é um potencial emissor, e todo receptor também pode ser emissor, além de todos poderem produzir conteúdo nos comentários, repassar e distribuir as informações disponibilizadas.

Nesse mesmo sentido, também há diferenças no processo produtivo. Os critérios de noticiabilidade e as variáveis que interferem na produção continuam existindo, no entanto a forma como elas agem e interferem é diferente, assim como o peso de cada uma delas nas decisões do que será ou não veiculado. Enquanto no jornalismo impresso as notícias vão sendo apuradas e modificadas antes de chegar ao leitor, no caso dos portais informativos online elas passam por um processo de checagem e modificação em tempo real (Alde, 2004). O leitor, por exemplo, vai acompanhando a inclusão de novas fontes e informações.

Nessa etapa dos estudos, a preocupação não é mais se a mídia tradicional será substituída pela mídia online, pois como mostraram Althaus e Tewksbury (2000), há uma tendência de quem acessa a internet ser o mesmo leitor de jornal impresso, não havendo então uma substituição

dos veículos. Agora a tentativa dos estudos é identificar as proximidades e divergências entre esses espaços, as diferenças no conteúdo, as alterações nos fatores que interferem no processo produtivo, entre outras questões comparativas. Seguindo essa lógica, Alde (2004) destaca um fenômeno que fica em evidência com a presença da internet juntamente com a televisão, o rádio e o jornal impresso, mostrando como é um trabalho em conjunto. Segundo ela, a internet contribui ainda mais para o fenômeno de "reflexividade" que seria a facilidade de reprodução de notícias entre eles, assim como a possibilidade de acompanhamento em tempo real das informações.

Trazendo essa discussão para a comunicação política é possível identificar algumas diferenças no processo de construção das notícias que tem relação com a esfera política. A primeira é que enquanto a internet acompanha de maneira instantânea a produção legislativa e executiva por ter mais espaço (Borges, 2007), os jornais precisam selecionar realmente os temas com algum fato significativo. Na internet o fator atualização se sobrepõe às demais variáveis que influenciam no processo de produção. É preciso que os portais estejam sempre atualizados, sendo que alguns fatos são totalmente descartados pelo jornal impresso (Borges, 2007). 
Outra marca distinta entre as informações política na internet e nos meios tradicionais diz respeito ao uso mais agressivo da rede, ou seja, esse espaço tem se destacado por apresentar mais ataques que depois são ignorados pela mídia tradicional. Se o tema - no caso de veículos de um mesmo grupo aparece na versão impressa do dia seguinte, ele recebe tratamento distinto daquele priorizado na página online. Segundo Aldé (2004), a internet apresenta mais ataque e agressividade ao tratar de assuntos políticos se comparado à mídia tradicional. Aldé (2004) cita exemplos que aconteceram nas eleições de 2002. Comparando as versões identifica-se que na rede, as notícias têm mais conteúdo agressivo e de ataque aos candidatos do que na mídia tradicional. Aqui, será possível observar como se dá a relação entre o portal e o jornal do grupo Estado, trabalhando com a variável valência para os candidatos citados no texto.

O trabalho feito por Borges (2007) se aproxima da proposta deste artigo. $\mathrm{O}$ autor analisou comparativamente os exemplares impressos dos jornais $\mathrm{O}$ Globo e Jornal do Brasil com as respectivas versões online. A diferença é que enquanto os dados que apresentamos aqui foram coletados em período eleitoral em que há uma lógica diferenciada para a produção jornalística, na pesquisa de Borges (2007) eles dizem respeito aos primeiros 100 dias de governo de Luiz Inácio Lula da Silva. No trabalho, o autor aponta as proximidades e divergências no conteúdo tentando explicar porque há alguns padrões similares nas coberturas e outras características distintas, como a maior negatividade na internet e a diferença entre os temas e enquadramentos do conteúdo publicado no jornal e nos portais online. Para o autor, isso se deve ao fato de que com o tempo os próprios grupos de comunicação foram percebendo que o jornalismo na rede deve ser diferente, adaptado ao meio e não fazendo somente uma transposição do veículo impresso. Como o jornalismo online nasceu dessa transposição, há características parecidas, mas a adaptação já foi responsável por algumas mudanças como no estilo e na apuração. Borges (2007) ressalta ainda que agora são os jornais que se apropriam de parte do conteúdo produzido na rede, pois tem como base as notícias produzidas no dia anterior.

A quantidade de notícias produzidas durante a campanha eleitoral é uma diferença importante em relação a períodos não-eleitorais. Para Borges (2007), que também identificou este fenômeno em sua pesquisa, trata-se de prioridades: enquanto no impresso a seleção é rigorosa, na rede a prioridade 
é o abastecimento rápido para atender o leitor. Mostrar que o portal é atualizado 24 horas por dia é primordial para o profissionalismo na era da internet. O autor identificou que cerca de $40 \%$ das notícias do portal é "aproveitada" pelo impresso, sendo que a maior parte é descartada num filtro formado por fatores como espaço, interesse do público, relevância do tema e outros. O enquadramento dado aos fatos também varia entre as plataformas tecnológicas. Embora seja o mesmo fato, a abordagem difere. Além disso, a análise feita por Borges (2007) identificou que há diminuição de personagens na notícia, como se na rede houvesse mais fontes citadas. Já nos jornais há prioridade por determinadas fontes, excluindo-se outras. Tentando se aproximar dessa proposta pretende-se identificar se há diferença entre as fontes utilizadas pelos dois tipos de veículos durante a campanha eleitoral.

De maneira geral, os estudos que incluem as novas tecnologias em disputas eleitorais ganharam evidência em três tipos de pesquisas principais em função do uso que se dá à internet: uma delas é pela mídia tradicional ou jornalistas independentes que se adaptaram à nova ferramenta para produzir conteúdo jornalístico e, supostamente, neutro e imparcial, seguindo a lógica dos meios tradicionais. Observando esse fenômeno se destacam os trabalhos de Aldé (2004) e Borges (2009). Numa outra vertente de estudos feitos por Dader (2009), Dader e Ayuso (2009), Kalnes (2009), Newell (2001) e Norris (2003) estão os trabalhos que analisam o uso que os partidos políticos fazem da internet, alimentando sites e redes sociais. Aqui são os partidos políticos que veem na internet uma ferramenta para divulgar as informações partidárias e ideológicas. Por último, também se percebe que as novas tecnologias vêm sendo utilizadas pelos próprios candidatos, de forma não institucional, para fazerem a própria campanha eleitoral. Eles se apropriam da nova ferramenta, criam sites e tentam manter contato com o eleitor também por meio dessa nova estratégia. Analisando esse fenômeno, podem ser citadas as pesquisas realizadas por Braga e Nicolás (2011), Montero (2009) e Redondo (2009).

Este artigo tem por objetivo contribuir com as pesquisas que se dedicam a estudar como a rede passou a ser usada pela mídia tradicional e identificar como isso ocorre. Portanto ele pode ser agrupado no leque de pesquisas que olham para a apropriação feita pelas empresas de comunicação e não pelos partidos e candidatos. Pretendendo dar um passo adiante na pesquisa, compara-se o conteúdo da web com o aquele produzido pela mídia tradicional. Isso se justifica pelo fato de serem duas plataformas diferentes de difusão 
de informação que trabalham com lógicas de produção distintas. Dessa forma, embora ambos sejam espaços de difusão de informação, é possível que haja divergências no conteúdo de acordo com as variáveis que influenciam a produção (Shoemaker e Vos, 2009). Isso será discutido de forma mais detalhada no próximo tópico, que trata das variáveis do processo de produção.

\section{Impacto dos critérios de produção jornalística no conteúdo político}

Tanto na produção jornalística feita pelos meios tradicionais quanto pela internet há fatores que influenciam no processo de escolha, tratamento e caracterização dos conteúdos publicados. É possível discutir os fatores levantados por Shoemaker e Vos (2009), Alsina (2010), Galtung e Ruge (1965), McCombs (2010) e Wolf (2009), observando como eles influenciam a construção das notícias. A escolha de temas, fontes, enquadramentos e tratamento aos candidatos são resultado do agir dos jornalistas, do peso das instituições econômicas e políticas, das rotinas produtivas, entre outros fatores. E são eles, junto com a caracterização do público, do contexto e das diferentes plataformas que explicam as diferenças encontradas.

Partindo do pressuposto de que as notícias não são "espelhos da realidade" (Alsina, 2009) como as primeiras teorias do jornalismo consideravam, Galtung e Ruge (1965) defendem que elas são determinadas culturalmente. Nessa mesma direção, Alsina (2009) afirma que o discurso jornalístico é um discurso social e está inserido num sistema produtivo. Dessa forma, passa-se a dar atenção para os fatores que influenciam esse sistema.

O primeiro processo é de seleção dos temas e acontecimentos feito por jornalistas. Segundo Wolf (2009) o processo de produção das notícias pode ser comparado a um funil dentro do qual se colocam inúmeros dados, mas apenas alguns conseguem ser filtrados. Dessa forma, meios de comunicação diferentes podem fazer seleção de temas distintos, embora possa predominar, em alguns momentos, um processo de agendamento entre os veículos. Normalmente cada empresa ou jornalista tem valores que definem, em parte, a noticiabilidade (Wolf, 2009). Os assuntos precisam chamar atenção dos produtores. No caso da disputa eleitoral, o tema por si só já tem características relevantes a partir de uma série de critérios, os quais são discutidos por diversos autores (Harcupl e O'Neill, 2001; Galtung \& Ruge, 1965; Silva, 2005; Wolf, 2009; Alsina, 2009) e que chamamos de valores-notícia. 
Além dos próprios fatos, o processo produtivo tem, ainda, uma série de influências como apontam Shoemaker e Vos (2009). De acordo com Aguiar (2007), a noticiabilidade de um acontecimento depende também dos jogos de poder e saber estabelecidos entre as empresas e a comunidade dos jornalistas e não apenas dos fatos em si, embora esse seja o primeiro passo. Os valores-notícia - relacionados diretamente ao fato - são os primeiros elementos necessários para discutir a presença de temas como assuntos potenciais para a cobertura jornalística.

Na perspectiva de Bourdieu (1997) esses valores-notícia podem ser considerados como "óculos especiais" que os jornalistas usam para identificar assuntos mais pertinentes à mídia. Como propõe o autor, os jornalistas "vêem de certa maneira as coisas que vêem" (Bourdieu, 1997: 25). Ou seja, é por meio desses critérios que os produtores selecionam os fatos, sendo que as características são compartilhadas por toda comunidade jornalística. Dessa forma, o que se pretende discutir aqui são quais critérios definidos na literatura podem ser considerados como as principais influências exercidas durante o processo de produção das notícias - isso, a partir da análise do resultado da produção e não das intenções dos produtores.

Há autores, como Silva (2005), que propõem uma sistematização dos critérios de noticiabilidade e os dividem em: i) critérios de noticiabilidade na origem do fato (seleção primária dos fatos / valores-notícia); ii) critérios de noticiabilidade no tratamento dos fatos (hierarquização, enquadramento, espaço, localização, etc); e iii) critérios de noticiabilidade na visão dos fatos.

Galtung e Ruge (1965) também propuseram uma série de critérios para explicar como os acontecimentos se transformam em notícia. Esses autores são referências para estudar esses valores, pois tentaram explicar porque alguns fatos se transformam em notícias e outros não (Harcupl \& O'Neill, 2001). Na perspectiva de Galtung e Ruge (1965) havia doze fatores que explicavam o conteúdo dos jornais.

Depois dessa sistematização inicial, outros estudos sugiram e dentre eles se destaca a proposta de Harcupl e O'Neill (2001), a partir de uma releitura dessas características. Os autores apresentaram critérios para notícias do dia a dia, pois o objetivo era observar como esses valores, que no trabalho de Galtung e Ruge (1995) eram pouco explicados e sistematizados a partir da 
realidade, poderiam ser aplicados atualmente ${ }^{4}$. Como ressaltaram Galtung e Ruge (1965), as ações da elite são mais importantes do que as atividades de outros atores sociais. Silva (2005) também destaca que notícias que envolvem o governo tem mais chances de ganhar atenção dos produtores, como é o caso de inaugurações, eleições, viagens e pronunciamentos. A magnitude e a relevância, fatores destacados por Harcup e O'Neill (2001) também explicam a presença das eleições como tema freqüento na cobertura no período estudado neste artigo. Wolf (2009) define outros critérios de noticiabilidade, citando o grau hierárquico dos indivíduos, o impacto, o interesse nacional, a quantidade de pessoas envolvidas pelos acontecimentos e, por fim, relevância e significância. Todas são características presentes no processo eleitoral.

Depois de definidos os fatos por esses critérios que envolvem a percepção dos jornalistas como diz Bourdieu (1997), é preciso fazer outras escolhas. Como propõe Silva (2005), trata-se de critérios de noticiabilidade no tratamento dos fatos. Neste segundo momento é preciso não apenas escolher, mas hierarquizar (Silva, 2005). Isso define as características com que os temas aparecem no jornal, interferindo e produzindo efeitos no processo de agendamento dos temas. Dentre os quesitos que influenciam no processo de agendamento estão: o espaço, a visibilidade, o enquadramento, as temáticas, a localização na página, etc. Esse segundo processo é importante, pois segundo McCombs (2009), o que influencia na saliência dos temas transferidos para o debate público é a forma com que ele aparece. As pessoas dão importância aos fatos a partir da quantidade de informação veiculada e da posição por ela ocupada. Os temas são tratados de forma desigual na sua apresentação ao público, já que uns são mais extensivos e outros severamente cortados (Weaver, McCombs e Spellman, 1975). No caso estudado aqui observa-se a presença do tema eleições e, por meio da variável valência, o tratamento aos candidatos. Segundo Weaver, McCombs e Spellman (1975) é a forma de valorização define grande parte do impacto no debate ${ }^{5}$.

4. São eles: poder de elite, surpresa, entretenimento, celebridade, fatos positivos e negativos, magnitude, relevância, agenda da comunicação e suíte. Vários desses explicam porque o tema 'eleição' já tem, por si só, elementos que chama a atenção dos jornalistas.

5. Embora normalmente os autores se refiram ao espaço ocupado pelas notícias nos impressos, é possível adaptar essa discussão para a maneira com que os meios de comunicação se referem aos candidatos. 
As diferenças nas características dos textos e no tratamento dado a cada candidato é resultado de escolhas. Além dos valores-notícias a seleção leva em consideração outros critérios analíticos, tais como os individuais, da redação, das instituições, da economia, da audiência, entre outros que foram enumerados por McCombs (2009) e Shomaker e Vos (2009), ou seja, são interferências internas e externas das redações que também ajudam no processo de produção. Como aponta Fog (2004), a produção feita pelos meios de comunicação é influenciada por inúmeros fatores, sendo que, para Rocha (2008), não são só os jornalistas os responsáveis, de fato, pela produção.

McCombs (2009), por exemplo, fala de três fatores, os quais ele considera como sendo os elementos-chave do processo produtivo: as fontes que fornecem informações, as interações e a influência dos veículos de comunicação entre si (agendamento intermídia) e a terceira, que são as normas sociais do jornalismo. O primeiro elemento apontado por McCombs (2009) são os atores que informam os jornalistas. Parte daquilo que sabemos origina-se em fontes oficiais e, principalmente, de assessorias de comunicação. Além das fontes de informação, os próprios meios exercem influência sobre os demais, ou seja, os veículos maiores são responsáveis em agendar os locais e regionais. E as agências de notícias também possuem forte relação com a agenda da mídia. Já a terceira variável apontada por McCombs (2009) são as normas e tradições do jornalismo. Isso pode explicar as diferenças na visibilidade que de um tema ou candidato recebe em um veículo e em outro.

Seguindo essa discussão, Shoemaker e Vos (2009), por meio da Teoria do Gatekeeper, fazem um detalhamento sobre os fatores que interferem na escolha e tratamento dos temas, os quais são usados aqui para explicar as diferenças na aparição e tratamento dado aos candidatos em período eleitoral. Inicialmente partia-se do princípio de que as notícias eram selecionadas de acordo com as escolhas dos jornalistas (gatekeeper). Mas hoje tais escolhas não se relacionam somente aos critérios pessoais dos profissionais e sim, com outros fatores externos ao jornalista. É o caso das rotinas dos próprios veículos de comunicação. Shoemaker e Vos (2009) explicam que esse nível seria responsável pela padronização do veículo. Os jornalistas articulam-se nas rotinas do jornal, ou seja, a partir da internalização de valores por meio do processo de socialização que, segundo Ramírez (1992), é mais relevante do que as escolhas pessoais do jornalista. 
A discussão avança e elenca as próprias organizações midiáticas como fatores que incidem na escolha das notícias (não apenas escolha como um processo simples, mas de direcionamento, enquadramento, angulação, etc.). Nessa instância os autores chamam atenção para a influência das políticas organizacionais no conteúdo dos veículos, processo que pode ser mais bem visualizado quando discutidas a presença e valência das notícias relacionadas a determinados candidatos. Para além desses fatores relacionados à instituição, há ainda os constrangimentos externos, os quais são chamados por Rocha (2008) como "as pressões de fora", sendo que podem ser, por exemplo, comerciais e políticas, delimitando a autonomia e independência da mídia (Azevedo, 2001). Os dois últimos níveis que Shoemaker e Vos (2009) propõe são os fatores externos, como instituições e sistema social, no qual o veículo está inserido e que, segundo Ramírez (1992), é determinante no processo produtivo. Os meios de comunicação fazem parte de num sistema social com outras instituições, as quais, segundo Shoemaker e Vos (2009), afetam o processo de produção jornalística.

As organizações noticiosas são influenciadas por fatores econômicos (mercado dita o que dever se considerado notícia para aumentar as vendas e consequentemente os lucros do veículo), das audiências (interesse do público), dos anunciantes, do governo, grupos de interesse, etc. Estas são instituições externas que, por estarem próximas da mídia, operam sobre seu conteúdo indiretamente por meio de normas e regras também internalizadas, pois, os jornalistas assumem as demandas e valores como sendo os seus. Segundo Shoemaker e Vos (2009), é o mercado que define o conteúdo, ou seja, são as demandas da audiência que são produzidas pelos jornais. Isso pode, por exemplo, explicar a possível entrada de temas no jornal.

A construção da realidade produzida pelas empresas jornalísticas depende, dessa forma, da postura do veículo, da sua relação com o poder político e da sua inserção na economia (Aruguete, 2005), pois o tipo de mercado condiciona o trabalho dos jornalistas (Ramírez, 1992). Para Rocha (2008), é a desigualdade no poder de definir a agenda midiática, existente na relação entre os jornalistas, a elite política e do mercado que fazem desses últimos "agentes sociais como definidores primários da notícia, enquanto os profissionais da imprensa figuram apenas como definidores secundários" (Rocha, 2008, p. 49). E além desses critérios de tratamento, que determinam as características das notícias nas páginas dos jornais, há também os critérios de noticiabilidade 
na visão dos fatos, que dizem respeito às escolhas que levam em consideração os fundamentos éticos, filosóficos e epistemológicos do jornalismo, que compreende os conceitos de verdade, objetividade, interesse público e imparcialidade (Silva, 2005).

No caso deste estudo, por se tratar de plataformas diferentes, possivelmente há diferença também no público que acessa esses dois veículos o que tem impacto nas possíveis distinções no conteúdo. Como a produção leva em consideração o público a que ela se destina (Borges, 2007), acredita-se que isso também seja um fator que interfira no processo de construção das notícias, mesmo em veículos pertencentes ao mesmo grupo de comunicação.

\section{Similaridades e diferenças entre mídia tradicional e os novos portais in- formativos}

Neste artigo analisamos as variáveis "temática", "enquadramento", "valência", "quantidade de entradas", "tipos de fontes" e "visibilidade dos candidatos". A pesquisa utiliza a metodologia quantitativa de análise de conteúdo. A unidade de seleção é o nome do candidato, ou seja, são analisados todos os textos informativos que citam o nome de pelo menos um dos candidatos à presidência da república em 2010. Conforme Bauer (2003), por meio desse método é possível observar tendências, padrões, quantidades, qualidades e, principalmente, distinções entre casos analisados. Na análise utiliza-se um conjunto de 4672 entradas, somando as notícias publicadas no site e no impresso, ou seja, textos que citam pelo menos um dos candidatos à presidência. A variável 'tema' é composta pelas categorias: campanha eleitoral, políticoinstitucional, economia, infraestrutura, entre outras. Cada uma delas indica o assunto predominante de cada texto. As categorias da análise sempre são mutuamente excludentes. Cada texto é enquadrado em apenas uma categoria.

Para analisar o enquadramento, adaptamos a categorização proposta por Porto (2005), que tem define enquadramentos como "os ângulos das notícias". É aplicada exclusivamente a textos informativos - nota e reportagens - e possui as categorias: personalista (de interesse no indivíduo), episódico (ênfase em eventos/acontecimentos), temático (foco nos temas para além da necessidade da existência de um fato específico) e corrida de cavalo (disputa da eleição). 
A valência é categorizada em positiva, negativa, equilibrada e neutra, sendo que essa categorização é utilizada para avaliar o tratamento dado pelos jornais aos candidatos ${ }^{6}$. Observa-se ainda a quantidade de citações dos candidatos por meio da presença ou ausência dos nomes no título, o espaço de maior visibilidade do texto. Por fim, trabalha-se também com os tipos de fontes utilizadas nos textos.

Os primeiros resultados indicam uma maior presença dos nomes dos candidatos na versão impressa do que no portal do "Estadão", o que dá indícios de que o impresso deu mais atenção à cobertura política em período eleitoral do que o meio eletrônico. Foram 2488 textos citando pelo menos um dos concorrentes no jornal, contra 2184 no portal entre os meses de julho e outubro de 2010. Partindo-se da idéia de mais espaço disponível, esperava-se uma cobertura mais extensa na plataforma digital. No entanto os resultados indicaram o contrário. No caso das eleições de 2010, pelo menos, o fato de a internet ter mais espaço não significou maior cobertura sobre os candidatos. Os espaços definidos e limitados nas páginas dos cadernos de política foram maiores para a cobertura dos candidatos à presidência do que as páginas digitais do portal eletrônico em 2010. Pode ser, obviamente, que isso ocorra com outros temas e não com esse estudado.

Já em relação aos temas da cobertura eleitoral, poucas diferenças proporcionais foram percebidas entre os dois veículos, como mostra a última coluna da tabela 1 a seguir. A maior delas foi uma proporção de 20,98 pontos percentuais a menos do tema "campanha eleitoral" no portal em relação ao jornal impresso, ou seja, temas relacionados com a corrida eleitoral, com a agenda dos candidatos ou com a disputa em si, como o texto "Campanha eleitoral começa oficialmente nesta terça-feira. Cada um escolheu uma cidade como ponto de partida: Dilma estará em Porto Alegre, Serra, em Curitiba, e Marina, em São Paulo" (Estadão.com - 06/07/2010), ganharam menos destaque no portal, sendo muito mais recorrente no impresso. Embora o tema tenha predominado nas duas coberturas, ele fica muito mais evidente naquela feita pelo impresso. Isso é o que pode explicar a maior presença dos candidatos no impresso em relação ao meio digital. Como o portal tratou menos do tema

6. A primeira vez que a categoria valência foi utilizada no Brasil para esse tipo de pesquisa de conteúdo em jornais foi a partir de uma adaptação feita pela equipe do Doxa/Iuperj, coordenada pelo prof. Marcus Figueiredo, para as eleições de 1998. Desde então várias outras pesquisas utilizaram essas categorias como base para suas análises. 
New informative platforms and traditional media: synergy or antagonism? 17

campanha eleitoral e ele foi o predominante no período, o impresso acaba destinando mais espaço geral aos candidatos.

Tabela 1. Presença de temas nas coberturas do jornal e portal Estadão

\begin{tabular}{|c|c|c|c|c|c|c|c|c|}
\hline \multirow{2}{*}{ Tema } & \multicolumn{2}{|c|}{ Portal } & & \multicolumn{2}{|c|}{ Impresso } & \multirow{2}{*}{ Total } & \multirow{2}{*}{ Méd. \% ${ }^{\mathrm{b}}$} & \multirow{2}{*}{ Dif. $^{b}$} \\
\hline & $\mathrm{N}$ & $\%$ Tot. & \% Vál. & $\mathrm{N}$ & $\%$ Tot. & & & \\
\hline Campanha Eleitoral & 1020 & 46,7 & 60,1 & 2142 & 86,1 & 3162 & 73,1 & $-26,0$ \\
\hline Político-institucional & 136 & 6,2 & 8,0 & 134 & 5,4 & 270 & 6,7 & 2,6 \\
\hline Economia & 42 & 1,9 & 2,5 & 38 & 1,5 & 80 & 2,0 & 1,0 \\
\hline Política Social & 52 & 2,4 & 3,1 & 25 & 1,0 & 77 & 2,0 & 2,1 \\
\hline Infraest. e meio ambiente & 44 & 2,0 & 2,6 & 10 & 0,4 & 54 & 1,5 & 2,2 \\
\hline Violência e segurança & 17 & 0,8 & 1,0 & 4 & 0,2 & 21 & 0,6 & 0,8 \\
\hline Ético-moral & 222 & 10,2 & 13,1 & 72 & 2,9 & 294 & 8,0 & 10,2 \\
\hline Política para Esporte & 2 & 0,1 & 0,1 & 4 & 0,2 & 6 & 0,1 & $-0,1$ \\
\hline Cultura/variedades & 8 & 0,4 & 0,5 & 2 & 0,1 & 10 & 0,3 & 0,4 \\
\hline Política Est./Nac./inter. & 72 & 3,3 & 4,2 & 12 & 0,5 & 84 & 2,3 & 3,7 \\
\hline Outros temas & 569 & 3,8 & 4,9 & 45 & 1,8 & 614 & 3,3 & 3,1 \\
\hline Imagens $^{\mathrm{a}}$ & & 22,3 & & & & & & \\
\hline Total & 2184 & 100,0 & & 2488 & 100,0 & 4672 & 100,00 & \\
\hline
\end{tabular}

${ }^{a}$ A variável Tema no portal recebeu as categorias de imagens (do candidato, do governo e dos eleitores) que não existe na tematização do veículo impresso. Por esse motivo as categorias de imagens foram retiradas dos percentuais comparativos entre os dois veículos. Para comparação com impresso deve-se usar o \% válido, que desconsidera os casos das categorias de imagem.

${ }^{\mathrm{b}}$ Cálculo das diferenças é entre \% válido do portal e \% total do impresso, o que exclui os percentuais das categorias imagens, presente apenas no portal.

Fonte: Grupo de Pesquisa UFPR/UEPG

O tema que contou com a maior diferença proporcional em favor do portal foi "ético-moral", com 10,2 pontos percentuais a mais em relação ao jornal impresso. Trata-se de textos, por exemplo, envolvendo corrupção, ilegalidade na campanha, acusações entre candidatos, entre outros assuntos em que o foco do texto está nos valores. Exemplos de textos dessa categoria são "Antes do prazo legal, Índio já pede votos na Internet. Vice de Serra usou o Twitter para pedir votos; TRE só autoriza propaganda na rede após 5 de julho" (Estadão.com - 05/07/2010) e "Presidente não precisa ser corrupto, diz Marina Silva" (Estadão.com - 19/07/2010). Ou seja, o portal tratou mais de questões 
morais e menos do cotidiano da campanha eleitoral, como fica claro na diferença de $-26,0$ pontos percentuais entre as presenças do tema campanha no portal e no impresso.

Uma possível explicação para a presença desses assuntos no portal e não no impresso é que eles eram mais polêmicos e muitas vezes ofereciam imagens e propagandas negativas do candidato, o que segundo Aldé (2004) tende a ser uma característica da rede e não da mídia tradicional. O que se percebe ainda é que diferente do impresso em que os temas são mais comuns, encaixando-se nas categorias já delineadas pela pesquisa, no caso do portal há notícias em que os temas são menos comuns, sendo então caracterizada como outra. Há presença de candidatos em textos não usuais, como por exemplo, "Câmara Municipal dá título de cidadã paulistana a Dilma" (25-08-2010). Ou seja, há maior ligação de candidatos com assuntos episódicos e pouco ligados à campanha no portal, diferente do impresso em que predominam, em $86,1 \%$ das entradas, temas restritos ao andamento do pleito. Excetuando-se essas diferenças, de maneira geral, portal e jornal impresso deram a mesma tematização para a cobertura eleitoral de 2010. Em linhas gerais, o resultado indica que o portal se afasta mais da cobertura temática informativa e isenta que defende o jornalismo comercial tradicional para aproximar-se de um padrão de textos mais interpretativos e sobre temais mais polêmicos, não apenas a agenda da campanha. Em todos os demais temas a diferença percentual entre o portal e o impresso ficou abaixo dos 4 pontos percentuais.

Já sobre a distribuição da cobertura eleitoral ao longo dos três meses de campanha percebe-se que antes do primeiro turno os veículos apresentaram tendências parecidas. Momentos de pico similares o que equivale à cobertura das mesmas questões pontuais de campanha, como os debates e a apresentação dos resultados de pesquisas de opinião. Mas como pode-se perceber, as diferenças aparecem na cobertura do segundo turno. Para facilitar a leitura das curvas de tendência, foram plotados os logaritmos ${ }^{7}$ dos números de textos diários com citação de candidatos no gráfico 1 .

7. Como as variações diárias do número de textos são muito grandes, isso dificulta a produção de indicadores confiáveis. No caso do jornal, a média diária é de 20,3 textos enquanto o desvio padrão fica em 10,9. No caso do portal a variação é ainda maior. O número médio de textos por dia foi de 19,8, com um desvio padrão de 17,0. Em ambos os casos, após a transformação logarítmica a média ficou pouco baixo de 2,8 . 
Gráfico 1. Número de entradas ao longo do tempo nos dois veículos

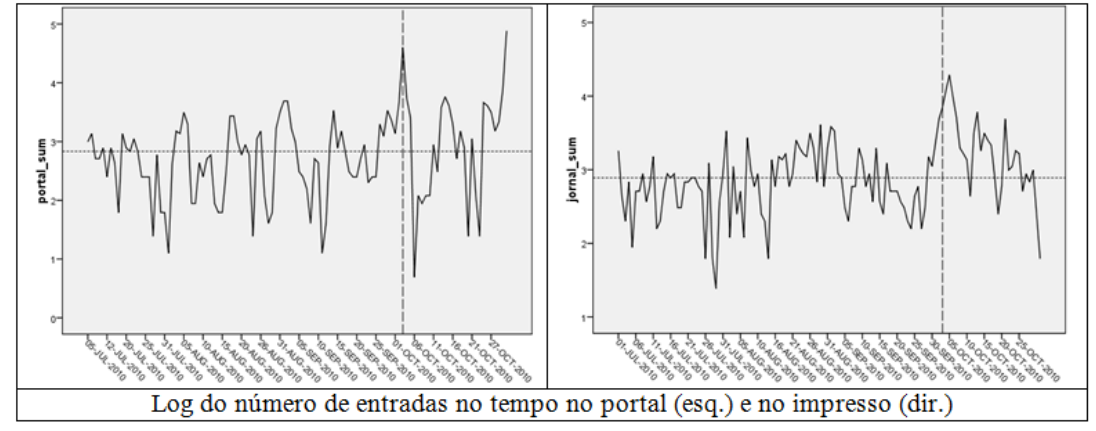

Fonte: Grupo de Pesquisa UFPR/UEPG

É possível perceber que as duas imagens variam em torno da mediana do $\log$ em todo o primeiro turno. Já no segundo turno as variações aumentam. Outra diferença é que no portal há uma queda no início do segundo turno, para depois a tendência se inverter para crescente. Já no jornal impresso, durante todo o segundo turno é possível notar uma tendência de queda no número de textos com citação de candidatos.

Em uma análise de regressão temporal as duas curvas apresentam resultados muito similares, indicando uma variação com baixa tendência temporal. Para as citações diárias de candidatos no portal Estadão, o r2 do modelo foi 0,100 (sig. 0,001). Já para as variações diárias das aparições de candidatos no jornal impresso, o r2 do modelo ficou em r2 0,104 (sig. 0,000). Ambos aumentam significativamente a produção na última semana do primeiro turno. Enquanto o pico da cobertura do portal foi no dia das eleições, com a cobertura minuto a minuto, no impresso o pico foi nos dias posteriores à eleição, com a cobertura do dia 3 de outubro. Essa diferença entre ambos se deve às alterações entre as plataformas, pois enquanto o portal publicou as notícias no dia da eleição, o jornal selecionou durante o dia as mais importantes e apresentou no dia seguinte.

Diferença maior ainda observa-se na cobertura do segundo turno, pois embora ambos tenham acompanhado as pesquisas e debates, a cobertura do dia da eleição foi residual no impresso em comparação com o portal que apresentou outro pico na cobertura eleitoral do período. Portanto, ao observar a cobertura ao longo do tempo sobre os candidatos, percebe-se uma tendência 
de acompanhamento parecido dos fatos da campanha, mas diferente nos dias da votação, tendo lógicas distintas de cobertura mais em função das características diferentes das plataformas tecnológicas do que dos interesses editoriais e econômicos do grupo a que pertencem os veículos.

Com respeito aos enquadramentos na cobertura geral, algumas diferenças surpreendem. Os dados contrariam nossa hipótese inicial de que na web os textos seriam mais fragmentados, podendo ser enquadrados majoritariamente como episódicos. Eles indicam que o tipo de enquadramento com maior presença no portal em comparação com o jornal impresso é o "temático", com diferença de 9,87 pontos percentuais. O enquadramento "episódico", que se imaginava que seria predominante na rede, tem a pior relação comparativa com o jornal impresso, com $-7,33$ pontos percentuais. A tabela 2 a seguir também apresenta os valores dos resíduos padronizados para o teste de independência aplicado aos dois veículos. Apenas os resíduos acima de 1,96 indicam uma tendência de encontrar de maneira consistente mais casos de determinada categoria de enquadramento em um veículo quando comparado ao outro.

Tabela 2. Enquadramentos dos textos informativos no jornal e portal Estadão

\begin{tabular}{l|r|r|r|r|r|r|r}
\hline \multirow{2}{*}{ Enquadramento } & \multicolumn{2}{|c|}{ Portal } & \multicolumn{2}{|c|}{ Jornal } & \multirow{2}{*}{ Total } & Média \% & \multirow{2}{*}{ Dif. } \\
\cline { 2 - 5 } & \multicolumn{1}{c|}{$\mathrm{N}$} & \multicolumn{1}{c|}{$\%$} & $\mathrm{~N}$ & \multicolumn{1}{c}{$\%$} & & & \\
\hline $\begin{array}{l}\text { Corrida de cavalos } \\
\text { (resíduo padronizado) }\end{array}$ & $\begin{array}{r}181 \\
(-3,639)\end{array}$ & 8,3 & $\begin{array}{r}188 \\
(4,877)\end{array}$ & 15,5 & 369 & 10,85 & $-2,57$ \\
\hline $\begin{array}{l}\text { Personalista } \\
\text { (resíduo padronizado) }\end{array}$ & $\begin{array}{r}48 \\
(0,068)\end{array}$ & 2,2 & 26 & 2,1 & 74 & 2,18 & 0,02 \\
\hline $\begin{array}{l}\text { Temático } \\
\text { (resíduo padronizado) }\end{array}$ & $\begin{array}{r}1192 \\
(6,901)\end{array}$ & $\mathbf{5 4 , 6}$ & $\begin{array}{r}328 \\
(-9,248)\end{array}$ & 27,0 & 1520 & 44,71 & $\mathbf{9 , 8 7}$ \\
\hline $\begin{array}{l}\text { Episódico } \\
\text { (resíduo padronizado) }\end{array}$ & $\begin{array}{r}763 \\
(-5,268)\end{array}$ & 34,9 & $\begin{array}{r}674 \\
(7,060)\end{array}$ & $\mathbf{5 5 , 4}$ & 1437 & 42,26 & $\mathbf{- 7 , 3 3}$ \\
\hline Total & 2184 & 100,0 & 1216 & 100,0 & 3400 & 100,00 & \\
\hline
\end{tabular}

Fonte: Grupo de Pesquisa UFPR/UEPG

Em ambos os veículos a cobertura personalista é residual e muito parecida, o que significa que os textos não focam nos personagens, mas sim na disputa eleitoral. Os resíduos padronizados para as duas categorias complementam a informação. Eles ficam abaixo do limite de 1,96, portanto, não se concentram em nenhum dos veículos. Corrida de cavalo tem uma diferença 
menor entre ambos no que diz respeito aos números absolutos, mas apresenta uma participação percentual maior no impresso. Esses são textos que tratam, principalmente, de pesquisas eleitorais e disputa de votos, indicando quem está à frente. Os resíduos reforçam a informação anterior (tab. 1) de que o espaço majoritário para apresentação dos resultados de pesquisas eleitorais foi no impresso e não no portal. Enquanto o resíduo para o impresso ficou em $+4,877$, no portal ele foi de $-3,639$. Ou seja, há chances negativas de encontrar esse enquadramento no portal do Estadão e chances positivas no jornal impresso do grupo.

O principal achado que contraria a hipótese de textos episódicos na internet e temáticos no jornal pode ser explicado pelo fato de não haver limitação de caracteres na rede, os textos sobre campanha eleitoral discutiram mais o tema para além do fato que gerou a notícia. E de qualquer maneira, a presença de textos temáticos tem característica positiva já que os fatos não são tratados de maneira isolada, pois como coloca Porto (2004) há um contexto analítico mais geral.

Embora no jornal não haja predomínio do enquadramento temático, imaginava-se que na internet pela necessidade de produção instantânea, como apontou Borges (2007), a presença desse tipo de enquadramento seria ainda menor. No entanto, possivelmente a ausência de limitação de espaço tenha permitido a presença de textos temáticos, envolvendo discussão de políticas públicas, como mostra o exemplo "Serra prepara plano com '100 ações para mudar o Brasil"” (Estadão.com - 5/07/2010). No entanto, trata-se somente que uma análise exploratória que ainda precisa encontrar outras explicações para além do tamanho dos textos para explicar esse resultado que contraria a hipótese inicial. $\mathrm{Na}$ análise em questão, o enquadramento temático é o que apresenta os maiores resíduos padronizados dos dois veículos. O coeficiente é de $+6,9$ para o portal e de $-9,2$ para o impresso, portanto, há mais chances de encontrar textos com enquadramento temático no portal e menos no impresso. Os coeficientes de resíduos padronizados para a categoria "episódico" também são altos para os dois veículos, porém, com sinais trocados. Há mais chances de encontrar textos episódicos no impresso do que no portal.

No que diz respeito às valências dos candidatos nas duas plataformas tecnológicas, de maneira geral, Dilma Rousseff (PT) tem mais aparições positivas e negativas que os demais - na soma do portal e impresso. Marina Silva (PV) tem o maior percentual médio de aparições neutras. José Serra (PSDB) 
fica entre as duas candidatas em termos de valências positivas e negativas. Em relação às valências comparadas entre os veículos, Dilma teve mais cobertura positiva e equilibrada no portal do que no jornal impresso, pouco mais de três pontos percentuais em favor da plataforma eletrônica. No jornal predominaram as valências neutra e negativa. Dilma, desta forma, teve uma cobertura mais favorável à sua imagem no portal do que no impresso, lembrando que ela apareceu em número próximo de textos nas duas plataformas.

Destaca-se que apenas para Dilma o impresso teve mais valências negativas que o portal. Nos demais, a valência negativa é quase irrisória no impresso, destacando-se mais no portal. Esses dados apresentados aqui vão ao encontro da discussão feita por Aldé (2005) e Borges (2007) de que na internet há tendência da propaganda negativa. Segundo os autores isso pode ser explicado pela rotina menos controlada da internet em relação ao jornal, sendo que os jornalistas, cada qual ao seu modo, produzem sem uma presença constante da força institucional e editorial para os textos neutros e fazer uma cobertura equilibrada em todos os candidatos.

Tabela 3. Comparação das valências de citações dos principais candidatos

\begin{tabular}{|c|c|c|c|c|c|c|c|c|}
\hline \multirow[b]{2}{*}{ Candidato } & \multirow[b]{2}{*}{ Valência } & \multicolumn{2}{|c|}{ Portal } & \multicolumn{2}{|c|}{ Jornal } & \multirow{2}{*}{$\begin{array}{c}\mathrm{N} \\
\text { Total }\end{array}$} & \multirow{2}{*}{$\begin{array}{c}\% \\
\text { Total }\end{array}$} & \multirow{2}{*}{$\begin{array}{c}\text { Dif. } \\
\text { Portal }\end{array}$} \\
\hline & & $\mathrm{N}$ & $\%$ & $\mathrm{~N}$ & $\%$ & & & \\
\hline \multirow{5}{*}{ DILMA } & Positiva & 185 & 10,4 & 72 & 4,1 & 257 & 7,22 & 3,16 \\
\hline & Negativa & 151 & 8,5 & 230 & 12,9 & 381 & 10,70 & $-2,23$ \\
\hline & Neutra & 1275 & 71,5 & 1436 & 80,8 & 2711 & 76,15 & $-4,64$ \\
\hline & Equilibrada & 172 & 9,6 & 39 & 2,2 & 211 & 5,93 & 3,72 \\
\hline & Total & 1783 & 100,0 & 1777 & 100,0 & 3560 & 100,00 & \\
\hline \multirow{5}{*}{ SERRA } & Positiva & 133 & 8,2 & 7 & 0,7 & 140 & 5,39 & 2,85 \\
\hline & Negativa & 131 & 8,1 & 8 & 0,8 & 139 & 5,35 & 2,76 \\
\hline & Neutra & 1181 & 73,1 & 963 & 98,0 & 2144 & 82,53 & $-9,40$ \\
\hline & Equilibrada & 170 & 10,5 & 5 & 0,5 & 175 & 6,74 & 3,79 \\
\hline & Total & 1615 & 100,0 & 983 & 100,0 & 2598 & 100,00 & \\
\hline \multirow{5}{*}{ MARINA } & Positiva & 74 & 11,1 & 13 & 1,1 & 87 & 4,75 & 6,34 \\
\hline & Negativa & 13 & 1,9 & 13 & 1,1 & 26 & 1,42 & 0,53 \\
\hline & Neutra & 538 & 80,7 & 1135 & 97,5 & 1673 & 91,37 & $-10,71$ \\
\hline & Equilibrada & 42 & 6,3 & 3 & 0,3 & 45 & 2,46 & 3,84 \\
\hline & Total & 667 & 100,0 & 1164 & 100,0 & 1831 & 100,00 & \\
\hline
\end{tabular}

Fonte: Grupo de Pesquisa UFPR/UEPG 
New informative platforms and traditional media: synergy or antagonism? 23

Para o candidato Serra, apenas a valência neutra apresentou maior presença no impresso. Todas as demais categorias tenderam a aparecer mais no portal. Enquanto no impresso a valência positiva teve menos de $1 \%$ dos textos, no portal estão em mais de $8 \%$. As valências para Marina Silva (PV) seguiram a mesma tendência de Serra, em que há tendência de positiva, negativa e equilibrada no portal, sendo que elas quase não apareceram no jornal. Dessa forma, exceto para o caso de textos negativos para Dilma que ficou mais evidente no impresso, percebe-se claramente a tendência para presença de valências nas notícias do portal em relação ao jornal em que elas estão quase ausentes. E de modo geral, mesmo no caso de Dilma, o percentual de neutralidade é maior no impresso do que no jornal, confirmando que ao comparar as duas plataformas nas eleições de 2010, percebe-se a tendência da produção seguir a literatura sobre campanha mais imparcial na internet.

Até aqui se percebe que a cobertura do portal e do jornal tende a ficar mais próxima nos quesitos temática e distribuição ao longo do tempo, apresentando maiores diferenciações quanto ao enquadramento, à presença de valências e de visibilidade nos títulos. Antes de finalizar, apresentam-se dados de outra variável com o objetivo de dialogar com os "achados" de Borges (2007). Segundo o autor na cobertura impressa há uma tendência de diminuir a quantidade de fontes e com isso as segundas e terceiras fontes ficam de fora da cobertura impressa, tornando as notícias menos amplas e com apenas um ponto de vista, diminuindo o debate que anteriormente era possibilitado na rede. Para o autor, se um texto é aproveitado no dia seguinte para a produção impressa do jornal, ele é severamente cortado, principalmente no que diz respeito aos atores que aparecem na cobertura. Essa tendência foi percebida na cobertura comparativa feita pelo autor em 2002 e pretende-se verificar como ela ocorreu em 2010, no caso do Estadão. 
Tabela 4. Comparação entre as fontes utilizadas no impresso e no portal

\begin{tabular}{l|c|c|c|c|c}
\hline \multirow{2}{*}{ Fontes } & \multicolumn{2}{|c|}{ Portal } & \multicolumn{2}{c|}{ Jornal } & \multirow{2}{*}{ Dif. } \\
\cline { 2 - 5 } & $\mathrm{N}$ & $\%$ & $\mathrm{~N}$ & $\%$ & \\
\hline Lobistas & 326 & $\mathbf{1 4 , 9}$ & 240 & 9,6 & 5,3 \\
\hline Especialistas & 84 & $\mathbf{3 , 8}$ & 71 & 2,9 & 0,9 \\
\hline $\begin{array}{l}\text { Cidadão individualizado/ } \\
\text { Portador de temas marginais }\end{array}$ & 75 & $\mathbf{3 , 4}$ & 12 & 0,4 & 3,0 \\
\hline Jornalista & 1691 & 77,4 & 2015 & $\mathbf{8 1 , 0}$ & $-3,6$ \\
\hline Outro & 8 & 0,4 & 150 & $\mathbf{6 , 0}$ & $-5,6$ \\
\hline Total & 2184 & 100,0 & 2488 & 100,0 & \\
\hline
\end{tabular}

Fonte: Grupo de Pesquisa UFPR/UEPG

Essa discussão está relacionada com a qualidade e diversidade da informação colocada à disposição dos eleitores. Para além da presença ou ausência de informações, a pluralidade de ideias e a possibilidade de debate são centrais para o processo de compreensão do tema e da decisão do voto, partindo-se do pressuposto que as informações vindas dos meios de comunicação - novos ou tradicionais - contribuem para fomentar o debate na esfera pública. Seguindo a literatura já existente, percebe-se uma diminuição na presença de fontes no jornal, aumentando o número de textos em que o conteúdo se baseia apenas no relato do repórter.

Na sequência percebe a diminuição de todos os tipos de fontes - lobistas, especialistas e cidadão - na cobertura impressa. Dentre os diferentes tipos, predominam, conforme já está explicito na literatura (Habermas, 2006; Serrano, 1999), os atores denominados lobistas. Isso ocorre em ambas plataformas, no entanto, como o número de cidadãos comuns já é restrito, no impresso ele fica ainda mais reduzido, se aproximando de zero. Portanto, esses dados indicam outra diferença na cobertura política feita pelos novos e velhos meios que é a diminuição do número de fontes nas notícias. Para cada dez fontes citadas no impresso, há nove no portal. Para organizar a conclusão das análises a seguir, o quadro 1 abaixo indica os principais achados para cada uma das variáveis incluídas no estudo, comparando os dois veículos de informação do grupo Estado. 
New informative platforms and traditional media: synergy or antagonism? 25

Quadro 1. Síntese da comparação das variáveis nos dois veículos

\begin{tabular}{|c|c|c|}
\hline Variável & Portal & Jornal \\
\hline Tematização & $\begin{array}{l}\text { Pautado pela discussão temática, } \\
\text { principalmente relacionada a } \\
\text { questões éticas e posicionamentos } \\
\text { morais. }\end{array}$ & $\begin{array}{l}\text { Pautado pelo relato factual do } \\
\text { cotidiano da campanha e do dia-a- } \\
\text { dia da corrida eleitoral, } \\
\text { principalmente a partir da } \\
\text { publicação de pesquisas de intenção } \\
\text { de voto. }\end{array}$ \\
\hline Série temporal & $\begin{array}{l}\text { Primeiro turno cobertura com } \\
\text { pouca variação em torno da média. } \\
\text { No segundo turno há tendência de } \\
\text { crescimento no número de textos. }\end{array}$ & $\begin{array}{l}\text { Primeiro turno cobertura } \\
\text { homogênea em torno da média. No } \\
\text { segundo turno há uma tendência de } \\
\text { queda no número de textos. }\end{array}$ \\
\hline $\begin{array}{c}\text { Enquadramentos } \\
\text { das notícias }\end{array}$ & $\begin{array}{l}\text { Predomínio de enquadramento } \\
\text { temático, com tendência negativa } \\
\text { de ocorrência do enquadramento } \\
\text { episódico e corrida de cavalos. }\end{array}$ & $\begin{array}{l}\text { Predomínio de enquadramento } \\
\text { episódico e corrida de cavalos, com } \\
\text { tendência negativa de aparição do } \\
\text { enquadramento temático. }\end{array}$ \\
\hline $\begin{array}{l}\text { Valência da } \\
\text { cobertura }\end{array}$ & $\begin{array}{l}\text { Predomínio de valência positiva } \\
\text { para Dilma; valência negativa e } \\
\text { valência equilibrada com } \\
\text { predomínio para Dilma e Serra; } \\
\text { valência neutra para Marina. }\end{array}$ & $\begin{array}{l}\text { Predomínio de valência positiva e } \\
\text { de valência negativa para Dilma; } \\
\text { valência neutra para Serra e } \\
\text { Marina; valência equilibrada para } \\
\text { Dilma. }\end{array}$ \\
\hline Uso de fontes & $\begin{array}{l}\text { Há maior presença de fontes } \\
\text { externas ao jornal nos textos } \\
\text { informativos. Predomina o tipo de } \\
\text { fonte lobista, com especialistas e } \\
\text { cidadãos individualizados na } \\
\text { mesma proporção. }\end{array}$ & $\begin{array}{l}\text { Há menor presença de fontes } \\
\text { externas ao jornal nos textos } \\
\text { informativos. Maior presença de } \\
\text { lobista, seguido de especialista. } \\
\text { Cidadãos individualizados quase } \\
\text { não aparecem como fontes. }\end{array}$ \\
\hline
\end{tabular}

Parte das diferenças apontadas aqui não pode ser encontrada em uma análise de conteúdo, pois suas explicações encontram-se fora dos próprios veículos. Por exemplo, o fato de a cobertura crescer no portal durante o segundo turno e cair no impresso pode ser consequência de maior participação dos internautas estimulados pelo final da campanha eleitoral. O mesmo pode ser usado para explicar a maior diversificação de fontes no portal do que no impresso. Já o predomínio de enquadramentos episódico e corrida de cavalos no jornal tradicional indica a manutenção da tendência de veículo informativo factual e pouco apto a análises mais aprofundadas, típico do jornalismo diário ocidental da segunda metade do século XX.

\section{Considerações Finais}

Esse estudo insere-se na linha de pesquisa comparada sobre mídia e política. Busca-se comparar o conteúdo disponível nessas duas plataformas com 
o objetivo de identificar similaridades e diferenças no conteúdo produzido e publicado em cada uma delas. Portanto, a partir da análise que abrange o período eleitoral de 2010, observa-se comparativamente o conteúdo produzido no portal Estadão.com e no jornal O estado de São Paulo. Com esses dados foi possível perceber alguns padrões da cobertura, assim como diferenças.

Entre o que é padrão tanto no impresso quanto no portal está a semelhança entre os temas e também a cobertura feita ao longo do tempo. A única diferença evidente quanto aos temas foi a maior presença de campanha no impresso. No caso da produção ao longo do tempo identificou-se produção parecida, com picos em datas semelhantes, sendo que a diferença mesmo ocorreu nos dias que antecederam e sucederam as eleições, sendo que isso se deve ao processo diferente de rotina produtiva da internet e do impresso. Os temas presentes na sociedade são os mesmos abordados por quase todos os veículos, ainda mais os que pertencem aos mesmos grupos. A diferença começa a aparecer, de fato, no tratamento dado às notícias e aos candidatos.

Percebe-se a primeira diferença quanto ao enquadramento. Ele é mais temático no portal e mais episódico no impresso. Esse resultado contraria a hipótese inicial de que a cobertura no portal do Estadão seria mais fragmentada tanto no volume de cobertura, com textos menores e menos citação de candidatos, quanto na temática, com textos mais conjunturais, ou seja, que seriam textos curtos e pouco informativos, sem contextualização já que a cobertura ocorre instantaneamente não havendo tempo de aprofundar e contextualizar os temas abordados. Não foi o que aconteceu. Outra diferença, desta vez confirmando a hipótese inicial da pesquisa, é a tendência dos textos apresentarem mais valências no portal do que no impresso onde há maior percentual de notícias neutras para os candidatos. Embora tenha aumentado também a valência positiva e equilibrada, esses dados vão ao encontro da literatura sobre propaganda negativa na rede.

Outra diferença é na visibilidade dos candidatos que no portal apareceram mais nos títulos dos textos se comparada ao impresso. O aumento em relação ao jornal é de três vezes, aproximadamente, para os três candidatos. Destacase que não muda a sequência, estando sempre Dilma Rousseff à frente. Além disso, o número de fontes também se reduz na cobertura feita pelo jornal em comparação ao portal, seguindo os "achados" de Borges (2007) em que na rede há maior pluralidade de fontes. Para concluir, percebe-se então que há padrões que não mudam na produção jornalística, seja na rede, na televisão, 
no rádio ou no impresso. Mas, por outro lado, há algumas características que se alteram e o que explica essas mudanças são as diferentes rotinas de produção, a cultura jornalística e a força da instituição e das variáveis externas na produção que agem em cada um dos veículos.

Embora ainda que parciais resultados de estudos de caso como esse ajudam a apontar novas questões de pesquisa ou chamar a atenção para revisões de conclusões anteriores. A principal delas, ainda que restrita ao estudo de caso de cobertura eleitoral é que a plataforma tecnológica importa. Ainda que sendo veículos do mesmo grupo empresarial, seguindo mesma linha editorial, submetidos aos mesmos interesses econômicos e produzidos por profissionais com mesmas formações e experiências o portal e o jornal impresso do grupo Estado apresentaram diferenças na cobertura da campanha presidencial de 2010. A principal delas diz respeito aos enquadramentos. Ao contrário das afirmações ensaísticas iniciais sobre o jornalismo na web, quando comparado ao padrão de produção das notícias no meio tradicional, o portal digital mostrou-se mais adequado às discussões aprofundadas, temáticas e com maior pluralidade de fontes. Já o impresso manteve-se no modelo tradicional, com cobertura de factualidades, próxima de um equilíbrio no tratamento dado aos candidatos e mais voltado para os eventos da corrida eleitoral propriamente dita.

\section{Referências Bibliográficas}

Aguiar, L.A. (2007). Os valores-notícia como efeitos de verdade na ordem do discurso jornalístico. Intercom - Sociedade Brasileira de Estudos Interdisciplinares da Comunicação.

Aldé, A. (2004). Jornalistas e internet: a rede como fonte de informação política. IV Encontro dos Núcleos de Pesquisa da Intercom.

Aldé, A. (2005). Critérios jornalísticos de noticiabilidade: discurso ético e rotina produtiva. II Congresso Luso-Brasileiro de Estudos Jornalísticos, Porto.

Alsina, M.R. (2010). A Construção da Notícia. Petrópolis: Vozes.

Althaus, S; Tewksbury, D. (2000). Patterns of Internet and Traditional News Media Use in a Networked Community. Political Comunication, 17. 
Aruguete, N. (2005/2). Los medios de comunicación y la formación de la agenda pública. Verso e Reverso - revista de comunicação, Ano XIX(41), Unisinos.

Azevedo, F.A. (2001). Imprensa e Cobertura Eleitoral: os jornais paulistas e a Eleição municipal de 2000. XXV Encontro Anual da ANPOCS.

Bauer, M. (2002). Análise de conteúdo clássica: uma revisão. In M.W. Bauer, \& G. Gaskell (org.). Pesquisa qualitativa com texto, imagem e som: um manual prático. Petrópolis: Vozes.

Blanco, P.S. (2000). Opinión pública y democracia deliberativa: médios, sondeos y urnas. ISTMO.

Borges, J. (s.d.). Política e jornalismo em tempo real. Webjornalismo e novos espaços de cobertura política. Tese de doutoramento defendida no Instituto Universitário de Pesquisas do Rio de Janeiro (IUPERJ).

Bourdieu, P. (1997). Sobre a televisão. Rio de Janeiro: Zahar.

Braga, S. \& Nicolas, M.A. (2011). O que a internet agrega às eleições? Um balanço inicial do uso da internet pelos candidatos aos governos estaduais e ao senado federal nas eleições brasileiras de outubro de 2010. Trabalho apresentado no IV Congresso da WAPOR, Belo Horizonte.

Correia, J.C. (2004). A fragmentação do Espaço Público: novos desafios éticos políticos. Biblioteca On-line de Ciências da Comunicação. Covilhã: UBI.

Dader, J.L. (2009). Ciberpolítica en los websites de partidos políticos: la experiencia de las elecciones de 2008 en España ante las tendencias transnacionales. Revista de Sociologia e Política, 17(34).

Dader, J.L.; Ayuso, I. (2008). Las webs de partidos españoles 2004-2005: Una investigación preliminar y de comparación europea, con una propuesta metodológica. In M. J. Canel \& M.G. Gurrionero (eds). Estudios de Comunicación Política. Madrid.

Dader, J.L. (1992). El periodista en el espaço publico. Editora: Comunicacion.

Dahl, R. (2009). Sobre a Democracia. Editora UNB.

Dahl, R. (1997). Poliarquia. Editora Edusp. 
New informative platforms and traditional media: synergy or antagonism? 29

Fog, A. (2004). The supposed and the real role of mass media in modern democracy. Working paper.

Galtung, J. \& Ruge, H. (1965). The structure of foreign news. The Presentation of the Congo, Cuba and Cyprus Crises in Four Norwegian Newspapers. Journal of International Peace research: 64-91.

Habermas, J. (1984). Mudança estrutural da esfera pública: investigações quanto a uma categoria da sociedade burguesa. Rio de Janeiro: Tempo Brasileiro.

Habermas, J. (2006). Political Communication in mídia Society: Does Democracy still enjoy na epistemic dimension?The impactof Normative Theory on Empirical Research. Revista Communication Teori, (16): 411426.

Harcup, T. \& O’Neill, D. (2001). What Is News? Galtung and Ruge revisited. Journalism Studies: 261-280.

Kalnes, O. (2009). ¿E-ruptura en la política de partidos? El caso del Web 2.0 y los partidos noruegos. Quaderns del CAC, (33).

Manin, B. (1995). As metamorfoses do governo representativo. Revista Brasileira de Ciências Sociais: Associação Nacional de Pós-Graduação e Pesquisa em Ciências Sociais, outubro, ano 10 (29).

McCombs, M. (2010). A Teoria da agenda: a mídia e a opinião pública. Vozes.

McCombs, M. \& Shaw, D. (1972). The Agenda-Setting Function of Mass Media. Public Opini-on Quarterly, (36): 176-87.

Mielniczuk, L. (s.d.). Características e implicações do jornalismo na Web. Disponível em: www.facom.ufba.br. Acesso em: 28 de dezembro de 2008.

Miguel, L.F. (2000). Um ponto cego nas teorias da Democracia: os meios de comunicação. Revista Brasiléia de Informação bibliográfica em Ciências Sociais, (49).

Montero, M.D. (2009). E-movilización y participación políticas en las campañas electorales de Ségolène Royal (2007) y Barack Obama (2008). Quadernos del CAC, (33). 
Newell, J.L. (2001). Italian political parties on the web. The Harvard International Journal of Press/Politics. (6): 60-87.

Norris, P. (2003). Preaching to the Converted? Pluralism, Participation and Party Websites. Party Politics, 9(1): 21-45.

Ramírez, M. (1992). ¿Qué son las noticias?. Comunicación y Sociedad, (1415): 235-250.

Redondo, F. (2009). Las elecciones gallegas de 2009 a través de los blogs de sus líderes políticos. Quaderns del CAC, (33).

Rocha, H.C.L. (2008). Habermas e a Teoria do Jornalismo: A Manipulação Ideológica no Jornalismo como Distorção Sistemática da Comunicação. Estudos em Comunicação, (4): 41-57.

Serrano, E. (1999). Jornalismo e elites de poder. Biblioteca On-line de Ciências da Comunicação. Covilhã: UBI.

Silva, G. (2005). Para pensar critérios de noticiabilidade. Estudos em Jornalismo e Mídia. II(1), $1^{\circ}$ Semestre.

Shoemaker, P. \& Vos, T. (2009). Gatekeeping Theory. New York: Routledge.

Weaver, D.; McCombs, M. \& Spellman, C. (1975). Water gate and the media: a case study of Agenda-setting. American politics quarterly, 3.

Wolf, M. (2009). Teorias da comunicação. Editora: Presença. 


\title{
A mediação das relações sociais nas redes sociais virtuais: do ciberespaço ao ciberterritório
}

\author{
Rubens Staloch \& Clovis Reis \\ Universidade do Estado de Santa Catarina / Universidade Regional de Blumenau \\ E-mail: rubens.staloch@udesc.br/professorclovisreis@gmail.com
}

\begin{abstract}
Resumo
As tecnologias da informação e da comunicação auspiciam o debate sobre as novas formas de organização social e o desenvolvimento de um novo conceito de território, considerando que este se modifica espaço-temporalmente através da organização humana. A partir de tal premissa, o presente trabalho discute a inserção das redes sociais virtuais (RSVs) na mediação das relações sociais. Postulase que o território é o resultado da im-

quais são mediadas no ciberespaço, por exemplo, através das redes sociais virtuais. O percurso teórico-metodológico culmina com o delineamento inicial do conceito de ciberterritório. A proposta não esgota o diálogo sobre o tema. O objetivo é abrir horizontes para novas discussões, que facilitem o entendimento sobre o alcance das dinâmicas sociais recentes, desenhadas no âmbito do ciberespaço.
\end{abstract} pressão das relações sociais no espaço, as

Palavras-chave: Redes sociais virtuais; ciberespaço; ciberterritório; comunicação.

\section{The mediation of social relationships in virtual social networks: from cyberspace to ciberterritory}

\begin{abstract}
Information and communication technologies sponsor the dialogue on the new forms of social organization and the development of a new concept of territory, considering that this latter changes spatiotemporally through human organization. Based on such premises, the present paper discusses the insertion of vir-

tual social networks (VSNs) on the mediation of social relationships. It is postulated that the territory is the result of the impression of social relations in space, which are mediated, in cyberspace, through virtual social networks. The theoretical and methodological approach ends up with the clarification of the concept
\end{abstract}


of cyber-territory. Our study doesn't discussions, that facilitate the understanexhaust the dialogue about the topic. Its ding about the reach of recent social dygoal is to open up new horizons for new namics occurring in cyberspace.

Keywords: Virtual social lines; cyberspace; cyberterritory; comunication.

\title{
Introdução
}

\begin{abstract}
$\mathrm{A}^{\mathrm{O}}$
analisar a história da humanidade verifica-se que as formas de interação humana eram exclusivamente com pessoas próximas. Desde o final do século XIX, a evolução das tecnologias de informação e comunicação vem se transformando radicalmente e também, os padrões de organização e interação humana. A forma de interação social se transformou de modo que há alterações do controle do espaço.

No final do século XX, as novas tecnologias digitais revolucionaram a comunicação, possibilitando que se compartilhem informações de forma instantânea e simultânea com milhões de pessoas quase em qualquer parte do mundo. Já não é preciso estar próximo fisicamente para manter relações.

Para o presente trabalho, parte-se da premissa de que o território é constituído pelas relações sociais, e então, indaga-se: hoje, sendo as relações sociais dadas no ciberespaço, nas redes sociais virtuais, por exemplo, é possível inferir que há um ciberterritório?

Antes de qualquer ponderação, faz-se uma breve contextualização sobre o conceito de território para que após, se possa formular uma resposta para a pergunta norteadora deste trabalho.

Apesar de ser conceito-chave para a Geografia, o território, também é estudado por demais áreas, cada uma com um enfoque centrado em determinada perspectiva. (Haesbaert, 2007)
\end{abstract}

Enquanto o Geógrafo tende a enfatizar a materialidade do território, em suas múltiplas dimensões (que deve[ria] incluir a interação sociedadenatureza), a Ciência Política enfatiza sua construção a partir de relações de poder (na maioria das vezes, ligada à concepção de Estado); a Economia, que prefere a noção de espaço á de território, percebe-o 
muitas vezes como fator locacional ou como uma das bases da produção (enquanto "força produtiva"); a Antropologia destaca sua dimensão simbólica, principalmente no estudo das sociedades ditas tradicionais (mas também no "neotribalismo" contemporâneo); a Sociologia o enfoca a partir de sua intervenção nas relações sociais, em sentido amplo, e a Psicologia, finalmente, incorpora-o no debate sobre a construção da subjetividade ou da identidade pessoal, ampliando até a escala do indivíduo. (Haesbaert, 2007, p. 37)

É imprescindível entender também que o território está em constante transformação. O entendimento que se tinha deste conceito na Idade Média não é o mesmo do século XX, e esse, por sua vez, não é o mesmo que se tem hoje. O território não se define estritamente pelos seus limites físicos, mas também pela forma como se produz em seu interior, a interação social, demonstrando a relevância dos atores para a construção de relações e dos territórios. Como as relações humanas são dinâmicas, modificam-se espaçotemporalmente, a formação de territórios também tende a sofrer alterações. (Haesbaert, 2007)

Pensar em território requer também entender o espaço. Ambos não são termos equivalentes e nem sinônimos (Raffestin, 2008, p. 26). É fundamental "entender como o espaço está em posição que antecede ao território, porque este é gerado a partir do espaço, constituindo o resultado de uma ação conduzida por um ator que realiza um programa em qualquer nível.” Já, Lefebvre (1992 [1974], p. 26), compreende que as relações sociais não podem ser resumidas ao espaço físico, é o espaço da vida social onde ocorrem as relações entre os seres.

Dessa forma, a base do território é a natureza ou o espaço, onde o homem transforma a partir do seu trabalho, sua intervenção, afirmando que a natureza não produz; ela cria e somente o homem é capaz de produzir através do trabalho. Nestes termos, o modo de produção vigente em cada sociedade é determinante para a produção do espaço. Também, é necessário o entendimento que que não há uma indissociabilidade entre espaço e território. (Lefebvre, 1992 [1974])

Para Raffestin (1993, p. 143), o ator "ao se apropriar de um espaço, concreta ou abstratamente [...] territorializa o espaço", ou seja, o território é modificado pelo trabalho e pelas relações de poder presentes no cotidiano, é um 
espaço onde se projetou um trabalho. Desta forma, as impressões humanas de poder no espaço irão definir o território.

Já para Saquet (2007, p. 77) "o espaço geográfico não é apenas palco, receptor de ações, substrato [...] tem um valor de uso e um valor de troca, distintos significados e é elemento constituinte do território, pois eles são indissociáveis".

Os indivíduos vivem cotidianamente relações sociais, criam relações de poder que se revelam na construção de malhas, nós, redes, que por sua vez, constituem o território, manifestado em diferentes escalas espaço-temporais e sociais, modificando-se no transcorrer do tempo. (Raffestin, 1993)

Estes processos de "composição, decomposição e recomposição dos territórios" se acentuam durante o século XVIII com a Revolução Industrial (Raffestin, 2008, p. 22-23). Essas expressões, ditas de outra forma, constituem uma dinâmica e um movimento constante das conceituações teóricas de território, propiciando o entendimento do que Raffestin (1984, p. 78) apud Saquet (2007, p. 78) e Hasbaert (2006) elencam, a TDR (territorialização, desterritorialização e reterritorialização):

(...) a territorialização implica (...) um conjunto codificado de relações (...), a desterritorialização é, em primeiro lugar, o abandono do território, mas também pode ser interpretada como a supressão dos limites, das fronteiras (...). A reterritorialização (...), pode ocorrer sobre qualquer coisa, através do espaço, a propriedade, o dinheiro etc..

Haesbaert (2007) apresenta pelo menos três enfoques para o conceito de território: a) materialista: onde o território é recurso natural, distância física ou no limite um abrigo; b) idealista: associando território e cultura, uma visão mais simbólica e dos poderes invisíveis; c) e um enfoque integrador entre as diferentes dimensões sociais: naturalista e biológica, relações de poder (Estado-Nação Moderno) e econômica.

Devido a essas diferentes abordagens sobre o território, Haesbaert (2006) enfatiza a existência de uma multiterritorialidade, não-hierárquica e em constante processo de transformação. O território em qualquer compreensão, tem a ver com poder, mas não apenas "poder político" tradicional. Ele diz respeito tanto ao poder no sentido mais concreto, de dominação, quanto ao poder no sentido mais simbólico, de apropriação. 
Hasbaert (2006) ainda diz que há um mito sobre o processo de desterritorialização, ou seja, para ele não há o "fim dos territórios", não há apenas uma desterritorialização, há sempre um processo de territorialização, desterritorialização e re-territorialização - TDR. Uma desterritorialização ocorre devido a interações, sejam elas políticas, culturais, econômicas, e até, naturais, que por sua vez, constituir-se-ão em novas territorialidades, dando início a uma re-territorialização e, assim, caracterizando o movimento da TDR.

Para Saquet (2007) é preciso considerar para o processo de territorialização os quesitos: economia, política, cultura e natureza, considerando ainda, suas relações. O autor aborda a questão de um novo arranjo territorial, com autogestão e autonomia para os sujeitos, sendo que para isso é fundamental compreender e redimensionar as relações de poder que estão no cotidiano de todos.

O território assume distintos significados para diferentes sociedades, o que o caracteriza como dinâmico. As relações de poder são componentes que não podem faltar para a efetivação de um território (Saquet, 2007), que por sua vez “(...) é a cena do poder e o lugar de todas as relações (...)” Raffestin (1993) apud Saquet (2007, p. 34).

Assim, Saquet (2007, p. 127), elenca que "os territórios são produzidos espaço-temporalmente pelo exercício do poder por determinado grupo ou classe social, pelas territorialidades cotidianas." Simultaneamente, as territorialidades são o resultado, condicionantes e dão características da territorialização e do território, porém, não descarta em suas análises a natureza, pois a territorialização é efetivada mediante relações entre a sociedade e a natureza, mediada pelas territorialidades ${ }^{1}$.

As forças sociais efetivam o território, o processo social, no (e com o) espaço geográfico, centrado na territorialidade cotidiana dos indivíduos e emanado dela, em diferentes centralidades, temporalidades e territorialidades, que condicionam nossa vida cotidiana. Formam-se territórios

1. Territorialidade e território não são sinônimos, mas sim, complementares. As territorialidades são definidas, assim como o território, histórico-temporalmente. Em determinados momentos constituem-se a partir de certas relações e em outros momentos se modificam devido as intenções humanas, dando forma a novas configurações, a partir de novas relações sociais, ou seja, resultam de uma construção social formatada espacialmente para um determinado objetivo. Territorialidade então, está diretamente relacionada às interações sociais dos atores, sejam elas, por objetivos políticos, econômicos, etc. 
heterogêneos e sobrepostos fundados em desigualdades e diferenças. Cristalizam-se territorialidades e interesses predominantemente econômicos e/ou políticos e/ou culturais que dão uma certa forma e determinados conteúdos ao território e aos territórios. (Saquet, 2007, p. 128)

De acordo com Sack (2011 [1986]), as territorialidades são constituídas a partir das ações humanas, da tentativa de um indivíduo ou grupo de controlar/influenciar os demais numa área [território] delimitada. Para o autor, as territorialidades são escalares, pois podem ocorrer tanto em níveis do indivíduo, do lar, no trabalho, etc., e, ainda, se alteram de acordo com as relações sociais constituídas.

Quanto ao território, Sack (2011 [1986], p. 78) admite que é um lugar que está sob o controle de uma autoridade, "é uma estratégia para estabelecer diferentes níveis de acesso a pessoas, coisas e relações." Para o autor, o território diz respeito ao "controle de acesso" e esse controle de acesso é dado mediante as territorialidades.

Como se percebe, a construção dos territórios perpassa por diversas questões, de diferentes áreas. Além dos aspectos políticos, Santos (2002 [1996]) também salienta a importância dos aspectos sociais, econômicos e culturais entrelaçados em virtude do movimento da sociedade [territorialidades] no decorrer dos diversos momentos históricos e do desenvolvimento das técnicas na compreensão do território.

Impulsionados pelas tentativas de compreender fenômenos e processos sociais e territoriais, demonstrando a existências de redes de circulação e comunicação, identidades e relações de poder, "no Brasil, tanto a expansão como a qualificação de estudos centrados nos conceitos de território e territorialidade ocorrem, principalmente, a partir do biênio 1992-93", com a participação de autores em seminários internacionais. (Saquet, 2007, p. 120)

Para compreender a constituição dos territórios e das territorialidades, de uma forma resumida, elencou-se as principais características, que por sua vez, são delineadas da seguinte forma: 
A mediação das relações sociais nas redes sociais virtuais: do ciberespaço ao ciberterritório

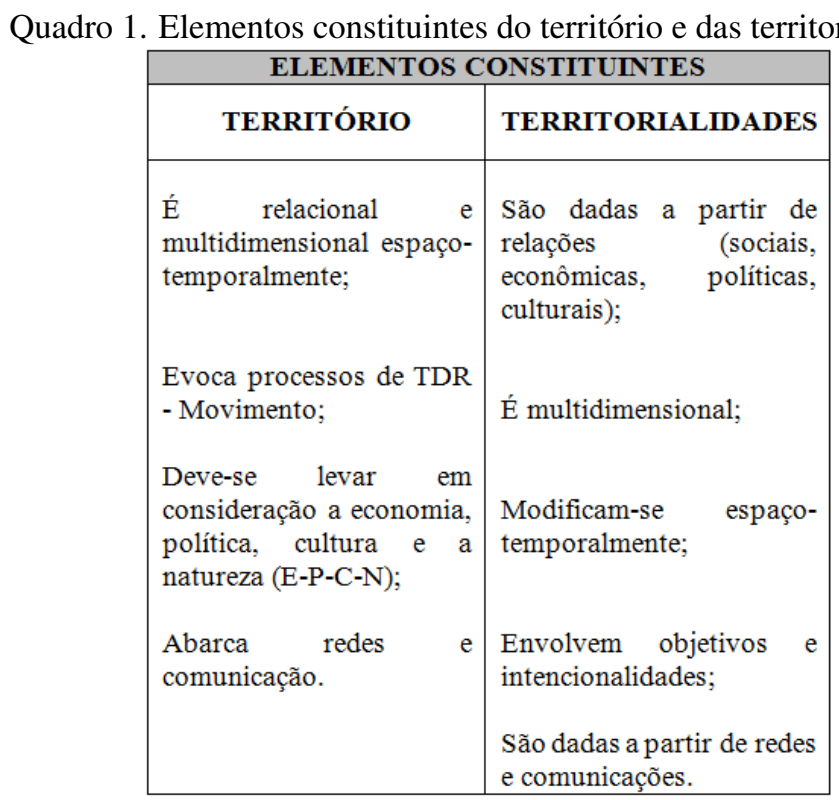

Fonte: Elaborado pelos autores

A desterritorialização está intimamente ligada ao processo de modernidade e globalização, ao período técnico-científico. Saquet (2007) evidencia a formação das redes de circulação e de comunicação como contribuição para o controle do espaço. Elas "agem como elementos mediadores da reprodução do poder da classe hegemônica e ligam o singular ao universal (e vice-versa), interferindo diretamente na territorialidade dos indivíduos e das classes sociais." (Saquet, 2007, p. 129)

Essa desterritorialização possui suas bases no discurso da(s) mobilidade(es), tanto material quanto imaterial, "especialmente aquela diretamente ligada aos fenômenos da compreensão tempo-espaço, propagada pela informatização através do chamado ciberespaço" (Haesbaert, 2006, p. 236).

Desta forma, Haesbaert (2006, p. 270) propõe uma interpretação do território como um híbrido entre a materialidade a imaterialidade, funcionalidade e expressividade, demonstrando que há sempre um processo de territorialização e desterritorialização. 
A diferença está no fato de que nas sociedades disciplinares (mais tradicionais) estão amparadas na dimensão concreta do espaço, enquanto nas sociedades mais modernas estão amparadas em uma dimensão mais abstrata, informacional e organizada em rede decorrente das tecnologias da informação e da comunicação (Castells, 1999). Assim, entende-se que há diferentes perspectivas de territórios, o que Haesbaert (2006) entende por multiterritorialidade:

Multiterritorialidade (ou multiterritorialização se, de forma mais coerente, quisermos enfatizá-la enquanto ação ou processo) implica assim a possibilidade de acessar ou conectar diversos territórios, o que pode se dar tanto através de uma "mobilidade concreta", no sentido de um deslocamento físico, quanto "virtual", no sentido de acionar diferentes territorialidades mesmo sem deslocamento físico, como nas novas experiências espaço-temporais proporcionadas através do ciberespaço.

(Haesbaert, 2006, p. 341-341)

Não se trata apenas de uma transformação meramente quantitativa, mas sim, de "mais alternativas territoriais, maior facilidade de acesso, maior velocidade de mudança" (Haesbaert, 2006, p. 345). Devido a essas novas articulações territoriais, embasadas no ciberespaço, surgem os "territórios-rede flexíveis, onde o mais importante é ter acesso aos pontos de conexão que permitem "jogar" com a multiplicidade de territórios existentes, criando assim uma nova territorialidade" (Haesbaert, 2006, p. 345) e, também, constituindose em constantes desterritorializações e reterritorializações.

De acordo com Haesbaert (2006), um dos principais teóricos sobre a desterritorialização no ciberespaço é Lévy (1999, p. 94), que conceitua ciberespaço como sendo "o espaço de comunicação aberto pela interconexão mundial de computadores e das memórias dos computadores", sendo o virtual a marca desse ciberespaço.

Pode-se dizer que estrutura social de uma sociedade resulta da relação existente entre a tecnologia e a forma de organização social num plano mais geral. A comunicação e a organização em rede transcende fronteiras, é global. Difunde-se através do poder integrado nas redes globais (Castells, 1999). Desse modo, "territorializar-se significa também, hoje, construir e/ou controlar fluxos/redes e criar referenciais simbólicos num espaço em movimento, no e pelo movimento" (Haesbaert, 2006, p. 280). 
De forma geral, os territórios são relacionais e multidimensionais espaçotemporalmente; Evocam movimento, - processos de TDR; Deve-se levar em consideração a economia, política, cultura e a natureza em sua formatação e abarca redes e comunicação.

Assim sendo, o território como um produto social, relacional e histórico pode também ser condicionado e idealizado de forma virtual, no ciberespaço? Ou melhor, é possível inferir que hoje, com as tecnologias da informação e comunicação e da internet, e das relações sociais nas redes sociais virtuais, existe um ciberterritório?

Tentando responder esta pergunta, o presente trabalho pautou-se em fazer, na próxima seção, uma abordagem sobre o conceito de ciberespaço e a formatação das redes sociais virtuais neste.

Após, discute-se o conceito de ciberespaço e as relações sociais construídas pelas redes sociais virtuais (RSVs), para que seja possível correlacionar a formação de territórios a partir de relações mediadas pelo computador, mais precisamente, através da RSVs no ciberespaço, dando um delineamento no conceito de ciberterritório.

\section{Ciberespaço e redes sociais virtuais}

Estudos demonstram que a internet pode contribuir para a interação social online e off-line de forma muito significativa. Por mais que existam céticos com relação a utilização da internet para a mediação das relações, pesquisas mostram que os usuários conectados conversam muito mais por outros meios, inclusive, por telefone, do que pessoas que não estão conectadas a rede. Sendo assim, a questão colocada de que a internet [diga-se também, as relações no ciberespaço] acaba colocando os atores em isolamento social se desfaz. (Katz et al., 2001)

O ciberespaço é "o espaço de comunicação aberto pela interconexão mundial de computadores e das memórias dos computadores", sendo o virtual a marca desse. (Lévy, 1999, 94)

O termo especifica não apenas a infraestrutura material da comunicação digital, mas também o universo oceânico de informações que ela abriga, assim como os seres humanos que navegam e alimentam esse universo. Quanto ao neologismo (materiais e intelectuais), de práticas, 
de atitudes, de modos de pensamento e de valores que se desenvolvem juntamente com o crescimento do ciberespaço. (Lévy, 1999, p. 17)

Esse ciberespaço está pautado na virtualização, que não é uma desrealização, o que aumenta os graus de liberdade. Lévy (1999) diz que a virtualização pode ser encarada como um sinônimo de desterritorialização quando "o ciberespaço encoraja um estilo de relacionamento quase independente dos lugares geográficos [...] e da coincidência dos tempos.” (Lévy, 1999, p. 51)

Surgem novas territorializações embasadas na organização em rede, descritas por Castells (1999), que tem como características a mobilidade ou o movimento. As territorialidades, assim como as tecnologias são multidimensionais. As tecnologias, principalmente a estruturação de comunicações via internet, começam a tomar forma nos anos de 1960, emergindo um novo paradigma tecnológico, o da comunicação online. Para Castells (1999), a tecnologia não define a sociedade, ela é a sociedade, inclusive, possibilitando relações de poder.

É importante ressaltar que o conceito de redes não é uma exclusividade do universo tecnológico. Não se constituem apenas devido às tecnologias da informação e comunicação (TICs). São formas muito antigas de práticas humanas. Os seres humanos estão inseridos em uma sociedade através de relações que constroem ao longo de suas vidas, primeiro no âmbito familiar, escolar, no trabalho, etc., e, assim, a própria natureza humana nos conduz a uma estrutura de organização em rede.

Watts (2009, p. 11) conceitua rede como sendo "um conjunto de objetos conectados entre si de certo modo". Quando se fala em rede, podemos falar tanto de uma grande empresa, de roteadores na internet ou até de neurônios, porém, todas estas possuem formas distintas umas das outras.

Todos os organismos vivos são uma rede, desde o corpo até a relação com os demais seres e com a própria natureza. O padrão de rede é um dos padrões de organização mais básico de todos os sistemas vivos. (Capra, 1996, 2001)

Em todos os níveis da vida existem redes de conexões, de interligação, desde o sistema metabólico do corpo até as teias alimentares dos ecossistemas. Dessa forma, Capra (1996) chama a atenção para o fato de que os componentes e os sistemas vivos se interligam sob a forma de rede.

Embora a metáfora descrita por Capra (1996) possa ajudar na compreensão da estrutura em rede, não podemos transportá-la para o domínio social 
sem antes considerar as características que a definem. Para entender o sistema metabólico do corpo humano é preciso, antes de tudo, entender que este é um padrão não-linear de organização. É preciso entender de biologia molecular e de bioquímica para compreender a natureza das conexões e suas funções dentro do sistema.

Assim, também se deve fazer para analisar uma rede social que, por sua vez, é um sistema não-linear de organização. Os nós e as conexões dessas redes, diferentemente da rede molecular, não são dadas a partir de elementos bioquímicos, mas sim, de elementos sociais, envolvendo a história, a cultura, a linguagem, a comunicação, fenômenos, etc..

As redes sociais são dadas por conexões, diretas e indiretas, que ligam uma pessoa ou grupo a outras pessoas ou grupos. Estas podem ser constituídas de forma direta quando incluem pessoas que você conhece (amigos) e, indireta quando são formadas por relações de "segundo grau" (amigos de amigos).

No momento em que se vive, a organização social está pautada em torno de novos padrões em rede, pois, são constituídas através de meios de comunicação. Como redes sempre remetem a agrupamentos, a coletivos com uma dinâmica desenvolvida para que ocorra sempre a interação entre os atores, as tecnologias digitais ocupam um papel central nas profundas mudanças experimentadas em todos os aspectos da vida social, constituindo novos paradigmas. (Recuero, 2011)

As relações sociais contemporâneas estão se modificando devido à utilização destas tecnologias, principalmente da internet na composição de redes de comunicação e interação, as chamadas redes sociais. (Recuero, 2011)

De acordo com Castells (1999), as tecnologias da informação e comunicação são sensíveis aos usos sociais. A tecnologia é condição necessária, mas, não somente para a emergência de uma organização social baseada em redes, nós, conexões. É necessária a adaptação e a vivência dos agentes (indivíduos) nessa nova forma de organização.

Para que se chegasse nos atuais modos de interação via internet foi necessário uma série de novos conhecimentos e inovações tecnológicas que demorou mais de 30 anos para se desenvolver. Ao final de 1995, que foi o primeiro ano em que a internet foi amplamente utilizada e disseminada, havia 16 milhões de usuários (Castells, 2003). Já, em 2014, de acordo com o site Internet 
World Stats $^{2}$ havia em dezembro de 2013 quase 3 bilhões de usuários, o que representa um nível de penetração da internet na ordem de 39\%.

A chegada da internet, então, significa que os dados podem ser processados de forma muito rápida em quase qualquer parte do mundo, não existindo a proximidade física entre os indivíduos envolvidos ou conectados, surgindo assim o ciberespaço.

Presume-se que a partir do desenvolvimento dos meios de comunicação e informação, da internet, as relações sociais passaram a ser organizadas não mais delimitadas a um espaço físico ou geográfico, mas sim, essas relações passaram a ocorrem independentes de tempo e espaço. Passaram a ocorrem em um ciberespaço, em grande parte, após os anos 2000, nas redes sociais virtuais. (Recuero, 2011)

Recuero (2011) propõe-se a pensar nessas redes e reconhece-as como agrupamentos complexos instituídos por interações sociais, apoiadas em tecnologias digitais, para pensar os aspectos individuais, coletivos e tecnológicos dos agrupamentos humanos na rede de internet, em um denominado ciberespaço. $\mathrm{Na}$ internet os dados podem ser processados de forma muito rápida em quase qualquer parte do mundo, não existindo a necessidade de proximidade física entre os indivíduos envolvidos ou conectados, eis o ciberespaço.

O ciberespaço representa o resultado de um movimento internacional de jovens com vontade de experimentar coletivamente formas de comunicação diferente daquelas que a mídia clássica propõe. Dessa forma, é "o novo meio de comunicação que surge da interconexão mundial de computadores." (Levy, 1999, p. 17)

Lévy (1999, p. 94) define-o como "o espaço de comunicação aberto pela interconexão mundial de computadores e das memórias dos computadores", permitindo vários modos de comunicação. Três são os princípios básicos que orientam o crescimento inicial do ciberespaço: "a interconexão, a criação de comunidades virtuais e a inteligência coletiva." (Lévy, 1999, p. 129)

Essa interconexão mundial de computadores, designada ciberespaço, remodela a sociedade, pois causa um impacto social e cultural muito forte, tanto positivamente, quanto negativamente, principalmente na discussão sobre o poder, como aborda Lévy (1999). A revolução da tecnologia está remodelando

2. Internet World Stats. Disponível em:www.internetworldstats.com. Acesso em: 01 de outubro de 2014. 
a base material da sociedade, apresentando uma nova forma de relação entre a economia, o Estado e a sociedade, onde "as redes interativas de computadores estão crescendo exponencialmente criando novas formas e canais de comunicação, moldando a vida e, ao mesmo tempo, sendo moldadas por ela." (Castells, 1999, p. 22)

Inclusive, pode-se dizer que há uma relação híbrida entre as relações nos lugares físicos e no ciberespaço. Nesse sentido há uma interpenetração, entre o on-line e o off-line, conforme descreve Malini (2013). O ciberespaço fez com que a rua e a rede se interpenetrassem, surgindo uma política colaborativa e em tempo real. Para o autor, o ciberespaço é um ambiente virtual comunitário e participativo de grupos de discussão.

Em seu livro "A Internet e a rua", Malini (2013) destaca, com base nos protestos ocorridos no Brasil e no mundo, a hipótese de que a rua e a rede se interpenetram, fazendo surgir uma relação direta e em tempo real, há uma interpenetração. No caso de movimentos sociais, tal interpenetração ocorre de uma forma tão simbiótica que a rua e a rede parecem uma só.

Desta forma, a internet foi apropriada por se tornar um espaço constante de tensão de diferentes movimentos e poderes, culminando em uma mobilização global político-afetiva, nas ruas e nas redes (Malini, 2013), como pode ser observado nos movimentos da Primavera Árabe, Occupy Wall Strett, 15M na Espanha e nas mobilizações no Brasil em junho de 2013, todas desencadeadas de forma on-line, mais precisamente, através de redes sociais virtuais e também interpenetradas com as ruas.

Se pode dizer que a internet não é o futuro, mas sim, o presente. Essa tecnologia é muito mais do que uma tecnologia, é um meio de comunicação, de interação e organização social, assim, pode-se dizer que a emergência da internet como meio de comunicação fez com que ocorresse uma nova interpretação, como culminação de um processo histórico de desvinculação entre localidade e sociabilidade na formação da comunidade: "novos padrões, seletivos, de relações substituem as formas de interação humanas territorialmente limitadas." (Castells, 2003, p. 98)

A internet "é uma extensão da vida como ela é, em todas as suas dimensões e sob todas as suas modalidades" (Castells, 2003, p. 100). Nesse sentido, as redes que se formam no ciberespaço são constituídas através da comunicação, pela linguagem simbólica, por relações construídas espaço- 
temporalmente. Assim, "estudar redes sociais, [...] é estudar os padrões de conexões expressos no ciberespaço." (Recuero, 2011, p. 21)

Falar em rede social implica falar em elementos essenciais à construção delas, sendo eles os atores e as conexões. Os atores são o primeiro elemento de uma rede social. São as pessoas envolvidas na rede que se analisa. "Como partes do sistema, os atores atuam de forma a moldar as estruturas sociais, através da interação e da constituição de laços sociais." (Recuero, 2011, p. 25)

Devido ao distanciamento físico entre os atores sociais, eles não são imediatamente discerníveis, mas há sempre um processo de construção de identidade e expressão por parte dos atores no ciberespaço. Os sites de redes sociais, que são Softwares Sociais, com aplicação direta para a comunicação mediada por computador", como o Myspace, Twitter e Facebook são formas de apropriação de espaços por parte dos atores. "Funcionam como uma presença do "eu" no ciberespaço, um espaço privado e, ao mesmo tempo público". (Recuero, 2011, p. 27)

Mas como é possível compreender a interação social no ciberespaço? São vários os elementos que precisam ser considerados para isso. Recuero (2011, p. 31) coloca que "o ciberespaço e as ferramentas de comunicação possuem particularidades a respeito dos processos de interação", por isso, a importância dos estudos das redes sociais virtuais (RSV).

A interação é construída pela mediação do computador, possuindo com característica de migração, ou seja, "as interações entre os atores sociais podem [...] espalhar-se entre as diversas plataformas de comunicação" (Recuero, 2011, p. 36). A interação é geradora de laços sociais, fortes ou fracos.

São laços fortes, quando "se caracterizam pela intimidade, pela proximidade e pela intencionalidade em criar e manter uma conexão entre duas pessoas". Já, os laços fracos são dados "por relações esparsas, que não traduzem proximidade e intimidade" (Recuero, 2011, p. 41). Desta forma, a relação/interação é considerada a unidade básica de uma rede social. Porém, "uma relação sempre envolve uma quantidade grande de interações". (Recuero, 2011, p. 37)

O desenvolvimento tecnológico proporcionou uma certa flexibilidade na manutenção e criação de laços sociais, uma vez que permitiu que eles fossem dispersos espacialmente. Isso quer dizer que a comunica- 
ção mediada por computador apresentou às pessoas formas de manter laços sociais fortes mesmo separadas a grandes distâncias, graças a ferramentas como o Skype [...] Essa desterritorialização dos laços é consequência direta da criação de novos espaços de interação. (Recuero, 2011, p. 44)

As redes sociais virtuais (RSV) são denominadas assim, pois as relações, interações e conexões entre os atores são desencadeadas através da comunicação mediada pelo computador, num plano virtual, no ciberespaço. Os principais atributos das RSV são: a sua dinamicidade; capacidade de constituir comunicação horizontalizada; os indivíduos podem se organizar de forma autônoma; possibilitam múltiplas conexões e são potencializadoras, pois, assumem papel potencializador em ações desempenhadas pelos indivíduos.

Importante ressaltar que as relações não precisam ser formadas apenas de interações que construam ou acrescentam algo, podem também ser formadas a partir de interações conflituosas. "A ideia de relação social é independente do seu conteúdo" (Recuero, 2011, p. 37).

No ciberespaço, através das RSVs as relações humanas estão se modificando, demonstrando que o mundo está em constante processo de transformação estrutural e social. Como o território não se define estritamente pelos seus limites físicos, mas, também, pela forma como se produz, em seu interior, a interação social, assim, demonstrando a relevância dos atores para a construção das territorialidades e dos territórios.

Se as relações sociais são dadas pela interação humana em determinado período de tempo e sob objetivos e intencionalidades, hoje, constata-se que as relações estão mediadas no ciberespaço. Como o território é constituído pelas interações humanas, pelas relações de poder, econômicas, sociais, etc., é possível dizer que a partir das relações mediadas pelas RSVs há a constituição de um ciberterritório? Para delinear uma possível afirmação, a próxima seção se propõe a correlacionar o que os assuntos descritos até então.

\section{Ciberespaço, redes sociais virtuais e a constituição de ciberterritório}

Hoje, há a constituição de relações sociais entre os indivíduos, mesmo estando em territórios físicos distantes, de forma horizontalizada, autônoma e automediada. Pode-se dizer que há uma nova territorialidade, num ciberespaço, estreitando os laços entre os indivíduos. "Os vínculos cibernéticos 
colaboram para que as pessoas, que antes teriam vidas sociais mais limitadas, tenham contatos mais diversificados pelas redes" (Labadessa, 2012, p. 84), tornando as territorialidades, não mais limitadas fisicamente e, sim, expandidas ao ciberespaço que, por sua vez, é um agente de libertação.

É tudo construído pela mediação do computador. Essa interação social no ciberespaço pode se dar de forma síncrona ou assíncrona. Síncrona quando simula uma interação em tempo real, como nos canais de chat ou, mesmo, nos bate-papos das redes sociais virtuais. São interações em que ambos os atores estão presente, no mesmo momento em uma mesma conexão. (Recuero, 2011)

Já, as interações assíncronas, são aquelas que permanecem mesmo quando os atores estão desconectados do ciberespaço, por exemplo, o e-mail e os fóruns, onde a expectativa de resposta não é imediata. (Recuero, 2011)

Uma RSV é disseminada nos sites de redes sociais. Recuero (2011, p. 102) define-os como "os espaços utilizados para a expressão das redes sociais na internet", ou seja, permitem a visibilidade, a articulação das redes sociais e a própria manutenção dos laços sociais existentes no espaço off-line. Os sites de redes sociais permitem a expressão da rede social.

Uma rede social é sempre um conjunto de atores e suas relações, ou seja, suas conexões. A RSV - no ciberespaço - no âmbito dos indivíduos possibilita novas combinações de emprego e trabalho autônomo, expressão individual, cooperação e sociabilidade e, para os ativistas políticos, ela tornará possível que redes de indivíduos se combinem e cooperem para disseminar sua mensagem no mundo, conforme elenca Castells (2013).

Nesse ciberespaço, as redes sociais virtuais encorajam os indivíduos a se relacionarem uns com os outros, independentemente da localização geográfica em que estão. Assim é a estrutura organizacional que define essa era (Castells, 1999): a organização em rede, dadas através das tecnologias da informação e comunicação, revolucionando a maneira como os indivíduos interagem, como se mobilizam e como podem constituir territorialidades.

É preciso, ainda, entender que nenhuma rede social é estática; está em constante movimento, portanto, é dinâmica. Assim, uma RSV também possui tais características, suas estruturas, as conexões e formas de relacionamentos podem ser alteradas ao longo dos tempos e dos modos de vida de cada ator, diz-se que as estruturas se modificam devido à dinâmica existente nestas RSVs. 
Através destas redes, os indivíduos podem inclusive se organizarem em comunidades virtuais, que nada mais é, do que um grupo de pessoas que estabelecem entre si relações sociais, que permanecem um tempo suficiente para que elas possam constituir um corpo organizado, através da comunicação mediada por computador (Recuero, 2011), que estão carregadas de interesses, por isso, os indivíduos, são cooperativos, independentemente da localização geográfica em que estão. (Lévy, 1999)

As comunidades virtuais podem ser elencadas como uma forma de organização na cibercultura, descrita por Lévy (1999), gerando uma forma de cooperação básica e necessária para a formação de RSV. Porém, o conflito é igualmente frequente nas RSV, principalmente quando existem atores dentro de determinada rede que, por exemplo, em uma determinada postagem de um ator A, um ator B comenta de forma ofensiva e agressiva, contrariando-se sobre a postagem. O conflito imediatamente surge.

Os conflitos, em uma RSV não são totalmente negativos. Em muitos casos são positivos, pois são estes que possibilitam as discussões e as interações entre os atores, tornando a rede mais dinâmica. "Esses processos dinâmicos são, portanto, essenciais para a percepção das redes sociais no tempo e sua compreensão, enquanto elementos não estáticos". (Recuero, 2011, p. 86)

Quando ocorre a criação de um grupo, por exemplo, no Facebook, há a interação social entre os atores, porém, há muito mais do que isso. Existe neste grupo uma RSV que expressa a identidade dos atores, constituindo-se assim, uma forma de mostrar quem se é no sistema. Cada ator que se engaja na rede se une a ela de forma a cooperar, porém, surgem naturalmente as competições e os conflitos.

Não se pode esquecer de que "os sistemas sociais e as redes sociais, [...] estão em constante mudança" (Recuero, 2011, p. 88), pois, como já elencado no decorrer do trabalho, as redes são sempre redes vivas, incluindo RSV.

Logo, se os territórios são constituídos pelas relações sociais, diga-se, pelas territorialidades, formatadas em diferentes tempos, por que não dizer que hoje, com a ascensão das relações a partir das RSVs, há a constituição de ciberterritórios?

Para tentar demonstrar que isso é possível, faz-se uma correlação entre os quesitos que delineiam os territórios e como tais podem ser delineados no ciberespaço através das RSVs. 
Quadro 2. Correlação dos elementos constituintes do território e a sua delineação no

\begin{tabular}{|c|c|}
\hline TERRITÓRIO & DELINEAÇÃO NO CIBERESPAÇO \\
\hline $\begin{array}{l}\text { É relacional } \\
\text { multidimensional espaço- } \\
\text { temporalmente; }\end{array}$ & $\begin{array}{l}\text { No ciberespaço, através das RSVs, os processos de } \\
\text { constituição dos territórios também são relacionais e } \\
\text { multidimensionais espaço-temporalmente. O ciberespaço não } \\
\text { é apenas um fenômeno das tecnologias, é uma revolução no } \\
\text { modo de pensar o espaço e viver nele. A cada dia é possível } \\
\text { se conectar com novos indivíduos distantes fisicamente, ou } \\
\text { seja, é possível "[...] a transposição de fronteiras territoriais, } \\
\text { articulando as ações locais às regionais, nacionais e } \\
\text { transnacionais; temporais [...]". (WARREN, 2006, p. 126- } \\
\text { 127) }\end{array}$ \\
\hline $\begin{array}{l}\text { Evoca processos de } \\
\text { movimento - TDR; }\end{array}$ & $\begin{array}{l}\text { Se os territórios evocam processos de movimento, nas RSVs } \\
\text { no ciberespaço, estes movimentos são muito mais dinâmicos } \\
\text { e rápidos, pois fluem através das redes de internet. }\end{array}$ \\
\hline $\begin{array}{lr}\text { Devem-se } & \text { levar } \\
\text { consideração } & \text { relações } \\
\text { econômicas, } & \text { políticas, } \\
\text { culturais e naturais; }\end{array}$ & $\begin{array}{l}\text { No ciberespaço, as relações econômicas, políticas, culturais e } \\
\text { naturais podem ser formatadas mediante a conexão dos } \\
\text { computadores, ou seja, "a extensão do ciberespaço } \\
\text { acompanha e acelera uma virtualização geral da economia e } \\
\text { da sociedade" (LÉVY, } 1999, \text { p. 51) }\end{array}$ \\
\hline Abarca redes e comunicação. & $\begin{array}{l}\text { Para a constituição dos territórios é necessária a constituição } \\
\text { de redes, basicamente de comunicação. Através das RSVs no } \\
\text { ciberespaço, tais redes, são, antes de tudo, um instrumento de } \\
\text { comunicação, e assim, podem dar origem a um universal por } \\
\text { contato. Pode conectar os espaços (LÉVY, 1999) e os } \\
\text { indivíduos. }\end{array}$ \\
\hline
\end{tabular}

Fonte: Elaborado pelos autores

Dessa forma, delineando um conceito, o ciberterritório poderia ser entendido como o espaço, não-físico, de interação social, assim como no território físico, porém, mediado pelas redes e conexões no ciberespaço, onde se inserem os diálogos, as mobilizações ${ }^{3}$, as ações e os conflitos inerentes de uma sociedade, não descartando que transformações sociais possam ocorrer em decorrência destas interações.

3. Diversos são os movimentos sociais que emergiram das redes sociais virtuais no ciberespaço, dentre os que podemos destacar: Primavera Árabe; Occupy Wall Street; Movimento 15M na Espanha e as Mobilizações ocorridas no Brasil em junho de 2013. (Castells, 2013) e (Malini, 2013) 
Assim, "há núcleos de redes da internet, em âmbito local e global, e há redes pessoais, vibrando ao ritmo de um novo tipo de revolução, cujo ato mais revolucionário é sua própria invenção". (Castells, 2013, p. 116). Verificase então, que a forma como os indivíduos se organizam, hoje, já é um novo produto, uma nova forma de interação dos atores sociais através de uma autocomunicação em massa dadas nas redes sociais virtuais no ciberespaço, que por sua vez, podem resultar na constituição de um ciberterritório.

\section{Considerações}

A comunicação possibilita que se compartilhem informações instantânea e simultaneamente entre os indivíduos. Após o século XIX, mais precisamente, no século XXI, a tecnologia tem possibilitado modificações radicais nos processos de comunicação, e, por consequência, nos processos de interação social também.

Hoje, conforme Castells (1999), "a rede é a mensagem". Mas, o que isso quer dizer, de fato? Como a vida cotidiana dos indivíduos é mediada pelas comunicações, seja gestual, escrita ou fonética, assim, o que Castells (1999) elenca é que as relações sociais se modificaram com a chegada das tecnologias da informação e comunicação, mais precisamente, os avanços da internet. Esse feito possibilitou que uma nova infraestrutura comunicacional emergisse, organizada em rede, no ciberespaço.

Também, nesse ciberespaço, estão as RSVs - redes sociais virtuais -, que possibilitam a organização e difusão de mensagens via internet, dando o caráter organizacional em rede que Castells (1999) destaca. Através destas redes, os indivíduos podem, inclusive, se organizarem em comunidades virtuais com propósitos específicos, como por exemplo, para a realização de mobilizações sociais.

Mas, de que forma toda esta organização se relaciona com a formação dos territórios, ou melhor, de um ciberterritório?

Se, os territórios são o resultado da impressão das relações sociais no espaço, e, no ciberespaço, estas relações são virtuais, dadas, por exemplo, através das RSVs, há uma desterritorialização, dos espaços físicos, para uma re-territorialização, no espaço virtual, onde os indivíduos constituem relações sociais, dinâmicas, automediadas e livres de qualquer poder, que por sua vez, é uma das principais características da internet. 
Sendo assim, se existe uma relação social mediada no ciberespaço, unindo todos os conceitos e temas abordados no trabalho aqui exposto, reitera-se, após o percurso teórico-metodológico, que é possível o delineamento de um ciberterritório: o espaço, não-físico, de interação social, assim como no território físico, porém, mediado pelas redes e conexões no ciberespaço, onde se inserem os diálogos, as mobilizações, as ações e os conflitos inerentes de uma sociedade, não descartando que transformações sociais possam ocorrer em decorrência destas interações.

Não se teve como objetivo esgotar os diálogos sobre o assunto, muito pelo contrário, o intuito é abrir horizontes para novas discussões, que possam contribuir para o entendimento das dinâmicas sociais recentes, desenhadas no âmbito do ciberespaço.

\section{Referências}

Capra, F. (1996). A teia da vida: uma nova compreensão científica dos sistemas vivos. São Paulo: Cultrix/Amana-Key.

Capra, F. (2001). Conexões ocultas. São Paulo: Cultrix/Amana-Key.

Castells, M. (2003). A galáxia da internet: reflexões sobre internet, negócios e sociedade. Lisboa: Fundação Calouste Gulbenkian.

Castells, M. (1999). A sociedade em rede. São Paulo: Paz e Terra.

Castells, M. (2013). Redes de indignação e esperança: movimentos sociais na era da internet. Rio de Janeiro: Zahar.

Haesbaert, R. (2006). O mito da desterritorialização: do "fim dos territórios" à multiterritorialidade. Rio de Janeiro: Bertrand Brasil.

Haesbaert, R. (2007). Definindo território para entender desterritorialização. In M. SANTOS, Território, territórios: ensaios sobre o ordenamento territorial. Rio de Janeiro: Lamparina.

Internet World Stats. Disponível em: www.internetworldstats.com. Acesso em: 01 de outubro de 2014.

Katz, J.; Rice, R.E. \& Aspden, P. (2001). The internet, 1995-2000: Access, Civic Involvement, and Social Interaction. American Behavioral Scientist, 45 . 
A mediação das relações sociais nas redes sociais virtuais: do ciberespaço ao ciberterritório

Labadessa, E. (2012). O uso das redes sociais na internet na sociedade brasileira. Revista Metropolitana de Sustentabilidade - RMS, São Paulo, maio/ago, 2(2): 82-94.

Lefebvre, H. (1992) [1974]. The production of the space. Oxford: Blackwell.

Levy, P. (1999). Cibercultura. São Paulo: Ed. 34.

Malini, F. (2013). A internet e a rua: ciberativismo e mobilizações nas redes sociais. Porto Alegre: Sulina.

Raffestin, C. (1993). Por uma geografia do poder. São Paulo: Ática.

Raffestin, C. (2008). A produção das estruturas territoriais e sua representação. In M.A. Saquet, Territórios e territorialidades: teorias, processos e conflitos. Expressão Popular: UNESP. Programa de Pós Graduação em Geografia.

Recuero, R. (2012). A rede é a mensagem: efeitos da difusão de informações nos sites de rede social. In E. Vizer (Org.). Lo que Mcluhan no previó, vol. 1 (pp. 205-223), $1^{a}$ ed. Buenos Aires: Editorial La Crujía.

Recuero, R. (2001). Comunidades virtuais: uma abordagem teórica. Seminário internacional de comunicação, 5., Santa Catarina, RS. Anais... Santa Catarina, RS. Disponível em: http://pontomidia.com.br. Acesso em: 27 de novembro de 2013.

Recuero, R. (2011). Redes sociais na internet. Porto Alegre: Sulina.

Sack, R.D. (1986). O significado de territorialidade. In L.C. Dias \& M. Ferrari, Territorialidades humanas e redes sociais. Florianópolis : Insular.

Santos, M. (2002) [1996]. A natureza do espaço. São Paulo: Edusp.

Santos, M. (2007). Território, territórios: ensaios sobre o ordenamento territorial. Rio de Janeiro: Lamparina.

Saquet, M.A. (2007). Abordagens e concepções de território. São Paulo: Expressão Popular.

Saquet, M.A. (2004). O território: diferentes interpretações na literatura italiana. In A.D. Ribas, E.S. Sposito \& M.A. Saquet, Território e Desenvolvimento: diferentes abordagens. Francisco Beltrão: Unioeste.

Saquet, M.A. (2008). Territórios e territorialidades: teorias, processos e conflitos. Expressão Popular: UNESP. Programa de Pós-Graduação em Geografia. 
Saquet, M.A. (2011). Por uma abordagem territorial. In M.A. Saquet, Por uma geografia das territorialidades e das temporalidades. São Paulo: Expressão Popular .

Warren, I.S. (2006). Das mobilizações às redes de movimentos sociais. Sociedade e Estado, Brasília, jan./abr, 21(1): 109-130.

Watts, D.J. (2009). Seis graus de separação: a evolução da ciência de redes em uma era conectada. São Paulo: Leopardo. 


\title{
As lutas dos indignados espanhóis em 25 de setembro de 2012 em Madrid
}

\author{
Diego de Carvalho \\ UNISINOS \\ E-mail: diegodcarv@uol.com.br
}

\begin{abstract}
Resumo
Neste artigo buscamos analisar um dos acontecimentos mais importantes das lutas espanholas, o 25 de setembro de 2012. Buscamos mostrar que os coletivos envolvidos produziram um acontecimento auto-organizado, sendo o caos criado pela repressão policial. Mais importante no artigo é a possibilidade de am-

pliar os componentes de luta na Espanha, neste caso a população espanhola, que de forma corrente é considerada passiva por não sair as ruas nas manifestações. A aproximação mais importante do empírico se refere a produções minoritárias na web como também a produções dos meios de massa.
\end{abstract}

Palavras-chave: Multidão; indignados espanhóis; Web 2.0; Foucault.

\section{The struggles of the Spanish indignados on September 25, 2012 in Madrid}

\begin{abstract}
In this article we analyze one of the most important events of the Spanish struggle, the September 25, 2012. We seek to show that collectives involved produced a selforganized manifestation, being the chaos created by police repression. More important in this article is the possibility of

expanding the components of fighting in Spain, in this case the Spanish population that is considered passive in part by not going to the streets in demonstrations. The empirical approach refers to web minority productions as well as productions of mass media.
\end{abstract}

Keywords: Crowd; spanish struggles; Web 2.0; Foucault. 


\section{Introdução}

TO início de 2011 vimos revoltas no norte do continente africano, tendo como ponto inicial a Tunísia. As lutas, em pouco tempo, se espalharam pela Argélia, Síria, Líbia, pelo Líbano, Egito, Iraque entre outros países. As revoltas, denominadas de Primavera Árabe e de Revolução Democrática Árabe, foram consideradas "la primera gran oleada de protestas laicas y democráticas del mundo árabe en el siglo XXI.” (http://es.wikipedia.org). As redes sociais foram determinantes na organização e difusão das lutas, tanto internamente, quanto na divulgação para o resto do globo - claro que também a mídia de massa teve seu papel na disseminação de informação sobre o que acontecia no mundo árabe.

Em maio de 2011, influenciados por essas revoltas e pela crise que afeta muitos países europeus jovens tomam a principal praça de Madrid, na Espanha. De início, programaram manifestações, no entanto, após assembleia decidiram acampar. A partir daí criaram um ciclo de lutas que tomou as principais praças de mais de 80 localidades na Espanha. Os sujeitos atores dessas manifestações foram chamados de "indignados" e reunidos sob a denominação de Movimento 15 de Maio - 15M. No artigo, também chamamos os sujeitos envolvidos nas lutas de "indignados", mas não fazemos referências mais diretas ao $15 \mathrm{M}$, já que este nos anos seguintes a 2011 é apenas mais um dos nós nas lutas espanholas. Aliás, nó que é o mais importante em nossa pesquisa de doutorado.

As lutas se espalharam por toda Europa após a revolta espanhola principalmente, entre os países mais afetados pela crise, como Portugal e Grécia. Em outubro de 2011 acontece a difusão global de lutas ocorrendo manifestações em todos os continentes, e também no Brasil. No país são formadas ocupações de praças em São Paulo, Rio de Janeiro, Salvador e Porto Alegre entre outras cidades. Isso dura até o início de 2012. Em 2013, acontecem revoltas em massa na Turquia, novamente no Egito, obviamente, na Europa e também em todo o Brasil; ou seja, o devir revolucionário que começou no mundo árabe e se espalhou no ocidente a partir da Espanha, continuou movimentando boa parte do globo.

Neste artigo centramos nossa análise em um dos acontecimentos mais importantes das lutas espanholas, as demonstrações em Madrid que começaram em 25 de setembro de 2012, o 25S. Decidimos investigar esse acontecimento, 
pois em nossa pesquisa de doutorado um dos objetivos é fazer um mapeamento das inúmeras manifestações ocorridas na Espanha desde o 15 de maio de 2011, e também, pois as lutas do $25 \mathrm{~S}$ apresentaram elementos singulares no caso espanhol.

O que nos interessa no $25 \mathrm{~S}$ é a composição heterogênea, aberta, em constante movimento dos coletivos envolvidos; o que impede o endurecimento identitário facilmente identificável. Mas mais importante neste texto é o fato de que o acontecimento revela uma outra singularidade de indignação espanhola: a população. No $25 \mathrm{~S}$ um senhor enfrentou sozinho a polícia para defender manifestantes, fato que será apresentado de forma sistematizada no texto. Pensamos que isso teria sido feito por qualquer pessoa da população. Assim, percebemos que há uma indignação que extrapola os sujeitos e coletivos que participam de forma mais consistente nas manifestações e nas atividades constantes produzidas pelos nós das lutas espanholas. Podemos chamar, portanto, os indignados de multidão, como esta é conceituada por Antonio Negri (2005; 2006): todos os que vivem sob o domínio do poder, que têm suas vidas exploradas, e mais, os sujeitos de resistência que desejam outra realidade.

O conceito de Multidão de Negri e o conceito de Devir de Deleuze são centrais em nossa pesquisa intitulada Devires Minoritários do Movimento 15 de Maio. Neste artigo deixamos um pouco de lado o eixo teórico e partimos para uma análise mais empírica. No entanto, os conceitos estão sempre presentes de uma forma ou de outra. Neste texto temos como conceito principal o de "entusiasmo para com a revolução" de Kant, ou melhor, como este foi apropriado por Foucault.

Quanto à aproximação do empírico ela é dividida no artigo em duas vias: primeiro, off line, se refere a contatos que tivemos com os indignados em viagem feita para Espanha em 2011. Mesmo que o acontecimento seja do ano posterior, nossa experiência of line na Espanha nos ajuda a pensar o desejo de revolução da população. Na Espanha, participamos de eventos diferenciados, como assembleias, encontros de coletivos, além de termos feito entrevistas com sujeitos atuantes nas lutas. A segunda via, mais importante até o momento para a pesquisa, se refere às produções na web feitas pelos indignados, que usam exaustivamente as redes para difundir informações, e nós as usamos como forma de reconstruir os acontecimentos. Também as produções das mídias de massa nos ajudam, pois as estamos percebendo como representantes dos indignados, mesmo que seja de forma parcial. 


\section{O 25S - Primeira parte}

O 25S, que iniciou em 25 de setembro de 2012 e se desenrolou até o dia 29, apresentou uma imprevisibilidade caótica, tanto na reunião de inúmeros grupos sem uma identidade afirmada, quanto na transformação da composição destes grupos. Importante detalhar que toda essa imprevisibilidade não impediu que a manifestação acontecesse de forma auto-organizada, sendo o caos produzido pela máquina bem estruturada, burocrática do poder político e seus "cães de guarda", a polícia. Como declara o informativo alternativo Kaos Em La Red:

Madrid ha sido un campo de batalla. Policías con armas largas en lo alto de las azoteas en torno al Congreso de Diputados. Detenciones arbitrarias e identificaciones a ciudadanos que deambulan por las calles sin razón alguna. Porras, patadas, alones de pelos y cuanta cosa sirva para golpear a los indignados de este gran país, de esta gran ciudad. Ataques y detenciones selectivas para fragmentar la ira y el dolor de un pueblo que clama por un cambio de ruta y de principios. "Antidisturbios" que pisotean cuerpos, cabeza o brazos, para anular y amedrentar a los que exigen una ruta diferente. La dignidad está efervescente en las calles. [...] Madrid se crece ante la fuerza bruta. (www.kaosenlared.net)

O 25S reuniu pessoas indignadas com o poder, que estiveram presentes para expressar isso, a partir de palavras de ordem, cartazes, registros midiáticos, cantos e panelaços. Obviamente, como não estavam lá para uma partida de críquete, nem para um show de música pop, como estavam lá para demonstrar indignação, seus coros, palavras de ordem, dizeres não eram "recadinhos amorosos" para o governo, mas expressões do desejo do fim, da morte do sistema.

Tudo ocorreu razoavelmente, sem sinais de violência da parte dos indignados; a violência foi gerada, como dissemos, pela polícia, exatamente aqueles que são contratados para manter a paz, a tranquilidade dos cidadãos. Mas não no $25 \mathrm{~S}$ como em muitos outros acontecimentos: a polícia gerou o caos entre a multidão, a atacou sem piedade, para defender o poder.

Nos últimos anos é comum a postagem de imagens e textos expondo as táticas da polícia de literalmente, gerar caos em manifestações: reúnem policiais jovens de ambos os sexos; esses se vestem como os jovens indignados, 
muitas vezes de negro, com capuzes ou lenços para esconder o rosto. Então, começam a praticar ações de violência.

Um caso ganhou certa repercussão nas redes sociais e pode ser contemplado em vídeo postado no youtube (www.youtube.com). Nele policiais fardados e policiais a paisana, na demonstração do dia 26 de setembro, detêm um homem de preto, o derrubam no chão, e ele grita: "sou companheiro, sou companheiro". Os policiais dizem: "este é companheiro"; ou seja, era mais um policial infiltrado que estava causando confusão na demonstração e que não havia sido reconhecido.

Outras imagens em vídeo mostram algo parecido, agora no dia 25 de setembro (www.youtube.com). Nas legendas do vídeo, diz-se que sujeitos que começaram um tumulto na demonstração eram policiais infiltrados: um grupo de encapuzados, que usavam símbolos da esquerda como bandeiras vermelhas e negras.

Nas lutas que aconteceram nos dias 25, 26 e 29 de setembro em Madrid, milhares de manifestantes se reuniram em frente ao congresso. A intenção dos manifestantes não era totalmente clara, sendo modificada ao longo das preparações, mas inicialmente, a ideia era impor ao congresso "[...] a la elaboracion de una nueva Constitucion (tomando en parte como inspiracion el modelo historico de las revoluciones liberales), que iria precedida de una "destitucion" del gobierno actual." (Comisión de Análisis Sol 15M, p. 3). Um dos teóricos dos indignados, Victor Sanpedro, em artigo, expressa outras demandas dos nós que compuseram o $25 \mathrm{~S}$ :

[...] se pide más democracia. Se impugna el desmantelamiento del muy precario Estado de Bienestar y la precarización de la fuerza de trabajo que comparten ambos partidos. Y se critican los giros pendulares que impiden la continuidad de políticas centrales para una sociedad (sanidad, educación, organización del estado...). (Sanpedro, 2012)

Também outro meio de comunicação publica um longo artigo com muitas informações extraídas das redes sociais dos coletivos que compuseram a preparatória, apresentando o seu ideário:

[movimento] "de carácter social, antineoliberal, anticapitalista y democrático", [luta] por la soberanía, una democracia directa y parcipativa, donde las necesidades básicas de las personas estén cubiertas y donde 
caben valores como: el reparto de la riqueza equitativo, el rechazo rotundo a la Guerra, la convivencia con el medio ambiente, la denuncia de la explotación, la justicia y reparación histórica, la no mercantilización de la totalidad de los recursos, el apoyo a la emancipación y soberanía de los pueblos, la defensa a las personas migrantes y la oposición a políticas de alianzas con el liberalismo capitalista, recogiendo las diversas corrientes ideológicas antes citadas. (http://iniciativadebate.org

Aqui importante frisar que a imposição de mudanças macro, de certas demandas frente ao governo, que nunca são atendidas, mesmo mediante manifestações em massa, isso não se sobrepõe ao processo revolucionário expresso na tomada das ruas. Assim, o bloco de manifestações que ocorrem periodicamente, cria um território rico em si mesmo, produzido a partir da indignação da população. Dizemos isso, pois nosso objetivo na pesquisa é mapear o devir revolucionário dos indignados, seus processos, sua riqueza atual, o que está acontecendo e não tentamos pensar no que vai acontecer, o futuro da revolução, se o governo vai atender as exigências dos coletivos.

As fontes oficiais dizem que nos momentos mais expressivos havia seis mil pessoas; outras fontes de mídias corporativas falavam em algo entre 50 e 100 mil pessoas. Fontes do movimento calcularam entre 20 e 60 mil pessoas. Vimos muitas fotos e imagens panorâmicas em vídeo. A Praça Neptuno, próxima ao congresso, estava repleta de uma massa densa.

Em informe publicado na página de um dos nós mais importantes das lutas na Espanha, a Acampada Sol, é exposta a preparação para o acontecimento e declarada a indeterminação da organização da convocatória. O primeiro grupo a dar o empurrão inicial foi a Plataforma em Pie, que segundo o documento era formada por inúmeros coletivos: "Un grupo de activistas que trabajamos en distintos colectivos (15M-Dry, DDHH, PAH, III Republica, Constituyentes,...) nos hemos reunido en un frente comun para llevar a cabo esta accion, 25S 'Ocupa el congreso'.' (Comisión de Análisis Sol 15M, p. 1). Também é dito que essa informação não era precisa "Mas tarde, esta informacion se borro. Tambien se sugirio en varias ocasiones que se trataba de gente relacionada con Anonymous, aunque la informacion que circulaba era contradictoria." (Comisión de Análisis Sol 15M, p. 1).

Em documento da própria Plataforma em Pie, o coletivo se apresenta de forma mais explícita dizendo quem está envolvido na sua composição: 


\begin{abstract}
Somos personas reunidas en un movimiento de carácter social, antineoliberal, anticapitalista, antipatriarcal y democrático. [...] En esta plataforma confluyen diferentes sensibilidades representadas en diversas corrientes de opinión y movimientos sociales, entre las que se incluyen: Corrientes republicanas de izquierda, Corrientes de izquierda social, Corrientes libertarias, movimiento $15 \mathrm{M}$, movimiento antiglobalización, corriente antipatriarcal, movimiento obrero, movimientos ecologistas... (http://plataformaenpie.wordpress.com)
\end{abstract}

Estes "inician la difusión de la misma desde el anonimato y por Facebook inicialmente. Mas tarde crean el blog de la Plataforma y una cuenta en twitter, pero evitan en todo momento decir quiénes son (en parte por miedo a la represion)." (Comisión de Análisis Sol 15M, p. 1). O documento também dá importância para um segundo momento da preparação e convocatória do acontecimento, a criação da Coordinadora 25S, esta mais aberta, que traz novos objetivos para a demonstração programada.

Cabe destacar que a Coordinadora $25 \mathrm{~S}$ se mantém bem ativa nos meses posteriores, e ainda há atualizações em seus canais de informação. Nos cadastramos na página da Coordinadora (http://coordinadora25s.wordpress.com) e recebemos via e-mail informações. Desde setembro de 2012, as atualizações são frequentes, às vezes, acontecendo hiatos nas postagens. Quanto a Plataforma en Pie, ela foi posteriormente, dissolvida; ou seja, durou um pouco mais de um semestre.

Creemos que llegado un momento determinado todo movimiento debe evolucionar o ser superado y que en nuestro caso ha llegado el momento de parar y de replantearnos la dirección a seguir. Aunque la plataforma cese indefinidamente su actividad, la lucha debe seguir, y animamos a que así sea y que se pongan en marcha iniciativas de resistencia que puedan sorprender y desafiar al régimen.

(https://plataformaenpie.wordpress.com)

Interessante que no mesmo comunicado declara-se que a dissolução do coletivo pode ser efêmera, o que confirma ainda mais toda a indeterminação que envolve a organização da plataforma e assim da composição das lutas na Espanha:

La Plataforma se reactivará de nuevo si se da alguno de los siguientes casos: a) Que tengamos una nueva propuesta que aportar, que pueda 
ilusionar y despertar a la sociedad, acercándonos al cambio deseado. b) Que el rumbo de los acontecimientos se precipite y la sociedad se muestre verdaderamente dispuesta a presentar batalla. En este caso pondremos todos los medios a nuestro alcance para apoyar y empujar la ruptura y el cambio. (https://plataformaenpie.wordpress.com)

Muitos meios fizeram a cobertura do $25 \mathrm{~S}$ a partir de notícias minuto a minuto. Abaixo expomos o que foi dito no site La Haine (www.lahaine.org), que traz notícias de movimentos de resistências contemporâneos. Já no início das postagens diz que muitos ônibus estavam vindo de outras localidades pra acudir a manifestação. "Cabe destacar que varios autobuses que llegaban a Madrid desde distintos puntos del Estado han sido bloqueados a la entrada de la ciudad.". As 15:00h, segundo o La Haine, próximo do local das manifestações posteriores havia uma concentração com comidas populares: "La convocatoria se desarrolla ahora en el Paseo del Prado, donde tiene lugar una comida popular. Hasta aquí ha venido la gente desde Atocha y desde Plaza de España, los dos puntos donde recibieron a los manifestantes llegados de otras ciudades.". Também outras cidades estavam fazendo demonstrações como em Sevilha, com "unas 3000 personas, convocadas por el SAT, rodean el Parlamento andaluz. Los participantes avisan: "O nos dejan entrar o entramos a las bravas"." Já no local das manifestações em Madrid, por volta das 19:30 "los antidisturbios, con casco y escudo, han empezado a cargar contra la gente que se agolpaba junto a las vallas.” Das 21:00h até a 1 h do outro dia toda a narrativa é referente a cargas policiais. Retornaremos a esse dia e horário final na última parte do texto, na qual tratamos do caso do Bom Homem do 25S.

\section{O 25S - Segunda parte}

Continuando a narrativa, agora centramos no último dia do acontecimento que começou em 25 de setembro. É declarado na página do El Pais: "La protesta del 25-S vuelve a la plaza de Neptuno. Tras la manifestación que se saldó con 35 detenidos y más de 60 heridos, los convocantes han vuelto a llamar a los ciudadanos a protestar". (http://politica.elpais.com)

La Coordinadora 25-S ha convocado una nueva protesta a partir de las seis de la tarde en Neptuno (Plaza de Cánovas del Castillo) y la Puerta del Sol con el objetivo de volver a rodear el Congreso por tercera vez 
esta semana y pedir la dimisión del Gobierno y el inicio de un proceso constituyente. Esta tercera protesta se produce a pesar de que la juez de Instrucción número 8 de Madrid haya considerado que "existen motivos bastantes"para estimar que los detenidos durante la primera protesta del pasado 25 de septiembre cometieron un delito contra las Instituciones del Estado. El próximo lunes decidirá si se inhibe a favor de la Audiencia Nacional. (http://politica.elpais.com)

Imagens no streaming do El Pais, agora já na mobilização, servem como nosso ponto de partida na construção da narrativa: imagens panorâmicas dão uma visão ampla da multidão, toda a praça repleta de gente, cantando, apitando, fazendo batucada. Cantam "televisão, manipulação". Cornetas tocam. Há um murmúrio alto de pessoas conversando. Muitos cartazes escritos: "Não". O Não que marca as palavras de ordem do movimento: "Não nos representam", "Não hay pan para tanto chorizo". Frases estas que também percorrem as redes sociais. Um furgão com pessoas em cima, bem no centro da manifestação. Melhor estar na manifestação, vivê-la sem distanciamento, e depois de vivê-la pegar os dados na web. Porém, na impossibilidade de estar em uma demonstração, estar na web possibilita uma narrativa de outra natureza.

Parece uma festa, só que perigosa; estão todos de frente para uma massa policial, bem armada. Sabem que pouco podem fazer frente à repressão, pois o poder da polícia tenta ser absoluto e mais, acima da própria lei. Os jovens gritam "demissão, demissão" Alguém fala em um alto falante ou megafone, puxa palavras de ordem. Parece que a polícia está mais organizada que nos dias anteriores, a grade que separa manifestantes e os representantes do governo está mais fortificada.

Muitos assobios, cantos. Parece de cima um show, todos de frente ao congresso, onde está a polícia e a grade. Três jovens sobem nos ombros de outros, ficam de pé, o que gera alguns gritos de ovação; os jovens se abraçam para não perder equilíbrio, mas também como gesto fraterno. Os garotos abrem uma bandeira espanhola. Aliás, há várias bandeiras da Espanha sendo empunhadas.

Estávamos com o tablet ligado no streaming do El Pais. Com o notebook, estávamos conectados no twitter que apresentava comentários sobre o que es- 
tava passando; no facebook, apareciam alguns comentários e links, como também fotos que eram postadas em perfis.

Outros cartazes nas imagens ao vivo: "repressão, censura, tortura." "Não somos maquinas, não somos gado, somos homens" Um cartaz com o símbolo da paz virado. Outros cartazes: "divida odiosa, referendo já", "banqueiro bom é banqueiro morto", "ao governo lhe agrada quando tu te calas", "pensa, se organiza e luta", "menos Franco e mais pão branco". Outros cartazes com números dos desempregados na Espanha, comparando com outros países da Europa. "Democracia é diferente de ditadura de quatro anos". Em certos momentos, gritos em massa, um som parecido com um mantra. Uma figura vestida de negro, alta, um circence, talvez representando a morte dos governantes, ou do povo pelas medidas.

No fim da demonstração, começamos a receber informações de que haveria uma assembleia para fechar a manifestação. "Atencion: ha empezado la asamblea en Neptuno. Las personas q estais delante frente al congreso acercaros al lateral d cibeles." (@ democraciareal). A primeira coisa que é feita na assembleia é a leitura de um manifesto.

A assembleia, nós contemplamos via streaming no site Bambuser (http://bambuser.com). A mídia apresentava boas imagens, sem cortes, o que nos permitiu uma visão geral, com alguns detalhes. Relatamos o que foi dito sem nomear os sujeitos, pois isso não foi feito, apenas abria-se espaço para quem desejasse falar. Na sequencia cada sujeito será referenciado por números. Antes de começar as falas já programam uma outra assembleia para o dia seguinte. 1. Sugere trabalhar localmente. 2. Incita medidas efetivas, luta real, não virtual, luta pacífica. Todos aplaudem. 3. Importante pensar nas pessoas que não vivem em Madrid e não podem acudir as demonstrações. Todos aplaudem. 4. Fala da importância dos meios e em não reforçar os meios corporativos. Todos aplaudem. 5. Abrir processo constituinte para unificar as lutas sociais em um processo participativo, que se difunda para os bairros e assembleias populares. Fazer a constituição com as próprias mãos. Aplausos. 6. Declama uma poesia sobre o gênero humano e a beleza do comum da vida. Fala sobre amor, o governo do amor. Todos aplaudem. 7. Um mediador fala, todos aplaudem e sorriem.

Percebemos uma leveza nas palavras, nos sorrisos, nas vozes, todos unidos, muito diferente da seriedade da macropolítica. Sente-se um certo descompromisso que diz respeito à juventude, um amor pela vida, longe do can- 
saço imposto pelo poder. E todos passaram o dia todo em luta na demonstração, de pé, cantando, agindo, com os nervos a flor da pele, pois a polícia estava lá, sempre pronta para acabar com a alegria; e todos estavam ali na assembleia, entre risos, aplausos, mostrando boa vontade, amando os seus. Longe de todo estresse, a possibilidade do desemprego, a pobreza muito próxima, o fim dos sonhos, mesmo assim todos cultivando a alegria. Uma forma jovem de encarar a vida.

No Twitter umas últimas palavras sobre a assembleia e decisões do que fazer daqui pra frente: "Ha terminado la asamblea. Gracias a todas las personas q habeis venido a luchae $\mathrm{x}$ una democracia real. Nos vemos mañana $\mathrm{n}$ el retiro 11h.” (@ democraciareal). "El \#30s habrá otra asamblea en el retiro. Se debatirán decisiones sobre la continuidad...” (@Voces25S ).

\section{O bom homem do $25 \mathrm{~S}$}

No $25 \mathrm{~S}$ um fato inusitado aconteceu e depois se tornou tema de uma cobertura em massa, em periódicos, nas redes sociais e principalmente, no youtube. Foi, aliás, o youtube que fez a primeira difusão do fato. Após a manifestação, grupos de pessoas ainda permaneciam nas ruas ao redor do congresso. A polícia começou a cargar contra os manifestantes. As imagens que vimos no youtube e que infelizmente, foram retiradas da rede, mostravam um grupo grande de jovens que entra em um bar para não ser abordado por policiais. Estes, os policiais, tentam entrar no bar, porém um senhor de 50 anos de idade, que trabalhava no local, grisalho, bem acima do peso, desesperado os impede. Ele posteriormente, foi chamado de "O Bom Homem do 25S".

Em outro vídeo postado no youtube (www.youtube.com), o "bom homem" fala na frente das câmeras, junto à porta na qual defendeu com seu corpo os manifestantes. Ele diz que os manifestantes são os heróis, não ele, porque ele não teve coragem para ir as ruas na demonstração. Pessoas apertam suas mãos, tiram fotos com ele. Segundo as legendas do vídeo, muitos caíram em lágrimas na homenagem; as imagens mostram uma jovem o abraçando e chorando. Pessoas aplaudem. Ele diz: aqui, o bar, é a casa de todos, não tem que ter colhões para entrar.

Interessante que o "bom homem" vira herói tanto do lado dos indignados, quanto da mídia dominante. O homem mais velho, barrigudo, um fraco, que defende outros mais fracos ainda contra a polícia. Ele um simples homem 
do povo, que não foi para as ruas. O mais importante do fato é que podemos conectá-lo com um conceito, o de "entusiasmo para com a revolução" de Foucault.

O texto que Foucault (1984) trata desse "entusiasmo" ou "predisposição para o bem" é um texto curto centrado nas considerações de Kant sobre seu presente, melhor, sobre o acontecimento mais marcante de sua contemporaneidade, a Revolução Francesa. Esse texto já havia nos chamado a atenção no início da pesquisa, quando fizemos relações entre ele, o desejo de multidão e os indignados. Essas relações tomaram consistência em nossa passagem por Barcelona em 2011. Algo nos chamou a atenção e motivou essas relações, algo que nos forçou a pensar. Esse algo ouvimos em uma assembleia, em uma conversa no primeiro contato com indignados e também em um encontro de um coletivo de Barcelona, o AgoraBCN. Notamos nos discursos uma divisão entre as pessoas que saem as ruas e as supostas pessoas que nada fazem contra a crise, um corte no interior da população espanhola. Ouvimos coisas do tipo: "eles ficam em casa vendo televisão, tomando cerveja, enquanto nós estamos na rua apanhando da polícia". "Caminham feito uma manada bovina nas ruas e nada fazem". Ou falas menos duras, como: "nós [o povo] fomos muito bem educados, precisamos ser indisciplinados [...] mas nós [os indignados] nas ruas praticamos a insubmissão voluntária".

O discurso é compreensível, é duro sair às ruas na busca de um mundo melhor para todos, mundo em que não há centros de poder, transcendência, corte entre dominantes e dominados, enquanto a maioria simplesmente, nada faz, ou melhor, faz o jogo do poder em seu silêncio, apoiando o governo. As palavras de Reich lembradas por Deleuze e Guattari (1972) são convenientes: como entender que as pessoas não lutem por uma vida melhor, por qual motivo desejam a repressão? Porém, precisaríamos de uma percepção fina, para entender como os próprios indignados fazem o jogo do poder, despotencializando as lutas nesse tipo de discurso que pode culminar em um derrotismo, e, mais, como "a tal da manada" pode impulsionar as lutas.

Falávamos com um atuante em um coletivo sobre a função da mídia corporativa no auxílio às lutas, e que no El Pais foi exposta a porcentagem do povo espanhol que simpatizava com os indignados, mais de $80 \%$. Ele me disse que pensava que isso era verdade, mas que esses $80 \%$ não estavam nas ruas e por isso nada significavam. No entanto, será que os discursos de pais, mães, avós, vizinhos, parentes, amigos, de pessoas mais velhas, de todos que 
demonstram sua insatisfação com a democracia representativa e com o capitalismo, ou seja, que desejam mesmo que de forma inconsciente uma realidade menos dura, que talvez seja a real democracia, será que isso não é um dos estopins das lutas na Espanha?

Assim, indignados seriam todos os que vivem sob o domínio do capital, que têm sua produção apropriada, que são obrigados a aceitar o modelo político dominante como se fosse a única possibilidade. Se indignados são todos e não apenas uma parcela dos espanhóis, mas todos os que vivem sob o poder, a multidão, a multidão de indignados, a coisa muda de figura e se torna realmente potente.

Aqui vemos a potência revolucionária possibilitada até por aqueles que são passivos à primeira vista. A potência da manada se atualiza quando se torna multidão; pensamos a potência em termos de desejo, desejo de revolução, de mudança, de uma vida melhor. O desejo pensado como entusiasmo, em Kant, para a revolução, mesmo daqueles que não lutam diretamente.

Foucault faz uma resenha inicial de parte do pensamento de Kant

Se se quer responder à questão "Existe um progresso constante no gênero humano?" é necessário determinar se existe uma causa possível desse progresso, mas, uma vez estabelecida essa possibilidade, é preciso mostrar que essa causa atua efetivamente e, para isto, realçar um certo acontecimento que mostre que a causa atua realmente. [...] Não é suficiente que se siga a trama teleológica que torna possível o progresso, é preciso isolar, no interior da história, um acontecimento que tenha valor de signo. Signo de que? Signo da existência de uma causa, de uma causa permanente, que ao longo de toda a história guiaram os homens pela via do progresso. Causa constante da qual se deve então mostrar que agiu outras vezes, que atua no presente e que atuará posteriormente. (Foucault, 1984, p 6-7)

Esse signo é a revolução. Mas para Kant, o importante da revolução não é o fato de ser um grande acontecimento, com suas inversões de poderes, com as quedas de símbolos, mudanças desejadas e que por isso ela é feita. Para Kant, tudo isso acontece a partir de uma violência tal que acaba sendo indesejada. Não se faria novamente, a revolução, sabendo de seus efeitos.

[...] o que faz sentido e o que vai constituir o signo do progresso é que, em torno da revolução, diz Kant, há "uma simpatia de aspiração que 
beira o entusiasmo". O que é importante na revolução, não é a revolução em si, mas o que se passa na cabeça dos que não a fazem ou, em todo caso, que não são os atores principais; é a relação que eles mantêm com essa revolução da qual eles não são agentes ativos. O entusiasmo para com a revolução é signo, segundo Kant, de uma disposição moral da humanidade [...] (Foucault, 1984, p. 9)

Ou seja, o entusiasmo para com a revolução expressa o desejo de insubmissão, a insubmissão voluntária. O mais importante do texto de Foucault sobre Kant é a possibilidade de ampliar os sujeitos de luta na Espanha. E perguntamos: como perceber o entusiasmo para com a revolução do povo espanhol? Para nós isso fica visível nos relatos das acampadas - as tomadas de praças na Espanha, o primeiro momento das lutas no país - quando pessoas que não estavam acampando traziam suprimentos; quando as pessoas que trabalhavam no comércio do entorno colaboravam. Também fica visível na simpatia do povo espanhol para com os indignados, visto em pesquisas de opinião; como diz Castells:

Así, según la encuesta de Metroscopia publicada por El País, el 66\% de los ciudadanos tienen simpatía por el $15-\mathrm{M}$, el $81 \%$ piensa que los indignados tienen razón y el $84 \%$ que tratan de los problemas que afectan directamente a los ciudadanos. El 51\% piensa que los partidos representan sus propios intereses. El $70 \%$ no se siente representado por ningún partido y el $90 \%$ piensa que tienen que cambiar. Los votantes socialistas simpatizan con el movimiento en un $78 \%$, pero también lo hace el $46 \%$ de los votantes del PP. (Castells, 2011)

Ou seja, o entusiasmo, em um primeiro momento, referente à simpatia com os indignados. Um outro sinal é a saída da passividade a partir de uma ação indignada, a do "bom homem", que agiu revolucionariamente. Pôs seu corpo e estabelecimento em risco. Pelo seu olhar e gestos desesperados sabia que poderia ser agredido pela polícia ou preso; sabia que os seus, os jovens poderiam ser presos, contra o que ele lutava, ele estava predisposto para o bem da revolução. 


\section{Considerações finais}

Como em todos os acontecimentos massivos a rotina se manteve: se fez a preparação nas redes comunicativas e houve o êxito de atualização dessas preparações nas ruas. A multidão tomou o espaço urbano. O pacifismo foi um dos elementos principais, mas mesmo assim a polícia foi extremamente, violenta. O elemento diferencial que percebemos no acontecimento nos possibilitou ampliar o conceito de indignados; este não referido apenas as pessoas que saem para as ruas ou que participam da organização dos coletivos, pois pensamos a população como singularidade de indignação.

\section{Referencial teórico}

Castells, M. (2011). Después de la acampada. La Vanguardia. Disponível em: www.lavanguardia.com. Acesso em: 20 jul. 2013

Deleuze, G. \& Guattari, F. (1972). O anti-Édipo: capitalismo e esquizofrenia 1. Trad. Luiz B. L. Orlandi. ed. 34.

Foucault, M. (1984). O que é iluminismo?. Disponível em: http://pt.scribd.com. acesso em: 15 mai. 2013.

Hardt, M. \& Negri, A. (2005). Multidão. Rio de Janeiro: Record.

Hardt, M. \& Negri, A. (2006). Império. Rio de Janeiro: Record.

Sampedro, V. (s.d.) El 25S ha triunfado. Público.es. Disponível em: http://blogs.publico.es. Acesso em: 20 jul. 2013

\section{Documentos da web}

Bambuser: http://bambuser.com

Comisión de Análisis Sol 15M. Informe sobre el 25S. disponível em: http://madrid.tomalaplaza.net. Acesso em: 15 mai. 2013.

Coordinadora 25S: http://coordinadora25s.wordpress.com

El Pais. Directo disponível em: http://politica.elpais.com acesso em: 15 mai. 2013.

Iniciativa debate. El movimiento 25S "ocupa el Congreso": antecedentes, desarrollo y censura en los media mass españoles. Disponível em: http://iniciativadebate.org. Acesso em: 20 jul. 2013. 
La Haine. Actualización 00.50: Desalojan Neptuno tras una última carga. Disponível em: www.lahaine.org. Acesso em: 15 mai. 2013.

Plataforma en Pie. Serie de comunicados post 25A - Comunicado $\mathrm{N}^{\circ} 3$ (Disolución de la Plataforma ¡En Pie!). Disponível em:

https://plataformaenpie.wordpress.com. Acesso em: 20 jul. 2013

Plataforma em Pie. Documento Base. Disponível em: http://plataformaenpie.wordpress.com. Acesso em: 15 mai. 2013.

Kaos en la Red. (VÍDEOS) Madrid, haciendo historia. Disponível em: www.kaosenlared.net. Acesso em: 20 jul. 2013

Youtube. 26S El Buen Hombre 26 septiembre 2012. Disponível em: www.youtube.com. Acesso em: 15 mai. 2013.

Youtube. 26s infiltrados de la policia "coño que soy compañero". Disponível em: www.youtube.com. Acesso em: 20 jul. 2013.

Youtube. Infiltrados de la policía quedan en evidencia \#25S. Disponível em: www.youtube.com. Acesso em: 20 jul. 2013

Wikipedia. Primavera Árabe. Disponível em: http://es.wikipedia.org. Acesso em: 16 jul. 2013. 


\title{
Poética Literária e Poética Cinematográfica: Um Confronto nas Terras Médias de O Hobbit
}

\author{
Vanda de Sousa \& Cristina Ponte \\ Universidade NOVA de Lisboa \\ E-mail: vandamariasousa62@gmail.com/cristina.ponte@fcsh.unl.pt
}

\begin{abstract}
Resumo
Este artigo enquadra-se num estudo mundial sobre audiências da trilogia The Hobbit cujos resultados serão analisados em 2015-2016. Enquadrando e antecipando essa análise dos resultados, o artigo introduz uma das questões de pesquisa: se (e como) é a relação dos espetadores com a adaptação cinematográfica de Peter Jackson marcada pela sua leitura anterior dessa obra literária de J.R.R. Tolkien.

adaptação ao cinema da obra $O$ Senhor dos Anéis, do mesmo autor, e a resposta das audiências a essa trilogia, o artigo confronta a relação da literatura com o cinema, entre a posição tolkieana expressa no ensaio On Fairy-Stories (1938-39) e no conto Leaf by Niggel (1947), por um lado, e as novas possibilidades proporcionadas pelas tecnologias cinematográficas digitais, por outro.
\end{abstract} Apresentando pesquisa anterior relativa à

Palavras-chave: Tolkien; contos de fadas; fantástico; poética literária; cinema digital; audiências de cinema.

\section{Poetic Literature and Film Poetics : A Confrontation in the Midlands of The Hobbit}

\begin{abstract}
This article is part of the global study on the audiences of The Hobbit trilogy, whose results will be analyzed in 20152016. Framing and preparing the further analysis, the article introduces one of the research questions: whether (and how) is the reception of the movie directed by Peter Jackson affected by the previous rea-

ding of the J.R.R. Tolkien's novel. Recalling previous research on the adaptation of Tolkien's novel The Lord of the Rings to the cinema, and its reception ten years ago, the article discusses the relation between literature and cinema, between Tolkien's points of view expressed in $O n$ Fairy-Stories (1939-39) and in the story
\end{abstract}


Leaf by Niggel (1947), on the one hand, and the new possibilities offered by digital cinema technologies, on the other.

Keywords: Tolkien; Fairy Tales; Fantastic; Literary poetic; digital cinema; movie audiences.

\section{O Hobbit uma história para crianças? Um conto de fadas? Uma história fantástica?}

"Num buraco do chão vivia um hobbit. Não se tratava de um buraco húmido, sujo e desagradável, cheio de restos de vermes e com cheiro repugnante, nem tão-pouco de um buraco arenoso, nu e seco, sem nada para uma criatura se sentar ou em que comer: era um buraco de hobbit, e isso significa conforto."

(Tolkien, 2007:12)

$\mathrm{E}^{\mathrm{M}}$ 1958, John Ronald Reuel Tolkien (1892-1973) foi contactado por Forest Ackerman que lhe pediu que lesse a sinopse escrita por Fred Zimmerman com vista a adaptação para cinema da obra $O$ Senhor dos Anéis. Tolkien reagiu negativamente à proposta de adaptação - o que para o escritor era uma história passada num tempo mitológico, em que homens e seres fantásticos se empenhavam numa demanda para destruir o mal, Hollywood interpretava como uma simples história para crianças. E assim se gorou a primeira tentativa para adaptar ao grande ecrã da sala de cinema um texto de Tolkien.

A obra $O$ Senhor dos Anéis teria diversas adaptações para Rádio e Televisão, algumas das quais em vida do escritor (1892-1973). Entre 1955 e 1956, a BBC emitiu uma adaptação da obra para Rádio, em doze partes, das quais nenhuma foi preservada. Em 1981, a BBC voltaria a emitir nova adaptação a Rádio, com a duração de 26 horas e meia. Em 1979, foi a vez de os Estados Unidos produzirem nova adaptação a Rádio; a obra seria preservada em fita magnética e, posteriormente, editada em CD. Para Televisão, em 1980, O Senhor dos Anéis conheceu uma adaptação parcial (O Retorno do Rei); tratava-se de um desenho animado assinado pelos estúdios Rankin-Bass que, em 1977, tinham já produzido uma versão semelhante de $O$ Hobbit. Com um custo de três milhões de dólares, essa versão de $O$ Hobbit tinha como atrativo 
o contar com as vozes de atores como Otto Preminger (Elveking), Richard Boone (Smaug) ou John Huston (Gandalf). O especial televisivo foi adaptado por Romeo Muller e produzido por Arhur Rankin e Jules Bass, tendo sido exibido pela NBC, a 27 de Novembro de 1977, um domingo.

Para Cinema, O Senhor dos Anéis foi adaptado, em 1978, em desenhos animados, por Ralph Bakshi. Nesse ano, Romeo Muller adaptou a Cinema a versão televisiva de $O$ Hobbit e concorreu ao Hugo Award for Best Dramatic Presentation, tendo perdido para o filme Star Wars, escrito e realizado por George Lucas em 1977.

Décadas mais tarde, Peter Jackson, o produtor e realizador neozelandês, relançaria a polémica da adaptação ao Cinema quando, em 2001, estreou a primeira parte de $O$ Senhor dos Anéis ${ }^{1}$, alcançando o que antes era impensável: uma popularidade igual à de Star Wars ou The Godfather ${ }^{2}$. Contudo, permanece a questão de se saber se Tolkien considerava (ou não) a adaptabilidade da (sua) poética literária à poética cinematográfica.

Salvaguardando as características de $O$ Hobbit que diferenciam o texto de $O$ Senhor dos Anéis - uma certa leveza narrativa, traços humorísticos que, posteriormente, quase desaparecem das personagens - embora pudesse ser endereçado a uma literatura infanto-juvenil, Tolkien não considerava este texto como tal. De resto, para o escritor, a literatura não é susceptível de se classificar consoante o público leitor. Para compreender este aspeto, faz-se imperativo que se preste atenção à sua concepção de poética literária e às suas funções junto dos leitores - sejam crianças sejam adultos - para o que se convoca a leitura de duas obras suas: o ensaio On Fairy-Stories (1938-39) e o conto Leaf by Niggel (1947) ${ }^{3}$.

O ensaio On Fairy-Stories, publicado pela primeira vez em 1964, foi escrito no contexto de um conjunto de conferências que Tolkien apresentou na Universidade de St Andrews, Escócia, sobre o escritor escocês Andrew Lang (1844-1912), crítico literário e antropólogo com uma vasta recolha de literatura oral, nomeadamente os contos de fadas (fairy tales). Nesse ensaio, mais

1. O Senhor dos Anéis - A Irmandade do Anel, (2001), adaptado por Fran Walsh, Philippa Boyens e Peter Jackson.

2. The Godfather (1972), adaptado por Mario Puzo, e Francis Ford Coppola a partir do romance homónimo de Mario Puzo, realizado por Francis Ford Coppola.

3. Originalmente publicado na Dublin Review, foi posteriormente publicado em 1964 juntamente com o ensaio On Fairy-stories. 
do que apresentar a sua concepção de contos de fadas enquanto género literário no qual inclui o fantástico, Tolkien apresenta a sua concepção de poética.

Antes de discutirmos essa concepção de poética, adiante, vejamos como se posiciona Tolkien sobre o conceito de fantástico e os contos de fadas. Os estudos sobre a fantasia registaram um especial desenvolvimento no século $\mathrm{XX}$ quer enquanto género, quer abordando-a do ponto de vista da teoria psicanalítica e estruturalista. Em geral, as teorias literárias tendem a considerar o fantástico como género e o conto de fadas como subgénero do fantástico, sendo ainda de considerar a distinção entre high fantasy (que propõe um mundo recriado) e low fantasy (que irrompe num mundo quotidiano).

Enquanto Todorov (1975: 24) apresenta o fantástico como espaço intermediário entre o maravilhoso e o estranho, outros autores colocaram a ênfase na sua relação com a mimese, ou seja, a possibilidade de transformação de elementos ou personagens do real em detentores de características irreais que, todavia, mantêm uma ligação ao real como condição de reconhecimento por parte do leitor. Por exemplo, Attebery (1992: 14) defende que a obra de Tolkien é responsável por uma nova versão de fantástico, que teria conferido uma nova coerência a este género, ainda que atribua esta particularidade à influência dos escritores eduardinos. Jackson (2007: 13) argumenta que Tolkien usa a noção de fantasia como um desejo de algo melhor e mais completo e como uma realidade unificada: a fantasia será o lugar da gratificação. Por sua vez, Brooke-Rose (1981: 63) considera que o fantástico não é tanto um género evanescente mas antes um elemento evanescente e, nesse sentido, assume uma posição mais próxima a Tolkien, para quem o fantástico diz respeito à imaginação e deve ser considerado como um "escape" próprio da condição humana.

Com o vitorianismo, à fantasia e aos contos de fadas tinha sido emprestado um pendor gótico que trazia ao texto os fantasmas, a magia, o pesadelo, o horror, ruínas de antigos castelos, masmorras, correntes e a escuridão, elementos que estão presentes em $O$ Hobbit. Contudo, Tolkien define-o como conto de fadas, em acordo com a definição registada, desde 1750, no Oxford English Dictionary, segundo a qual conto de fadas tem origem no francês conte de fées (expressão com data anterior a 1610). Descrito nesse Dicionário como " $a$ tale about fairies; a tale set in fairyland; any of various a short tales having 
folkloric elements and featuring fantastic or magical events or caracteres" 4 , o conto de fadas é assim localizado num local específico e distante, habitado por seres fantásticos e mágicos, e no qual se vive num perigo iminente.

Os contos de fadas remetem-nos assim para um universo imaginário, maravilhoso, onde ocorrem situações e elementos fora do quotidiano, mágicos e sobrenaturais (Tolkien, 2011: 14). Pode não haver a presença de fadas; antes, faz-se presente uma relação entre a magia e o uso de objetos mágicos, assistese a uma proibição a que o herói será sujeito, ao confronto com vilões com poderes mágicos e à superação da tarefa e ao regresso a casa (Tolkien, 2011: 69).

Para Tolkien, as histórias de fadas reportam-se às origens da linguagem humana, traçando caminhos que nos levam a outros tempos, fora do tempo, a outras geografias, fora do espaço (Tolkien, 2011: 38-39).

A definição tolkieana de contos de fadas distingue-se ainda por o autor não lhes atribuir um público específico. Diversamente de outros autores, Tolkien não pressupõe que os contos de fadas se dirijam, exclusivamente, a crianças ou jovens: contos de fadas são para crianças mas são, igualmente, para adultos, mercê do seu efeito mítico e do apelo ao maravilhoso que sentem tanto as crianças como os adultos. Esse apelo ao maravilhoso é experimentado pelos seres humanos dada a evidência da crença literária, entendida não como lugar ou exercício da suspensão da vontade de saber mas, antes, como pacto entre escritor e leitor; um pacto que permite tomar como verdadeiro o que a narrativa propõe, convocando o leitor para um novo mundo (Tolkien, 2011: 40) quer este seja realista quer seja fantástico.

$\mathrm{Na}$ verdade, trata-se sempre de um mundo imaginado, um mundo secundário que é tomado como verdadeiro sempre que o autor consegue manter a coerência interna do mundo proposto - um mundo construído a partir de novas imagens que não existem senão por via da imaginação, a origem de todos os mundos secundários. A expressão fé poética (poetic faith), cunhada pelo escritor inglês Samuel Coleridge em 1817, significa precisamente o pacto que se estabelece entre o escritor e o leitor quando o texto fantástico é criado, tendo ainda um cunho de interesse humano e vagas ressonâncias com a credibili-

4. In www.oed.com (acedido a 14/12/2014). 
dade; esse pacto permite que o leitor suspenda o seu julgamento relativamente à ausência de plausibilidade da narrativa ${ }^{5}$.

Tendo como base a magia, os contos de fadas não se confundem com a ficção científica que tem, na sua génese, os avanços da ciência; antes se aproximam dos contos populares porque estes se socorrem de personagens estáticas (Reis \& Lopes, 2011: 78-86) e porque cumprem o que Propp recuperou como estrutura característica do conto de fadas: aí as personagens têm como função ajudar ou prejudicar o herói que se vê obrigado a abandonar o lar e a empenhar-se numa demanda (Propp, 1978).

Tomando como ponto de partida o mundo real, os contos de fadas convocam-nos para narrativas que se desenrolam em mundos imaginários que são, a um tempo, estranhos e familiares, como Bettelheim especifica: o conto de fadas narra uma história cuja verdade não é a da causalidade, mas antes, a verdade da nossa imaginação (Bettelheim, 2002:150). Ou seja, a fantasia humana cria histórias de mundos insólitos, mundos invisíveis em que os conflitos se obrigam a ter um final feliz (Tokien, 2011:10).

\section{Da necessidade de um final feliz}

O conto de fadas tem, obrigatoriamente, um final feliz para permitir ao leitor recuperar a capacidade perdida, recuperar a visão mais clara dos acontecimentos, assegurando ao herói, que abandona o lar no início da narrativa, o regresso vitorioso a casa no final, tal como Propp nos demonstrou. Assim, o conto de fadas propõe uma viagem circular ao maravilhoso, durante a qual o herói é posto à prova sendo seu dever a superação e o restabelecimento da ordem perdida (Propp: 1978:108).

Também Tolkien defende que o final feliz é obrigatório, como significa o seu uso do termo eucatástrofe, que é o momento em que se dá a reviravolta feliz. Este termo deriva do grego: eu significa bom, justaposto a catástrofe, que vem de katastrephein. A junção significa, assim, uma boa mudança ou alteração brusca dos acontecimentos. A necessidade deste final feliz prendese com a necessidade do leitor saber que tudo terminará bem: mesmo que o herói seja obrigado a sair do lar, seja vítima das circunstâncias e procure um

5. In Coleridge, Biographia Literaria, 1817, Chapter XIV, vide www.gutenberg.org (acedido em 12/12/2014) 
objeto mágico, no final ele regressará triunfante. É a antecipação deste final feliz que induz, no leitor, o escape.

De acordo com Tolkien, a principal função das histórias de fadas seria a recuperação por via do escape, de cada vez que esta narrativa nos permite a aproximação ao material antigo. Em termos tolkeianos, pelo encontro com o unicórnio somos capazes de constatar a beleza e nobreza de todos os cavalos (Tolkien, 2011). Ou seja, este escape não é alienante: A permanência temporária no mundo secundário promove a sensação de estranhamento que, por contraste, provoca a renovação no mundo primário.

Tolkien não nos propõe a fuga do desertor, essa seria a marca da desistência. Antes, convoca-nos à fuga do prisioneiro, aquele que não se contenta com a sua condição e que procura a libertação. Por oposição, não se dar à fuga é conformar-se com os muros e com as grades que nos trazem reféns do mundo moderno e nos afastam da Natureza, que nos confinam a considerar as duras realidades como insuperáveis (Tolkien, 2011). Aqui reside a necessidade do final feliz nos contos de fadas: só assim nos consolam na libertação, só assim terá lugar a eucatástrofe desta escrita, que se opõe à tragédia. Como escreve:

"A alegria deveria ter exatamente a mesma qualidade, se não mesmo a mesma intensidade, que a proporcionada pelo "momento de viragem" no conto de fadas: essa alegria tem o gosto especial de uma verdade primeira (de outro modo não se chamaria alegria). Ela aponta para a frente (ou para trás, a direção não importa), para a Grande Eucatástrofe. A alegria do Cristianismo, a Glória, é do mesmo tipo; mas é eminentemente (infinitamente, se a nossa capacidade não fosse finita) superior e jubilosa..." 6 (Tolkien, 2011).

6. No original: "The joy would have exactly the same quality, if not the same degree, as the joy which the 'turn' in a fairy-story gives: such joy has the very taste of primary truth (Otherwise its name would not be joy). It looks forward (or backward: the direction in its regard is unimportant) to the GreatEucatastrophe. The Christiann joy, the Gloria, is the same kind; but it is pre-eminently (infinitely, if our capacity were not finite) high and joyous.." (Tolkien, 2011:70). 


\section{Tolkien e a poética pela imaginação versus a poética pelo olhar}

No conto Leaf by Niggel, Tolkien estabelece a ligação com o ensaio On Fairy-Stories, ao usar, em sentido alegórico, a figura da árvore ${ }^{7}$. Neste conto, Niggel é um pintor que começa a sua obra numa única folha. A tela vai crescendo e vai desenvolvendo-se até parecer uma árvore e depois, ocupar todo o enquadramento ao seu redor. E, todavia, Niggel está limitado. Não pelo número de folhas mas pelo seu próprio tempo. É que Niggel deverá, inevitavelmente, fazer uma viagem desagradável, à qual não se pode subtrair. Assim, Niggel está limitado pela perspectiva dessa viagem e pelo tempo em que ela se concretizará. Com essa viagem no seu horizonte temporal, Niggel vai pintando até que se vê na necessidade de se socorrer de uma escada: a sua obra era já maior do que ele. E é então que Niggel decide que a sua obra deve conhecer um fim. Maior do que o seu criador, impossível de terminar antes da viagem a empreender, a obra está, assim, terminada, mas não acabada. A obra transcendeu o olhar do artista, transcendeu os diferentes olhares que se lhe dirigem.

Os olhares são aqui tomados como as diferentes interpretações subjetivas de quem se endereça à obra, na construção da trilogia autor, leitor e obra, que se pode expressar pela trilogia conceptual alegoria, aplicabilidade e símbolo. A alegoria reporta para a significação que está condicionada pela intencionalidade do autor, pelo que o texto perde a capacidade de significação criativa; a aplicabilidade é a interpretação que envolve o leitor e a obra, o elemento do texto que possui diversos significados de forma mais ou menos independente da vontade do autor; e o símbolo reporta-se a um elemento do texto, sendo a sua interpretação gerada tanto pelo autor quanto pelo leitor.

Reencontrando Niggel, a árvore é o símbolo do processo de significação que nunca estará completo, que está em mutação de acordo com as diferentes interpretações emprestadas pelas diferentes subjetividades que a consideram; e a viagem é a morte de cada artista, a morte de cada eu.

O conto Leaf by Niggel possui uma segunda interpretação: reportando para a poética literária, o conto propõe a personagem de um pintor, o que nos transporta para as poéticas com suporte visual. É esta relação que pode ser

7. Em On Fairy-Stories, Tolkien usa a árvore para explicar a origem dos contos de fadas que teriam raízes na linguagem humana, tendo-se desenvolvido em diferentes ramos, contudo, a cada ramo assiste a individualidade, mas também a mesma matriz da qual deriva. 
considerada quando nos interrogamos sobre a legitimidade da adaptação da poética literária da obra de Tolkien à poética cinematográfica: para Tolkien, a narrativa e a arte visual (qualquer que ela seja) não se abrigam sob uma coexistência pacífica. A arte visual, inevitavelmente, direciona a obra literária para o condicionamento visual (representativo e individualizado, atualizado a cada representação e a cada representação individualizado).

Tolkien não se referiu ao cinema, a sua opção foi pelo teatro, tanto no ensaio como no conto. É, contudo, inequívoco que o escritor considerava o teatro, e assim toda a poética que se funda no visual e no imagético, como distante da verdadeira literatura. Considerava que a poética literária tinha de apelar ao primevo, ao original e não ao individualizado, sob pena de não alcançar aplicabilidade. Isto é, para Tolkien, de cada vez que a arte é individualizada, à semelhança do que sucede no teatro, está a impedir-se a aplicabilidade que envolve a obra e o leitor. Como dizia Virginia Woolf no ensaio "The Cinema" (Woolf, 2008: 173), a adaptação da personagem Ana Karenina de Tolstoi impede-nos de imaginarmos a personagem a cada vez que é lida, por cada leitor que a lê. A relação entre o cinema e a literatura é um relacionamento que constrói um espaço que subverte a introspecção propiciada pela poética narrativa.

Por outras palavras, a transposição da poética literária para a poética cinematográfica compromete o carácter ativamente imaginário que o texto literário exige do seu leitor, em contraste com a imposição a que o texto cinematográfico dá lugar: ver o texto cinematográfico promove uma imagem representada no ecrã que acompanhará a leitura posterior; da mesma forma, a leitura anterior pode revelar-se diversa na interpretação de cada sujeito quando comparada com a leitura que o realizador fez do texto literário com vista à sua transposição para texto cinematográfico. Vale dizer que "literatura e cinema constituem, portanto, artes de poética compositiva inerentemente distintas entre si, o que requisita, de seus respetivos estudiosos e apreciadores, a devida atenção às implicações e impactos subsequentes às adaptações" (Vieira, 2013:1726).

A questão da transposição da poética literária para a poética cinematográfica, isto é, a questão da adaptação tal como é reconhecida no seio dos estudos fílmicos, torna-se tanto mais pertinente quanto a poética literária reporta, como no caso das obras de Tolkien, para um mundo imaginário, para personagens, ambientes e temporalidades que não convocam, diretamente, referenciais reais: Bilbo Baggins é um hobbit. Mas já alguém viu um hobbit? 
Como vimos, as personagens que vivem narrativas fantásticas transportam-nos para tempos, espaços e criaturas que não encontram paralelo no quotidiano do leitor. Assim, cabe ao leitor imaginá-las ou visualizá-las, como propõe o investigador britânico Martin Barker (2006), na sua teorização dos resultados do estudo internacional sobre $O$ Senhor dos Anéis, realizado em 2003-2004. Esse estudo, que precede o atual projeto em torno da obra $O \mathrm{Hob}$ bit, teve na sua base um inquérito disponível em 14 línguas e foi respondido por perto de 25 mil espetadores dessa trilogia.

A partir das conclusões alcançadas com esse estudo internacional, Martin Barker cunha uma nova dimensão no conceito de adaptação que, até então, tinha vindo a centrar-se na discussão em torno da fidelidade. Essa nova dimensão propõe-se, agora, travejar no conceito de visualização, enquanto o tornar visível aquilo que, segundo o que era proposto pela poética literária, não teria correspondente real. A figuração da poética cinematográfica permite uma visualização coletiva que, obviamente, pode ser convergente ou divergente com a poética literária quando se consideram segmentos diversos da audiência.

Até um passado recente, os Estudos Fílmicos tenderam a equacionar a questão da adaptação a partir do ponto de vista da fidelidade. Contudo, nos últimos vinte anos, esta abordagem tem vindo a ser questionada, desde logo por Robert Stam (2005). O autor interroga o que se pode entender por fidelidade, levantando a questão do significado ideológico de uma adaptação a par com a questão da eficácia da intertextualidade que está, irremediavelmente, comprometida com o conhecimento dos requisitos das audiências a que se dirige cada adaptação. No próprio projeto em torno da adaptação de $O$ Senhor dos Anéis, Barker já questionava a transposição da poética literária de Tolkien para a poética cinematográfica de Jackson. O investigador travejava a análise na rejeição do pressuposto de que o discurso interior individual supera o nível de percepção e participação social semiótica (Esrock, 1994).

Barker contou quer com as perto de 25 mil respostas aos questionários quer com 300 entrevistas realizadas no âmbito do projeto sobre $O$ Senhor dos Anéis, para este conceito de visualização. Assim, pela interpretação dos questionários que reportavam à transposição da poética literária de Tolkien, no caso específico de $O$ Senhor dos Anéis, para a poética cinematográfica de Jackson, o investigador britânico foi levado a concluir que os Estudos Fílmicos que incidem sobre de adaptação devem incorporar um novo conceito, a visualização. Esta é concebida como gestalt de significados e emoções e já 
não enquanto mera encenação pictórica, que entrevistados revelam quando se referem ao invocar a satisfação (ou não) de ver a representação imagética do que, até então, só podia ter sido representação imaginária, e portanto, subjetiva.

Desta forma, a visualização vai no sentido de uma imaginação partilhada que, inevitavelmente, se traduz num sentimento de pertença e, paradoxalmente, na consciência da identidade individual, de cada vez que o eu reconhece que o outro comungou (ou não) a representação da poética literária. Ou seja, o conceito de visualização a que Barker chegou a partir desse projeto mundial propõe um novo nível de relacionamento entre a poética literária e a poética cinematográfica. Ao invés de convocar a questão da fidelidade ou da identificação através do reconhecimento da partilha do imagético, a visualização dá lugar a uma superação da história. Através da visualização, é possível transpor o imaginário para o lugar do imagético, dando lugar a um significado mais amplo. Barker conclui que este conceito de visualização contribuiu para transformar o modo tradicional de encarar os Estudos Fílmicos sobre Adaptação (2006: 22) como lugar de discussão da transposição do imaginário para o imagético.

\section{Tolkien e o cinema digital}

Desde os seus primórdios que o cinema convoca o imaginário do espectador por via do olhar. Às imagens mais ou menos documentais dos irmãos Lumière, Méliès fez suceder um novo uso da nova tecnologia propondo-se contar histórias como forma de ultrapassar o impasse a que as saídas das fábricas, os comboios a chegarem às gares e os bebés a serem alimentados tinham conduzido o ambiente cinematográfico. Aos sucessivos retratos do quotidiano, Méliès contrapropôs o mise en scéne. Trabalhando a partir de um estúdio, criou os primeiros efeitos especiais do cinema que lhe permitiram convocar a imaginação e ousar para lá do real (Sadoul, 1983: 61).

Foi a partir desta concepção de cinema como lugar e tempo do imaginário que somos chegados à utilização dos novos avanços tecnológicos que imperam no cinema digital e no trabalho de pós-produção. Ou seja, o cinema ganhou definitivamente a sua proposta de contador de histórias, numa sala emersa na escuridão, projetando imagens num grande ecrã, assim reproduzindo o estado onírico mesmo que, como disse Christian Metz (1980: 112), o espectador seja 
um sujeito acordado e o sonhador um homem adormecido. $\mathrm{O}$ espetador sabe que o que vê não é real, é pelo denominado efeito de real que o espectador aceita o pacto narrativo, cria um significado (o que está a ver) e um significante (o que imagina).

As novas tecnologias digitais proporcionam-nos novas imagens e, neste sentido, são o espaço de criação de novos imaginários. Hoje, na era das tecnologias digitais, o cinema ficcional continua a desempenhar a sua função de representação do que não tem equivalente real, continua a ser uma construção imagética e imaginária (Aumont, 2008: 95) ainda que, como defende Christofolli, o cinema digital contribua em especial para esse efeito de sonho de cada vez que nos apresenta e confronta com objetos irreais. Mas se a câmara real nos apresentava narrativas que não eram reais, a questão será, então, a de sabermos o que esperar de uma câmara que não é real.

O cinema de hoje é, tantas vezes, um cinema sem câmara, um cinema de imagens em flash ou em Dreamweaver, criações em 2D ou 3D que não sofreram truncagens ou que foram iludidas num décor sem teto ou profundidade. São imagens idealizadas e desenhadas pela mão humana com o auxílio da computação - nunca viram a luz do dia, nunca saíram de trás de um ecrã. Então cabe perguntar: A fantasia a que a tecnologia cinematográfica de hoje acede poderá interferir nas narrativas cinematográficas? Estar-se-á, hoje, tecnologicamente mais apto a representar o fantástico, conferindo-lhe verosimilhança? Estará, hoje em dia, a tecnologia apta a trazer para a poética cinematográfica o que antes estava, aparentemente, confinado à poética literária? Poderá a tecnologia digital criar novas narrativas, com novos sujeitos que, sendo irreais, ganham realidade por via da tecnologia? Estaremos a assistir a uma nova era no relacionamento entre a literatura e o cinema? A questão está longe de ser consensual.

Não se afastando da proposta tolkieana, em 1969, longe da diversidade de contextos de visionamento do cinema nos dias de hoje, Gollin defendia: "Embora partilhem certos elementos dramáticos, geralmente enfatizadas pelo filme, romances e filmes exigem sensibilidades completamente diferentes. Os romances são lidos por indivíduos concentrados na leitura, lendo ao seu próprio ritmo e capacidade de concentração imaginativa, governados por vozes narrativas ouvidas e escutadas. Um filme é, por outro lado, realizado para o seu público numa sala na semiobscuridade na qual a consciência pública e privada se fundem numa única experiência visual e auditiva intensamente 
compartilhada, movendo os espectadores de acordo com seus próprios ritmos" (Gollin, 1969: 424-425) ${ }^{8}$.

Nos finais da década de 30, no ensaio On Fairy-Stories, Tolkien não referenciou o cinema, ainda que este já se construísse como contador de histórias e produtor de mundos imaginários e imagéticos, até mesmo com aproximações ao fantástico, como seria o caso do expressionismo alemão da década de 1920. Tolkien deixa de fora desta reflexão as artes não miméticas (música e arquitetura), e consagra o seu ponto polémico no que diz respeito à poética e à sua relação com o teatro pautando-se pela proposta aristotélica, em A Poética, que defende que à epopeia cabe o irracional, fonte do maravilhoso, enquanto que na tragédia, o maravilhoso resultaria em cómico.

Com Aristóteles, Tolkien reserva para a poética o maravilhoso que considera, também ele, não se coadunar com a representação em palco - que, à semelhança das imagens cinematográficas, se afasta do mundo interior e onírico da leitura e se aproxima, pela visibilidade conferida pela representação, do mundo primário. Assim, para Tolkien, o teatro (a representação imagética) distingue-se da literatura: o primeiro é o lugar do humano, a segunda é o lugar mais amplo dos contos de fadas, o lugar fantástico, no qual é possível o efeito estético do encantamento (Tolkien, 2011: 60). Lendo a contragosto a sinopse apresentada por Forest Ackerman com vista a adaptação para cinema da obra $O$ Senhor dos Anéis, Tolkien reagiu negativamente à proposta de adaptação, como vimos.

Décadas mais tarde, é a mesma Hollywood que tende a ver no best-seller o blockbuster. A tecnologia digital permitiu a Peter Jackson (re)construir e representar o imaginário fantasioso de Tolkien. Legiões de fãs acorreram aos cinemas. De resto, o escritor havia já renascido por via dos jogos de computador que se inspiravam no seu imaginário. Mas a pergunta permanece: pertence à construção reflexiva de Tolkien a possibilidade de adaptação da sua poética literária a poética cinematográfica?

8. No original: “(...). Though they share certain dramatic elements, usually emphasized by the film, novels and films require altogether different sensibilities. Novels are read by private individuals sunk deep into themselves, responding towards according to their own pace and capacities for imaginative concentration, governed by narrative voices heard and overheard. A film is on the other hand performed on its audiences in a dark place where private and public consciousness merge into a single intensively shared visual and auditory experience, moving its viewers according to its own rhythms" (Gollin, 1969: 424-425). 
Tomando em consideração o acima exposto, e alavancando a reflexão no ensaio, On Fairy-Stories, e no conto Leaf by Niggel, do mesmo autor, então, somos levados a concluir da não legitimidade desta tradução. A representação imagética do texto convoca o espectador no lugar do leitor. Assim, à interioridade da leitura, propõe-se a semiobscuridade da sala de cinema, ou a claridade no download num computador. O mundo imaginado ganha forma, e surge-nos ao olhar. A não tradutibilidade é confirmada no conto Leaf by Niggel.

\section{E no entanto, $O$ Hobbit foi feito filme...}

Nos Estudos de Cinema, a própria teoria da adaptação reconhece que o modo de contar e o modo como o destinatário é convocado, são diferentes quando nos reportamos a um texto literário ou a um texto cinematográfico. A nossa cumplicidade com o texto começa, desde logo, na nossa imaginação e, por isso, aceita-se que as palavras povoam a imaginação de forma mais consistente e prolífica quando comparadas com uma imagem. A imagem mostra-se, não se faz dependente da nossa imaginação: está lá! O pacto narrativo não desaparece. Num certo sentido, mantém-se porque ao espectador continua o pedido que "acredite que é verdade". Também é verdade que a tradução para texto cinematográfico não se quer fiel - nem poderia sê-lo posto que estão a ser considerados meios diferentes (livro e ecrã). Considerando o cinema comercial, convém não descurar que a escolha dos atores e a construção das personagens obedecem a critérios que os tornam comercialmente proveitosos.

No presente caso de $O$ Hobbit, a questão que poderemos ver respondida é se o conceito de visualização a que Martin Barker chegou se mantém: se em O Senhor dos Anéis, a poética cinematográfica propunha uma estrutura narrativa próxima à da poética literária originária, cuja exceção mais marcante é a subtração do núcleo dramático da personagem Tom Bombadil, no presente projeto, The Hobbit, somos confrontados com alterações de plot profundas, introdução de novas personagens e alterações narrativas. A análise dos resultados dos questionários será relevante para clarificar esta nova proposta de transposição já que a poética cinematográfica não segue tão de perto a poética literária original e originária, como sucedeu com a transposição de $O$ Senhor dos Anéis.

Seja no livro, seja no ecrã, a verdade é que lendo ou assistindo, a personagem de Bilbo Baggins nos provoca respostas emocionais. Assim, tanto no 
livro como na sua adaptação cinematográfica assinada por Peter Jackson, $O$ Hobbit apresenta-se em conformidade com o pacto narrativo, ou seja, acreditamos que existe aquele pequeno ser que viveu aquela aventura em tudo tão semelhante à Alegoria da Caverna de Platão: um homem encarcerado, aventura-se e abandona a sua morada, e com isto descobre a verdadeira realidade; também Bilbo vivia numa toca debaixo do chão, levava uma vida tranquila numa comunidade que prezava as convenções, um dia, ele arriscouse a abandonar a tranquilidade da sua morada e aventurou-se numa demanda que lhe permitiu descobrir a sua verdadeira natureza, experimentar um mundo novo e regressar, ainda que passe a ser visto como diferente pelos seus iguais.

Seja no livro, seja no ecrã, seja em conformidade com os desejos de Tolkien, seja em conformidade com as crenças de Peter Jackson, a verdade é que Bilbo ressurgiu e que $O$ Hobbit surge, mais uma vez, quando o mundo dos seus leitores e dos seus espectadores se fragmenta em novos paradigmas, se não agora para a modernidade, já para a hiper-modernidade.

Pouco mais de uma década depois da pesquisa mundial a $O$ Senhor dos Anéis, Martim Barker, juntamente com Matt Hills (Reino Unido) e Ernest Mathijs (Canadá), dirige um novo estudo mundial sobre esta trilogia novamente adaptada e dirigida por Peter Jackson. The World Hobbit Projet reúne agora investigadores de 47 países de todos os continentes, entre os quais Portugal e Brasil. O inquérito dirigido aos espectadores desta trilogia, construído em inglês foi traduzido para 36 línguas. Desde o seu lançamento, em Dezembro de 2014, até meados de Abril de 2015, no momento em que escrevemos estas linhas, tinha sido respondido por mais de 34 mil espectadores, de 157 nacionalidades. ${ }^{9}$

A análise destas respostas, a nível internacional e a nível de cada país, permitirá identificar de que modos é vista esta relação entre a literatura e o cinema por parte dos espectadores de todo o mundo que responderam ao inquérito internacional. Entre as mais de 34 mil respostas que serão analisadas nos próximos meses, perto de mil vieram de espectadores portugueses. De que modos fatores como a sua geração, género, educação, conhecimento prévio ou não da obra literária ou significado do conceito fantasia, entre outros, afetam a sua relação com a adaptação cinematográfica? De que modos

9. Mais informação sobre o projeto e o questionário em www.worldhobbitproject.org 
as condições do fazer cinema digital são experimentadas e expressas por estes espectadores?

\section{Bibliografia}

Aristóteles (1951). Poética. Trad Prof. Eudoro de Souza. Lisboa: Guimarães EditoresImprensa Nacional-Casa da Moeda.

Attebery, B. (1992). Strategies of fantasy. Indiana UP: Bloomington.

Aumont, XX (2008). A Imagem. Edições Texto e Grafia: Lisboa.

Barker, M. (2006). Envisaging 'Visualisation': some challenges from the international Lord of the Rings audience project. Film-Philosophy, The University of Wales, Aberystwyth, 10(3): 1-25, December, www.filmphilosophy.com

Betttelhiem, B. (2002). Psicanálise dos contos de fadas. Trad. Carlos Humberto da Silva. Lisboa: Bertrand Editora.

Brooke-Rose, C. (1983). A rethoric of the unreal: studies in narrative and structure, especially of the Fantastic. Cambridge, London, New York, New Rochelle, Melbourne, Sydney. Cambridge University Press.

Christofolli, E.P. (2010). O Cinema digital como construtor de novos imaginários. Revista rumores, edição 7, 1, janeiro-junho.

Esrock, E.J. (1994). The reader's eye: visual imaging as reader response. Baltimore: Johns Hopkins University Press.

Gollin, M.R. (1969). Film as dramatic literature. College English, 30(6): 424429, Mar. Published by National Council of Teachers of Englisg, acessed 14/1/2011 www.jstor.org

Jackson, R. (2007). Fantasy: the literature of subversion. London, New York: Routledge.

Reis, A. \& Lopes, A.C.M. (2011). Dicionário de Narratologia. Lisboa: Ed. Almedia.

Sadoul, G. (1983) História do Cinema Mundial, I. trad. Manuel Ruas. Lisboa: ed. Livros Horizonte.

Stam, R. \& Raengo, A. (eds.) (2005). Literature through Film: a Guide to the Theory and Practice of Film Adaptation. Oxford: Basil Blackwell. 
Todorov, T. (1975). The Fantastic - a structural approach to a literary genre. Sage House: New York.

Tolkien, J.R. (2007). O Hobbit. Trad. Fernanda Pinto Rodrigues. Lisboa: Edições Europa América.

Tolkien, J.R. (2013). The Hobbit. London: Harper Collins Publishers.

Tolkien, J.R. (2011). Tree and Leaf. London: Harper Collins Publishers.

Vieira, L. (2013). O senhor dos Anéis na literatura e no cinema: Diálogos de artes e imagens, IV encontro nacional de Estudos da Imagem - I Encontro Internacional de Estudos da Imagem 07 a 10 de maio. actas: 1724 -1731. Universidade estadual de Maringá.

Propp, V. (1978). Morfologia do conto. Trad portuguesa Jaime Ferreira e Vitor Oliveira. Lisboa: Editorial Vega.

Woolf, V. (2008). The Cinema in Selected Essays. Oxford: ed. Oxford University Press.

\section{Webgrafia}

www.tolkienlibrary.com (acedido a 14/12/2014)

www.oed.com (acedido a 14/12/2014)

www.gutenberg.org (acedido em 12712/2014)

www.worldhobbitproject.org 
$\bigoplus$

$\bigoplus$

$\oplus$ 


\title{
Journalism and Mass Communication Training in Nigeria: Some Critical Thoughts
}

\author{
Olusegun W. Ojomo \\ Babcock University \\ E-mail: ojomoleyahoo.co.uk
}

\begin{abstract}
A major feature of any progress-prone human setting is the capacity to reflect on its acts. Reflection entails retrospectively evaluating one's actions with the intent to encourage what works and halt what does not. This paper reflects on vital issues in journalism and mass communication training in Nigeria by highlighting and discussing these issues from the standpoints of where we are and where we could be. Using the Reflective Practice theory as a framework, the author examines issues around such variables as admission

processes, quality of faculty, curricula, programme accreditation, internship and training infrastructure. The paper identifies the absence of synergy between journalism academia and the industry as a major gap in the total process of journalism education in Nigeria. The paper is strewn with relevant recommendations that could bring the Nigerian journalism and Mass communication training to the front row and thus enable it to compete effectively with journalism training institutions in advanced climes.
\end{abstract}

\section{Introduction}

$\mathrm{N}$ almost every profession, the production of trained quality staff is closely linked to the availability of appropriate institutions to train such staff. Unlike several other professions in Nigeria, journalism has been in practice long before there were training institutions to produce journalists. For instance, the first newspaper in Nigeria, Iwe Irohin was published in 1859, but formal training of journalists did not begin until 1954 when a two-week vocation course was conducted at the University College, Ibadan, (Adaba, 1989).

Radio had existed since 1932 as a virile medium for the dissemination of information by the colonial government, but formal training for radio journalists did not start until 1956 when a two-year in-service training was floated by 
the news department of the then Nigerian Broadcasting Corporation, (NBC). The same can be said of television which started in 1959, but the Television College, Jos was established only many years after, in 1980.

In comparison with Europe and America, journalism is a young profession in Africa, but its phenomenal growth has created an increasing demand for trained journalists. Early practitioners in Nigeria had no formal training; they only had basic education, and interest in journalism practice. Added to these was their awareness of the power of the pen and the realization of its potency in the fight against colonialism. In the 1900s, Ernest Sesei Ikoli left his job as a teacher at King's College, Lagos to join the Lagos Weekly Record. He was trained on the job by John Payne Jackson, the publisher of the newspaper. Several others equally got in-house tutoring. For example Obafemi Awolowo was trained at the Daily Times in the 1930s. Others who could not be trained in-house simply learnt by doing. For instance, after studying in the United States, and with exposure to various statutes on national self-determinism, Nnamdi Azikiwe established and edited the West African Pilot in 1937. He thereafter established six other newspapers which were strategically located in important cities in Nigeria (Uche, 1989). The first university mode training for journalists was the Jackson College of Journalism (now department of Mass communication, University of Nigeria, Nsukka), named after John Payne Jackson, the publisher of Lagos Weekly Record. The College started off with forty seven students and four full time staff in 1960.

The successful pioneering of university mode training of journalists in Nigeria by University of Nigeria Nsukka was followed by the University of Lagos which floated a one-year practical diploma for working journalists in 1967. Candidates for this programme were required to be sponsored by an established media organisation.

Between 1967 and 1980, only these two institutions offered university training in journalism. As at 2000, there were 58 journalism training institutions in Nigeria (Akinfeleye, 2000). These institutions provide manpower for over 78 press titles, over 68 magazine titles, 138 radio stations and 140 television stations, (mediafacts, 2010).

Various interested parties have expressed concern on the need for quality in journalism education. This concern is informed by the strategic roles of journalists in society and governance. As the fourth estate of the realm, journalists are the harbingers of the ideals of the structures and institutions of 
democracy. They keep the society and its various parts running through the provision of information needed to make policy decisions. The position of the journalist in society is similar to that of a physician. Without good training and strict professionalism, the client's life is in danger of wrong diagnosis and therapy. An ill-educated journalist could be a problem than an asset to society. As early as 1964, Nnamdi Azikiwe had noted:

...in order to live up to its highest standards and ethics, there is need in this country for journalists who will take pride in their profession and develop a sense of duty to the public.... An ill-educated journalist is a liability to the press and to the nation, but a professionally-trained journalist, who is armed with a background of sound university education... will transform the practice of journalism into an asset to the credit of our nation. (p.8).

As regards training and practice, the Nigerian mass media have their orientations after the British and American systems, and with globalization, there have been influences from other parts of the world. These influences also come with the responsibility to provide the appropriate settings needed to make Nigerian journalists compete effectively with their counterparts in other climes. The casual observer of Nigeria's journalism and mass communication training would concede to the existence of certain challenges requiring critical thoughts and reflection. This is the focus of this paper.

\section{Reflective Practice}

This focus of this paper is theoretically situated in the reflective practice theory. Literature on journalism education and practice reveals pressure to develop more critical educators and practitioners and to address rapid technological change. It also addresses the need for a balance in theory and practice towards ensuring improved performance of journalists and the journalism industry. Literature search on journalism education shows a profound dependence by scholars on reflective practice as a key concept around which theoretical framework on the subject is built. This section therefore examines this concept and its place in journalism education and practice. 


\section{Defining Reflective Practice}

A few authors have defined reflective practice. Thompson (2002) states that "reflective practice is an active process of constructing solutions, rather than a passive process of following procedures or guidelines." (p.235). Schön (1996), in Ferraro, (2000) defined it as "thoughtfully considering one's own experience in applying knowledge to practice while being coached by professionals in the discipline." In the view of Bolton (2007), "reflective practice is a process of learning and developing through examining our own practice, opening our practice to scrutiny by others and studying texts from the wider sphere." (p.4).

From the standpoint of education, reflective practice is the process of the educator studying his or her own teaching methods and determining what works best for the students. From the angle of the practitioner, Ferguson (2011) speaks of the necessity for practitioners in any environment to consider how best to refresh their practice, to get better at what they do, to benefit from good practice that they may have seen in others or to avoid aspects of their own practice that students or others have told them need correction.

Thompson (2002) states that "a reflective practitioner ...is a worker who is able to use experience, knowledge and theoretical perspectives to guide and inform practice...reflective practice involves cutting the cloth to suit the specific circumstances, rather than looking for ready-made solutions." (p.235). Another useful definition was offered by Kev Judge who said:

A 'reflective practitioner' is someone who, at regular intervals, looks back at the work they do, and the work process, and considers how they can improve. They 'reflect' on the work they have done. They are not happy to carry on at the current standard, they want to improve, they do not believe in the saying, 'if it ain't broke don't fix it'. Everyone should be a 'reflective practitioner', You need to learn from the experiences, and mistakes of others, you need to look at what you are doing and how others are doing the same thing; can anything be improved? Can anything be done better?

www.sharpy.dircon.co.uk viewed on the $23^{\text {rd }}$ June, 2011.

Reflective practice is common to and practiced by all professions, thus the medical glossary defines it as "the process of improving professional skills by 
monitoring your own actions while they are being carried out, and by then later evaluating them by talking or writing about them and asking other professionals to give their assessments of you." http://www.medical-glossary.com viewed on the 23rd June, 2011.

In other words, the reflective practitioner is flexible in his approach to practice. He relies on the gains obtained through experience in previous jobs to improve on the next task by looking into what went wrong and what worked right with the aim to achieve better performance. At the core of reflection is the thought "if you always do what you always did, then you will always get what you always got." Thus, the reflective practitioner asks "How can I improve my practice?"

The place of reflective practice becomes important to journalism practice when we appreciate the link of theory and practice in journalism. Theory is the basis of practice and practice is the explanation of theory. The interrelationship between both makes it important for journalism teachers and practitioners to work together towards enabling journalism graduates appreciate and imbibe both ends.

Burns (1997), cited in Burns (2004), stresses this point by noting that:

Critical self-reflection is the cognitive bridge between journalism theory and professional practice. It is through critical self- reflection that journalists develop self-reliance, confidence, problem solving, cooperation and adaptability, while simultaneously gaining knowledge. Perhaps more importantly, it develops in students a sense of professional efficiency in their ability to negotiate the dilemmas and complexities that are inherent in their practice. Reflection is also the process by which journalists learn to recognize their own assumptions and understand their place in the wider social context. (p.6).

For the student journalist, reflective practice skills make the student vacate the conventional position of the passive receiver of a body of knowledge that the teacher selects, to an active processor of useful and applicable knowledge. Thus, the student distils and absorbs that knowledge that is useful for problemsolving both on training and professional tasks. Indeed, it is the on-the-job process of problem-solving that characterizes the practitioners. This way, the students are able to engage in the active role of solving the problems that confront them with situations that reflect the real world. Engaging students 
in problem-solving at training prepares them to do it more easily on the job. Burns (2004) speak thus "By emphasizing the process used to complete a task or make a professional decision, students are encouraged to learn in a selfdirected way. The thinking skills required by the graduate practitioner are identical, prescribed, practiced and evaluated." (p.7).

Journalism educators must value the opportunities provided by institutional environments to expose students to learning by doing as knowledge and skills obtained through such means provide good foundation for better productive working life. It is pedagogically risky not to allow students to engage in such activities as internship, campus newspapering, reporting and editing, campus radio and television activities. These opportunities provide students with experiential learning settings similar to those they would have in a real life work place.

Historically, the term reflective practice was introduced by Donald Schön in his 1983 book The Reflective Practitioner. However, the foundational concepts of reflective practice have been around since the days of John Dewey who first wrote about reflective practice with his investigation of experience, interaction and practice. According to Dewey, (1933), cited at www.ehlt. flinders.edu.au, we begin to reflect on a complex situation when we face that situation and ask ourselves what needs to be done. Dewey had described the difference between impulsive action, routine action and reflective action. In his view, impulsive action is based on trial and error, routine action rely on conventional ways of doing things, sanctioned by authority. These two methods, he felt were used by practitioners without engaging in much thought about how they were operating. Reflective action, Dewey claimed arose from the works of educators who were active and proactive, who persistently and carefully considered how they practiced and what they were teaching and was often the result of a need to solve a particular problem.

Reflection can be informal or formal. Informal reflection involves selfquestioning and develops our awareness of our own assumptions. It is also the basis of other forms of reflection. Formal reflection on the other hand draws on research and theory and equally provides guidance and framework for practice. Whereas informal reflection may be done sometimes unconsciously, formal reflection is deliberate and goal-oriented. It is equally task-based because it aims at resolving a critical issue. 
David Schön (1987), cited in Allen and Miller (1997) suggests a strategy for placing what he called "reflective practicum" at the centre of the work of professional schools as a way of creating a bridge between the world of practice and the world of academy. This way, in his view, it is possible to move towards resolving some of the conflicts between the academic and vocational dimensions of the professional schools. Schön believes you can reflect-inpractice or on-practice. Reflection-in-practice occurs when you reflect right and when you are engaged in the activity. This involves you thinking on your feet and responding immediately to a situation. Reflection-on-practice is when you reflect afterwards. It involves thinking about your experience and drawing learning from it for improved results. According to Schön, "when someone reflects-in-action, he becomes a researcher in practice context. He is not dependent on the categories of established theory and technique, but constructs a new theory of the unique case." (p.59). Schön's point here is that the process of reflecting-in-practice creates an awareness of better ways to accomplish a unique task rather than following known ways, especially if the known ways have not provided useful solutions.

Ortiz (2006) describes both types of reflections thus; "Reflection-in-action is a heightened awareness of what one is doing at the time of activity. Consider for example, a neurosurgeon thoroughly maneuvering a surgical saw during cranial reconstruction, highly mindful about the action and analyzing results in order to make necessary adaptations during the procedure. By contrast, reflection-on-action is the reflection you do after the event: thinking through, and often discussing the incident with a colleague or supervisor. In this post hoc reflection, the learner understands complex experiences, applies theory to them and is able to solve problems and improve practice.

Being able to critically reflect is one of the most valuable skills that one can develop and it is the key to successful work-based learning. It also enables one to use whole of life experiences as the basis for learning. Important to journalism education is the need for formal reflection by stakeholders on better ways to achieve the goals and missions of the field. This is the emphasis of the $8^{\text {th }}$ declaration of the World Journalism Education Congress (WJEC) in 2007 which reads thus: "Journalism educators should maintain strong links to media industries. They should critically reflect on industry practices and offer advice to industry based on this reflection." Though it can be admitted that stakeholders have engaged in formal reflection through conferences and 
annual meetings at which critical issues about journalism and mass communication education have been reflected upon, the gains of such meetings have been minimal and have at best only scratched the surface of the problem. To optimize the gains of reflection therefore, there is the need to go beyond formal reflection to reflection on action, a process that allows various parties to journalism education and practice to address the issues dispassionately.

\section{Doubts about Reflective Practice}

In spite of its wide acceptance among educators and practitioners, reflective practice has been criticized as not being potent enough to solve all the problems of theory-practice relationship in journalism education. One major criticism is that reflective practice is too individualistic in its conception of learning and that it leaves out the social dimension of learning. The argument is that people do not only learn through the process of introspection as enunciated by reflective practice, but genuinely through conversation and interaction with other people.

Greenberg (2007) points out another deficiency of the theory. This she said is the absence of a two-way feed-back mechanism. According to her,

Cultural studies born into a world of single disciplines, was seen as radical at birth because of its multidisciplinary nature. However, in its effort to win academic respectability, it has been traditional in giving more kudos to high theory and assuming a one-way flow of ideas from theory to practice. One gets the impression that it is the practitioners who are doing all the work in this marriage: here has been a good deal of effort to show how theory can transform the teaching of practice, but not so much that asks how practice and the perspective of practitioners might influence theory. (p.295).

Again, it has been discovered that such contexts as institutional and interpersonal curricula play a vital role in reflection. Without these supportive contexts, it is difficult to fully harness the potentials of reflective practice.

\section{The purposes and prospects of journalism education}

The media are an integral part of the society. They have been so integrated into the society that without them the society is almost lifeless. They play 
vital roles in the development of the society as enunciated in the postulates of the development media theory. It must be noted however that the media are mere tools in the hands of their human operators. In essence, the performance of the media in society is directly related to the performance of the individuals behind them in terms of their quality, competence and credibility. By extension, the quality of the individuals is equally related to the quality of the educational system that produces them. Thus, there is a domino effect in the total system such that one affects the other. If the quality of the journalists depends on the quality of the educational programme that produces them, then the programme should be implicated each time the journalists perform below standards. Almost every institutional set up has been known to have one form of mission statement or the other whether implicit or explicit. Mission statements give force and vigour to the vision of an institution. They give faculty and students something to run with and in what direction to run. Without purposes and mission, journalism education is at the risk of extinction.

In 1994, the Association for Education in Journalism and Mass Communication (AEJMC) and the Association of Schools of Journalism and Mass Communication set up a joint committee to review the missions and purposes of journalism and mass communication education. Part of the committee's mandate was to "examine the actual and appropriate missions and purposes of journalism and mass communication education, as well as the specific activities which programmes undertake to implement their missions and accomplish their goals." (Christ \& Hynes, 1997, p.1). According to these authors, "creation of the committee was a response to several developments, including specific difficulties experienced by some departments in persuading university administrators of the centrality of journalism and mass communication programmes to their universities and the consolidation of various programmes titled "communication" as some universities response to the economic recession of the early 1990s." (ibid.).

Rather than looking at the goals and missions of journalism education of individual institutions, this session takes a look at the omnibus goals and missions of journalism and mass communication education. That is, examining the purposes and missions of JMC from a general perspective. It is from the general goals and missions that specific departments can distil their individual goals and missions. 
According to the AEJMC Task force 2000, "The goal of journalism and mass communication program is to provide students and the larger society with a deeper understanding of mass communication processes and to improve the practices and performance of mass media professionals." (ibid., p.2). This goal suggests that the larger society is vital to journalism and mass communication education. It also aims to improve the knowledge of students on its programmes as well as support media professionals to achieve better delivery of communicated messages. The Association for Education in Journalism and Mass Communication Task Force on curriculum noted that:

...the purpose of media education is to produce well-rounded graduates who have critical thinking skills as well as practical skills, and who have an understanding of the philosophy of the media and a dedication to the public service role that the media have in our society. (ibid., p.2).

Again, the society and the students come up as vital concerns in journalism and mass communication education, thus suggesting that they deserve adequate consideration in the mission and goals of any journalism and mass communication programme.

The way it works is that the society is the ultimate beneficiary of a wellpackaged journalism programme because the society encapsulates everyone including the managers of the programmes as well as the products of the programme i.e. the students. The focus however begins on the students who must be groomed to deliver professionally acceptable practice to society, because it is only when they do this that the safety of every element in society can be guaranteed. Critical thinking skills are vital in journalism education in order to build journalists who can adequately educate the public through incisive analysis and discussion of issues in the public domain. This is one of the key yardsticks that can be used for assessing the training quality and performance of the journalist. Writing on Reflective Practice in Journalism Education, Allen \& Nod (1997) observed that: "In response to pressures on journalism education to develop more critical practitioners and to address rapid technological change, explicit structured reflection can be harnessed to address learners' ability to think critically about their professional practice and to deal with issues of technology in a clear and uncluttered manner." (p.1). The concession to the need for critical thinking and practical skills in journalism training can be attributed to journalism trainers" and practitioners' "re- 
flection" on the importance of reflective practice as a vital theory in the field. Indeed, Greenberg, (2007) supports a total replacement of former approaches to programme assessment with reflective practice arguing that "in some cases, practice is offered as an alternative to the old split -instead of assessing how programmes balance theory and practice we are advised to judge how well they teach critical self-reflection." (p.295).

This perhaps coincides with the thoughts of Vartan Gregorian of the Carnegie Corporation in a 1998 New York Times article when he said that "journalists should be the sense makers of the society and educated accordingly" (Cohen, 2001). This emphasizes the close link between a well-educated journalist and the overall wellbeing of the society. This link must however be embedded in the vision and mission of the mass communication and journalism programmes in order for it to be sustained and grounded. According to Galvin (1992), cited in Christ and Hynes (1997), developing goals and mission statements can produce at least four benefits which include:

1. Clarifying organizational purpose

2. Forcing consensus on what is important

3. Creating a framework against which to evaluate resource allocation

4. Reinforcing a commitment to student learning.

Important as all these points are, number two stands out for our attention here. All players in journalism and mass communication education in Nigeria must agree on what is important to journalism and mass communication training programmes. One way to do this is through a clearly defined mission and purpose from which local departments, faculties and students can derive inspiration and direction.

\section{Concerns for critical thought}

\section{Accreditation}

The basic logic of the accreditation process is to determine whether an institution possesses the capacity to run a journalism and mass communication programme. An honest assessment of the exercise shows it has become an arrangement of "I rub your back, you rub my back"amongst the various departments and the accreditation teams. Very often, there are instances of 
institutions using mercenaries as staff or renting equipment for the period of the exercise. These attitudes weaken the capacity of the institutions to honestly deliver their mandates to their students. One suggestion to upgrade the accreditation process might be to include practitioners on the visiting teams. This is expected to create some level of neutrality and balance as well as provide better hindsight to the exercise.

\section{Admission}

The quality of enrollees in any academic programme is a strong determinant of the quality of the graduates on such a programme. Two issues are critical to the admission processes in journalism and mass communication training in Nigeria, namely: the quality of admitted students in terms of their orientation and readiness to pursue careers in the media or media-related world. Clearly, this is beyond the various schools and departments since the admission process is done by the Joint Admissions and Matriculations Board (JAMB). However, where a policy shift liberalizes the process, institutions should consider interview-based screenings that enable them admit careerfocused candidates with genuine interests in the field of journalism and mass communication. This in itself has its inherent challenges one of which is that "man-know-man", a Nigerian factor could play up thus creating a worse problem.

A second critical point is number. With a practical-oriented course as journalism and mass communication, it is difficult to comprehend how institutions enroll as much as between a hundred and two hundred students in a year. This is more common in some private universities which pursue budgetdriven admissions exercises with very little thoughts for their implications on the students and the entire process. Often, faculties of such institutions are not trained in teaching large classes.

\section{Quality of Faculty}

One of the major points of criticism of journalism education globally is that schools and departments of journalism and mass communication seem to prefer holders of $\mathrm{PhD}$ degrees and researchers to experienced professionals on their faculty. This, clearly is a basic requirement by the National Universities 
Commission, (NUC), the regulatory body for universities in Nigeria. Like any other point of criticism of journalism education, the issue of $\mathrm{PhD}$ versus professional experience has existed for long and has generated much controversy. For instance, in a study cited by Applegate, David Boroff, in his article What Ails the Journalism Schools? argued that the PhD has the effect of freezing out some of the best journalism teachers. Interestingly, the argument to deemphasize research and $\mathrm{PhD}$ has come majorly from professionals and hardly from educators. Commenting on Tebbel's criticism, Applegate observes that "It must be remembered that a university's prestige is measured in one sense by the number of faculty with $\mathrm{PhD}$ degrees. Since a university's administration deems research as one of its missions, the quest for faculty with $\mathrm{PhDs}$ will not cease. On the contrary, the quest will grow stronger." (p. 95).

Clearly, those who support de-emphasizing PhD have a herculean task on their hands taking into consideration the great emphasis placed on $\mathrm{PhD}$ and research for appointment, promotion and accreditation by relevant parties to tertiary education. For instance, to attain the position of a senior lecturer in most Nigerian universities, a faculty must have a $\mathrm{PhD}$ degree. Also, to get appointed to any worthwhile position such as head of department or dean of a school or faculty requires a doctorate degree.

Again, the number of $\mathrm{PhD}$ holders vis-à-vis non- $\mathrm{PhD}$ holders that a department presents is taken seriously among other factors in determining whether or not a programme gets accredited. Emphasis on $\mathrm{PhD}$ is also premised on the assumption that faculties are supposed to be adept at research and the process of attaining a $\mathrm{PhD}$ degree is expected to groom the teacher in the art of research; and the degree itself ought to be a certification of sort. Thus, a university teacher without a $\mathrm{PhD}$ is assumed not to be a certified or chartered researcher.

It is not clear if anyone really doubts the ability of the professionals to do a good job of tutoring in journalism schools. The World Journalism Education Congress (WJEC) actually advises that they should as enunciated in its Declaration No 3 of 2007 thus: "Journalism educators should be a blend of academics and practitioners; it is important that educators have experience working as journalists." The snag it seems is putting the $\mathrm{PhD}$ issue in proper perspectives. This would entail the collaborative efforts of all stakeholders in determining the modalities for absorbing the professionals. There must be a means to assess their worth and experience and convert such into something 
equivalent to a $\mathrm{PhD}$. This mode is not entirely new as it is already a practice in City University in America, where, as reported by Greenberg (2007), a professional could earn a Doctorate in Journalism (DJourn) by submitting his past works and achievements for assessment. According to Greenberg, the programme "allows working journalists to submit their own practice as part of the assessment and contextualize it within a theoretical framework." (p.294). This format did not entirely begin at City University. Indeed, it was borrowed from the Columbia University Graduate School of Journalism led by communications scholar Dr. James Carey as a wider process of reflection about the appropriate role of a journalism and mass communication school in the $21^{\text {st }}$ century.

In juxtaposition with the Nigerian setting, the above perspectives may seem farfetched, however, they are instructive. The issues are: very often, industry practitioners with decades of experience retire and die with their experiences which could add immense value to the classroom if they are given the chance but with the $\mathrm{PhD}$ factor, they could be restrained either by policy or by intimidation. A panacea might be to adopt the City University in America approach noted above or evolve a creative, home-grown approach to the issue. A second issue is the fact that several faculty in our institutions do not possess industry experience needed to even out their theory background. A solution here might be to evolve policies that allow them to do advanced internships of one year or more in relevant organizations. Clearly, this requires synergy between the industry and the institutions. To make this attractive, such faculty must receive remuneration form both their employer and the interning organization for the period of the programme.

\section{Curricula}

Curriculum is central to any academic programme. It is the rudder which directs the ship of an academic endeavour. It also determines the competence that would be acquired by students, as well as the respect drawn by stakeholders in an academic programme. A great deal of debate has ensued among various interested parties to journalism education on what should be the complexion and content of the curriculum on journalism and mass communication education. As expected, there is no agreement yet on this and it is doubtful if there will ever be. A reason for this assertion lies in the nature of curricu- 
lum itself. A good curriculum must not aim only to prepare students for the challenges of the world of work, but must also reflect the social, cultural and political environments where it operates. Beyond this, it must affect the cognitive, affective and psychomotor domains of its recipients. Indeed, a good curriculum must be robust in its content while being specific in its goal. There are multifarious views on journalism and mass communication curricula today and this could be said to have their roots in the views of some of the pioneers of journalism education who had tremendous influence on the growth of the field.

\section{Training infrastructure}

The absence of appropriate and modern infrastructure has been the bane of the journalism and mass communication training in Nigeria. Taking into account the practical nature of the field, it is clear that without training facilities products of our institutions might end up as misfits in the work place. Very often, several trainees do not get opportunities to see, much less interact with basic equipment until their internships. This leads to the production of graduates with theory knowledge and near zero practical base. An important way out of this problem would be to make the accreditation process more credible by erecting effective checks and balances in the process. for instance beyond the extant ritualistic and ceremonious accreditation procedures, there should be random, impromptu inspection of facilities and faculty of training institutions with the policy to withdraw the accreditations of institutions which do not indeed possess such infrastructure and facilities as were presented during the accreditation exercise. Town-gown collaboration equally comes in here. Since the institutions are training for the industry, the industry could support the training programmes with funds and logistics for providing the needed infrastructure.

\section{Internships}

The fundamental motivation for internship in journalism and mass communication education is the creation of a platform for assessing the readiness of the trainee for the world of work. internship aims to help the student 
hone relevant skills on practical aspects of their training. According to Ojomo (2007),

a major purpose of internship is to provide a planned transition from the classroom to the job. Movement from the theoretical disposition of the classroom work to the practical work world without internship could a technical and social dissonance with damaging effects on graduates. Internship provides a smooth crossable bridge to the student without work experience. p.50.

A cursory observation by this author shows that the internship exercise has been reduced to a mere academic ritual observed not for its innate benefits but for the sake of it. in its present format, the exercise raises the following questions: How long should an internship last? What is the degree of coordination of the exercise by the department, that is how well are the students supervised by the faculty? Are the interns visited at their internship locations? Do the internships count for grades for the interns? Are the interns achieving the primary goals of the exercise or are they used merely as errand runners? What is the degree of cooperation between the interns' schools and the organizations providing the internships? Generally, the polytechnics seem to score higher than the universities on some of these points. For instance, several of the polytechnics do at least six months internships and in many cases eight or twelve months, whereas the universities do three months for most of the times. A ready recommendation here might be to make the universities run a five-year programme with a one year internship in the fourth year.

\section{Conclusion}

The mass media have come to be known as the fourth estate of the realm. This is in recognition of their role in keeping the government and the society generally focused on their relevant functions in society. The Nigerian media can be commended for their active roles in the periods before and after the nation's independence. However, it is clear that the media could play better and improved roles if the systemic challenges as identified here are address with the seriousness it deserves. For too long, players in the industry have allowed things to drift and this has led to blame-trading and unhealthy polemics. The issues identified are definitely not the only challenges of the industry and the 
training institutions neither are the recommendations proffered sure-fire solutions to the problems, but stakeholders in journalism and mass communication training and practice must continue to place the issues in the front burner in order to bring the field to the front row and make the industry take its proper place in national development.

\section{References}

Adaba, A.T. (1989). Harmonising training and research within national communication objectives, In Nnaemeka, Uvieghara and Uyo (Eds.). Philosophy and Dimensions of National Communication Policy, Vol. 1 ( $\mathrm{p}$. 235). Lagos: Centre for Black and African Arts and Civilization.

Akinfeleye, R.A. (2000). Proliferation of Journalism /Mass Communication Training Institutions in Nigeria and its Impact on Professional Standards in media and Democracy, A report of Workshop on Democracy and the Media (May21-23, 2000), Nigerian Press Council Centre for International Media Assistance. University Journalism Education: A Global Challenge, Washington.

Allen, R. and Miller, N. (1997). Reflective practice in journalism. Proceedings of the annual general meeting of the association for education in journalism and mass Communication. Chicago, Illinois, July 30-August 2.

Azikiwe, N, (1964). Pioneer heroes of the Nigerian press. An address delivered to the first graduating students of Jackson College of Journalism at a dinner in the Okpara hall on the $31^{\text {st }}$ of May, 1964 .

Bolton, G. (2001). Reflective practice: Writing and professional development. Paul Chapman Publishing: London.

Burns, G. (1987). The trouble with internships. Paper Presented at the Annual Meeting of the University Film and Video Association. Los Angeles, CA, August 6.

Christ, W.G. \& Hynes, T. (1997). The missions and purposes of journalism and mass communication education. Journalism and Mass Communication Educator, 52 (2): 74+.

Cohen, L. \& Manion, L. (2000). Research methods in education. Routledge: London. 
Ferguson, P.B. (2011). Becoming a reflective practitioner. www.waikato.ac.. Retrieved $15^{\text {th }}$, April, 2011.

Ferraro, J.M (2000). Reflective practice and professional development. Retrieved from ERIC database August, 2010. (ED449120).

Greenberg, S. (2007). Theory and practice in journalism education. Journal of Media Practice. 8 (3) Intellect Ltd.

Judge, K. (n.d). Retrieved www.sharpy.dircon.co.uk, on 22nd June, 2011.

Mediafacts. Retrieved on 24th February, 2015 at www.mediareachomd.com

Ojomo, O. (2007). Optimizing internships in mass communication training. Journal of Social Sciences and Humanities, Xv (1) Allama Iqbal Open University, Islamabad, Pakistan.

Ortiz, J. (2006). Reflective practice and student learning. In the Introductory Interpersonal Communication Course, www.mcli.dist, Viewed on $12^{\text {th }}$ March, 2011.

Schon, D. (2002). From technical rationality to reflection-in-action. In R. Harrison, F. Reeves, A. Hanson \& J. Clarke (eds). Supporting Lifelong learning, Vol. One, Perspectives on Learning, Routledge: London.

Thompson, N. (2002). People skills. Palgrave, Macmillan: Hampshire.

Uche, L.U. (1989). Mass media, people and politics in Nigeria. Concept Publishing Company: New Delhi.

WJEC. (World Journalism Education Congress), Declaration of journalism principles. Retrieved on 17th February, 2011, at http://wjec.ou.edu 


\title{
Como lidar com clientes difíceis. Uma releitura do trabalho do Dr. Rick Brinkman e Dr. Rick Kirschner voltado para o atendimento ao cliente
}

\author{
Guilherme Dias \& Marcos Isern \\ UNIARA
}

E-mail: gui.gdelive.com/monteararaquaraeterra.com.br

\begin{abstract}
Resumo
Indiferente do meio de compra, seja ele

tudos destes autores para entender mefísico ou não, enfrenta-se sérios problemas com relação a clientes com comportamentos difíceis, principalmente quando não conseguem satisfazer suas necessidades e intenções. Dr. Rick Brinkman e Dr. Rick Kirschner estudaram o comportamento humano para entender melhor comportamentos difíceis e conseguiram classificar dez comportamentos difíceis de lidar baseados em suas intenções e o foco em que cada um deles direciona. O objetivo desse trabalho é utilizar os eslhor o comportamento do nosso cliente quando suas necessidades não são satisfeitas, gerando assim desconforto e comportamentos mais agressivos com relação à venda, seja ela de um produto físico ou serviço. Assim, o trabalho explica a pesquisa de Brinkman e Kirschner, relembra os conceitos de marketing que norteiam o comportamento do consumo e depois elabora um plano estrateégico para lidar com esses comportamentos difíceis, que virarão consumidores difíceis.
\end{abstract}

Palavras-chave: marketing; comportamento de consumo; comportamentos difíceis; consumidores difíceis; consumo; comportamento humano.

\section{Dealing with difficult clients. Revisiting the work of Dr. Rick Brinkman and Sr. Rick Kirschner on customer satisfaction}

\begin{abstract}
Regardless of the means of purchase, with difficult behaviors, especially when whether physical or not, one can face se- the seller cannot meet their needs and inrious problems with regard to customers tentions. Dr. Rick Brinkman and Dr.
\end{abstract}


Rick Kirschner studied human behavior to better understand difficult behaviors and managed to rank ten difficult behaviors, based on their intentions and focus. The aim of this work is to use the studies of the authors to better understand our customer's behavior when their needs are not met, thus generating discomfort and more aggressive behavior with respect to the sale, be it a physical product or service. Thus, the work explains the research of Brinkman and Kirschner, recalls the marketing concepts that guide the consumption behavior and then draw up a strategic plan to deal with these difficult behaviors, which will turn into difficult customers.

Keywords: marketing; consumer behavior; difficult behaviors; difficult customers; consumer; human behavior.

\section{Introdução}

$\mathrm{Q}$

UANDO falamos de comportamento de consumo, não podemos esquecer que antes de qualquer coisa existe o comportamento humano, que norteia todo o comportamento de consumo e faz com que o cliente finalize ou não a tarefa de comprar. Isso significa que estudar o comportamento de consumo significa entender o comportamento humano baseado em suas intenções e definir melhor quais ações utilizaremos para atingir nosso público alvo.

Assim, entender o comportamento do consumidor por uma abordagem da psicologia pode nos levar a ter mais sucesso em nossas vendas, principalmente quando se trata da relação cliente $\mathrm{x}$ vendedor. É necessário entender o comportamento humano para escolher a melhor abordagem de vendas. Podemos dizer que o comportamento de consumo é reflexo do comportamento humano e diário que faz com que o indivíduo compre ou não o produto, o serviço ou a ideia proposta.

Dr. Rick Brinkman e Dr. Rick Kirschner realizaram um estudo baseado na intenção e assertividade humana para entender melhor o comportamento humano. Eles chegaram à conclusão de que existem dez comportamentos difíceis de lidar, mas que podem ser trabalhados e entendidos. Não que exista somente esses dez comportamentos difíceis, mas é um norte para entender melhor os motivos que levam alguém a reagir de maneira mais agressiva ou não. 
Para esse projeto propõe-se um estudo de comportamento de consumo trazendo para o Marketing as descobertas do Dr. Rick Brinkman e Dr. Rick Kirschner. Com essa abordagem e os estudos de Philip Kotler, o objetivo deste trabalho é entender esses comportamentos e como fazer com que eles não atrapalhem as vendas, ou que sejam ferramentas de auxílio na hora de fechar um negócio. Portanto, trata-se de entender o comportamento humano, aos olhos do Dr. Rick Brinkman e Dr. Rick Kirschner, entender o que o Marketing nos propõe com relação ao comportamento de consumo e unir os dois estudos para lidar melhor com clientes difíceis.

\section{Consumo}

Assim, é necessário entender o consumo do ponto de vista do marketing para que haja um entendimento melhor do comportamento do consumidor. $\mathrm{O}$ consumo pode ser de algo físico (um carro ou um sapato) ou de um serviço (curso de Inglês ou massagens terapêuticas). Segundo Kotler (1994), "Marketing é um processo social e administrativo pelo qual indivíduos e grupos obtêm o que necessitam e o que desejam através da criação e troca de produtos e valor com outras pessoas".

\section{Visão Geral do Consumo}

O marketing tem se utilizado de ferramentas diferentes para se adaptar aos novos consumidores, que aliado às novas tecnologias, têm ampliado o poder de compra e negociação. O marketing tem acompanhado as mudanças de época e de público em que se encontra. A figura 1 (Evolução do Marketing) mostra como o marketing foi evoluindo até a década de 90 . 
Figura 1. Evolução do Marketing

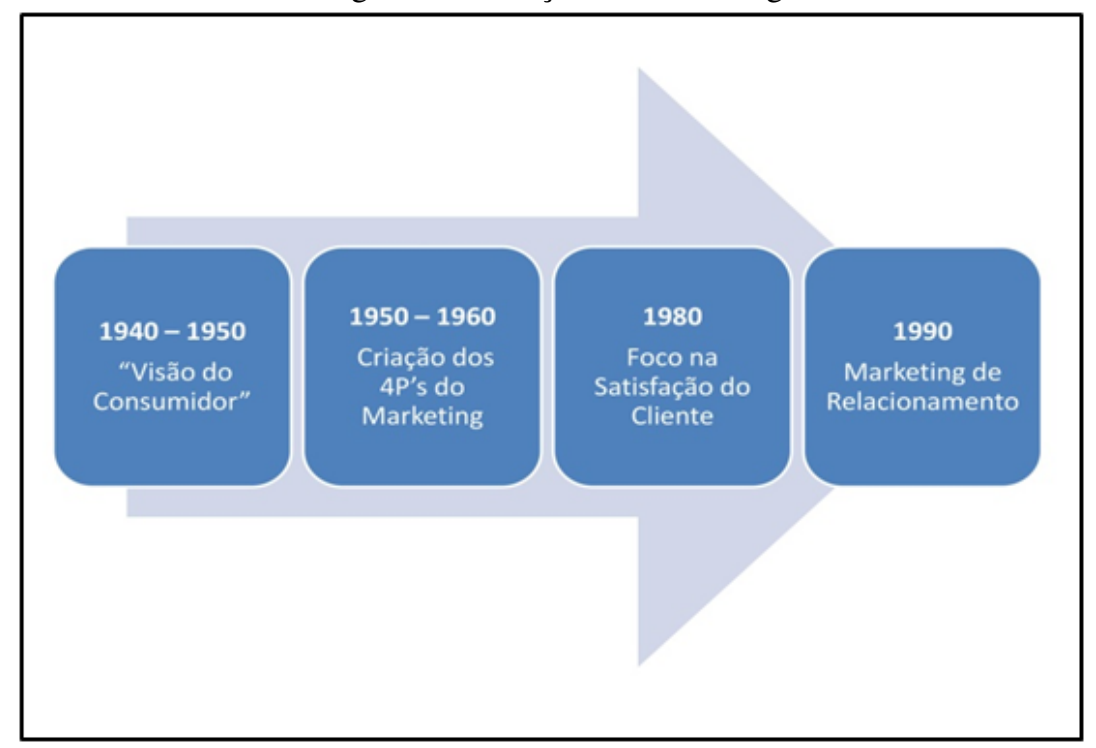

A partir dessa data, a era da tecnologia começou a dominar os consumidores e a necessidade da criação de novos conceitos de marketing foi sendo suprida, como é o caso do "marketing digital" que surge devido o crescimento da tecnologia na vida do consumidor, o que o faz tomar decisões diferenciadas com relação a compra de um produto ou serviço.

Em resumo, o marketing não mudou e a necessidade de se ter um produto ou utilizar um serviço também não mudaram. O que muda é a perspectiva dos produtos e a forma como a empresa levará essa informação até o consumidor, para que esse possa adquirir seu produto ou serviço. Temos lados positivos e negativos com relação a toda essa mudança. Um exemplo disso é o aumento dos meios de comunicação que fazem com que o consumidor final fique sabendo do produto ou serviço mais rápido (por meio de tablets, smartphones, entre outros dispositivos eletrônicos). Isso aumenta a concorrência e pode fazer com que a qualidade no atendimento tenha uma queda perceptível para o cliente, já que há uma necessidade no corte de custos e na venda em massa para poder suprir toda a necessidade da empresa. 
Por esse e outros motivos, o marketing deixou de ser tradicional para assumir uma forma mais "engajadora", que chamaremos de "marketing de engajamento", no qual a marca cria um relacionamento direto com o consumidor para que este possa opinar e fazer com que a empresa crie um relacionamento mais duradouro com seus clientes de um modo que eles não se sintam violados no seu direito de opinar ou trocar de marca. No livro escrito pelo CEO da Constant Contact, "Engagement Marketing: How Small Business Wins in a Socially Connected World" (Gail F. Goodman, 2012)8, o autor classifica três pontos que devem ser seguidos para que o marketing de engajamento seja um sucesso, os quais são: 1) criar uma experiência inovadora no cliente; 2) montar estratégias para que o cliente mantenha contato usando sua experiência inicial, e 3) engajar pessoas com conteúdos que as inspirem e as coloquem numa posição ativa de propagar a marca. Baseado nesses três passos, o autor simplifica a maneira de se utilizar o marketing de engajamento. Por esse meio, o envolvimento do cliente com a marca passa a ser maior refletindo o que a marca tanto espera: fidelização do cliente. A figura 2 (Marketing de Engajamento) mostra alguns pontos que foram mudando para que o marketing de engajamento ganhasse espaço.

Figura 2. Marketing de Engajamento

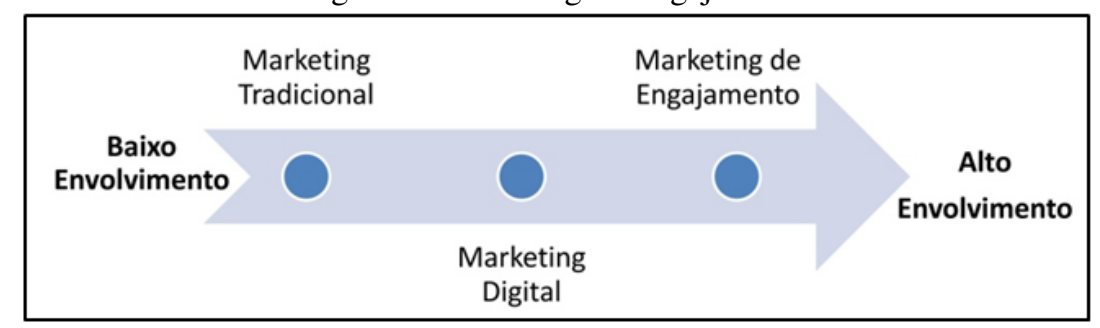

Como exemplos, podemos citar a televisão, os jornais e o rádio como forma de comunicação do marketing tradicional. Já no marketing digital, podemos citar sites, e-mails, redes sociais, entre outro. O que difere o marketing digital do marketing de engajamento é a comunicação entre empresa e consumidor para torná-lo cada vez mais fiel a sua marca, ou seja, a marca cria um "diálogo" para atender melhor seu cliente. 


\section{O Consumidor}

O consumidor por sua vez tem assumido novas abordagens de compras, já que a tecnologia trouxe uma série de novas possibilidades de comunicação. Pode-se entender melhor lembrando que os canais de venda eram muito reduzidos e cresceram em uma velocidade rápida. $\mathrm{O}$ ambiente corporativo, que antes ficava distante do consumidor final, foi se aproximando dele pelas ferramentas sociais, tornando o consumidor mais participativo e exigente. Isso faz com que o maior desafio das empresas seja fidelizar os clientes entendendo esse cenário.

O consumidor, ao longo do tempo, passou por uma transformação bastante significativa que acompanha a evolução da tecnologia e das mídias sociais. O consumidor tinha apenas um canal de compra, ou seja, a loja que tinha o poder do produto. Quando a era digital começou a ganhar força, o cliente se transformou em um "consumidor multicanal", pois poderia fazer compras pelo telefone, e um pouco mais tarde pela internet também. Com a popularização das redes sociais e o crescente número de aparelhos tecnológicos, o consumidor passa a ser chamado de "omni-channel" pelo e-commerce, pois além de comprar pelo smartphone, utiliza as redes sociais para dar suas opiniões, fazer seus pedidos e se comunicar diretamente com o fabricante do produto.

O consumidor passa a ter o poder total do produto, que antes era do estabelecimento que o vendia. Ele pode fazer uma revolução em uma marca por apenas colocar suas opiniões em uma rede social e essa se tornar um marketing viral. Um exemplo bem prático com relação a isso é o ocorrido com a Coca-Cola e o rato12. Um consumidor postou uma foto onde aparecia um rato dentro de uma garrafa de Coca-Cola. Na época virou marketing viral e todos só falavam dos ratos que poderiam estar em outras garrafas. A CocaCola resolveu esperar laudos que comprovassem o que o consumidor havia reclamado, e o resultado foi que a história era falsa. Mesmo o fato não sendo verídico o consumidor que começou essa história utilizou de redes sociais para isso, fazendo com que a história fosse transmitida em tempo rápido para uma quantidade muito grande de pessoas.

Fernando Lucena, consultor e presidente do Grupo Friedman, nos apresenta uma maneira de entender melhor nosso comportamento moderno, que ele chama de "Matemática do Novo Consumidor"11, que segue a seguinte or- 
dem: o atual consumidor tem menos tempo (T) e gasta menos dinheiro (D) em suas compras, porém tem mais opções (O) de escolha e informações (I) sobre os produtos. O resultado dessa matemática é o que ele chama de Potencial de Compra (PC). Veja modelo:

$$
\mathrm{PC}=\mathrm{T}(-)+\mathrm{D}(-)+\mathrm{O}(+)+\mathrm{I}(+)
$$

\section{A Empresa}

A empresa por sua vez tem o papel de fornecer o produto e/ ou serviço ao consumidor final. Essa é uma visão bem simplificada do papel da empresa no processo do comportamento do consumidor. A empresa exerce um papel mais que fundamental pois ela também fornece tudo aquilo que vai envolver o cliente para leva-lo a finalizar sua compra.

Os 4 Ps do marketing9 descrevem bem a importância da empresa com relação ao comportamento de consumo. Cada "P" influencia de alguma maneira a escolha que o consumidor vai fazer com relação à compra e pode significar um avanço na conquista de mercado e na consolidação da marca.

- PRAÇA: se refere ao local onde o produto está disponibilizado para que o cliente compre. Nesse caso pode ser em um espaço físico ou online, dependendo do segmento da loja e do produto;

- PREÇO: refere-se ao valor atribuído ao produto, sabendo que esse pode variar dependendo do material que é fabricado até o valor que é gerado por uma marca e pela sua representação no mercado;

- PRODUTO: refere-se às características do produto e seu diferencial para que esse possa ser comercializado;

- PROMOÇÃO: refere-se a como o produto será conhecido pelo seu público-alvo. Um exemplo de promoção é uma campanha feita pelo Facebook para divulgar um novo produto da marca ou uma atualização do mesmo.

É importante lembrar que todos os pontos são planejados baseados no tipo de cliente que se deseja atingir. Assim, o PREÇO pode ser menor porque a classe atingida é a classe D e E, fazendo com que todos os outros Ps tenham de ser adaptados para essa realidade. Nesse caso, os estabelecimentos que venderiam esse produto (PRAÇA) devem ser em locais onde a concentração dessa classe seja maior. O PRODUTO pode ser de qualidade inferior por redução de 
custos e os meios de como esses produtos serão conhecidos (PROMOÇÃO) podem ser de diversas formas, inclusive pela internet. A Figura 3 resume algumas questões que cada $\mathrm{P}$ do Mix de Marketing traz consigo para que possa ser mais eficaz na hora do planejamento.

Figura 3. Marketing Mix

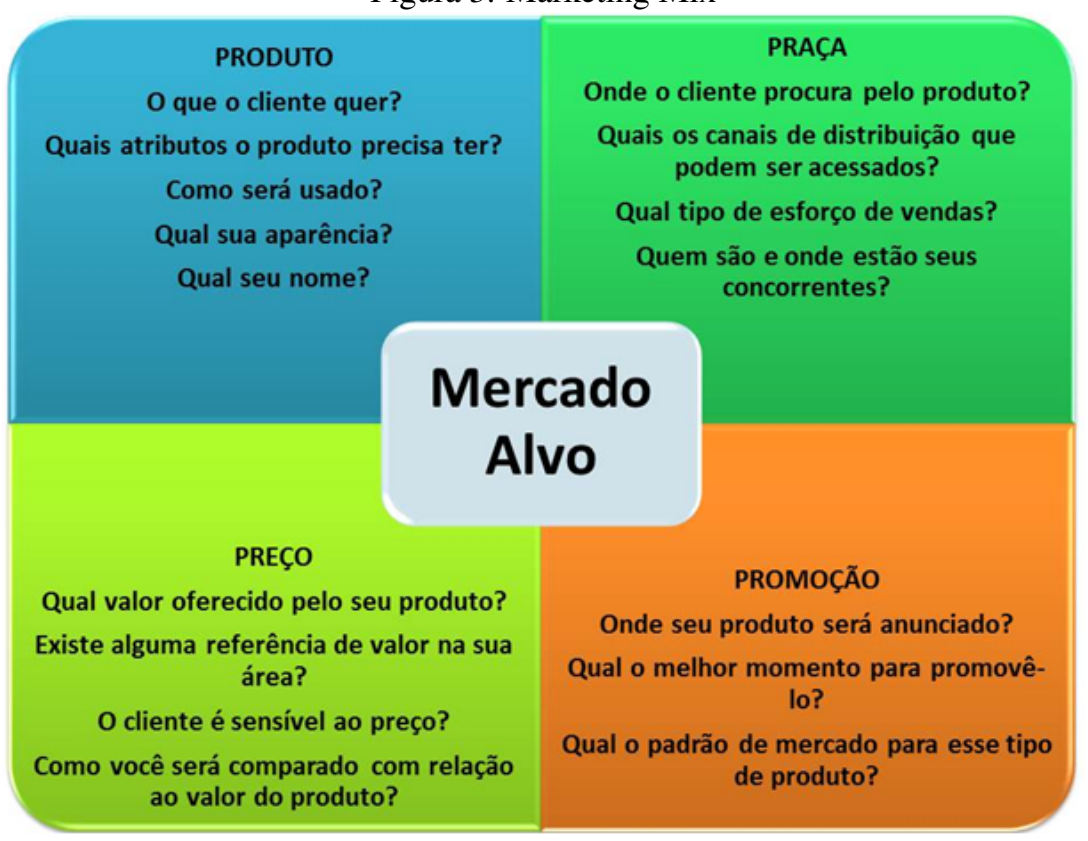

Além do Mix de Marketing, o autor Conrado Adolpho, criou os 8 Ps do Marketing Digital para que houvesse mais ferramentas a serem usadas com o avanço da tecnologia. Isso auxilia a empresa na hora de pensar em ações de marketing digital, sejam elas em qual "P" do Mix de Marketing ela esteja focada ou planejando.

- PESQUISA: direcionar os esforços com base no comportamento online do consumidor;

- PLANEJAMENTO: para definir como o site da empresa se transformará em uma ferramenta de negócios;

- PRODUÇÃO: executar o planejamento estipulado no segundo P; 
Como lidar com clientes difíceis. Uma releitura do trabalho do Dr. Rick Brinkman e Dr. Rick Kirschner voltado para o atendimento ao cliente

- PUBLICAÇÃO: escolher conteúdos com as diretrizes da SEO (Search Engine Optimization);

- PROMOÇÃO: produzir conteúdos importantes que possam se tornar virais;

- PROPAGAÇÃO: provocar o compartilhamento de todo o processo descrito antes;

- PERSONALIZAÇÃO: criar relacionamento por meio da personalização feita pela segmentação do público-alvo;

- PRECISÃO: medir os resultados obtidos para auxiliar nos próximos planejamentos.

Como visto, o sistema criado pelo Conrado Adolpho se trata de um ciclo que deve ser seguido para que o sucesso seja atingido. O marketing digital não descarta as ferramentas do marketing tradicional, mas tem a necessidade de adaptar algumas e criar novas para atender o público que vem incorporando no seu dia-a-dia a tecnologia como estilo de compras. A figura 4 exemplifica esse sistema criado por Conrado Adolpho.

Figura 4. 8 Ps do Marketing Digital

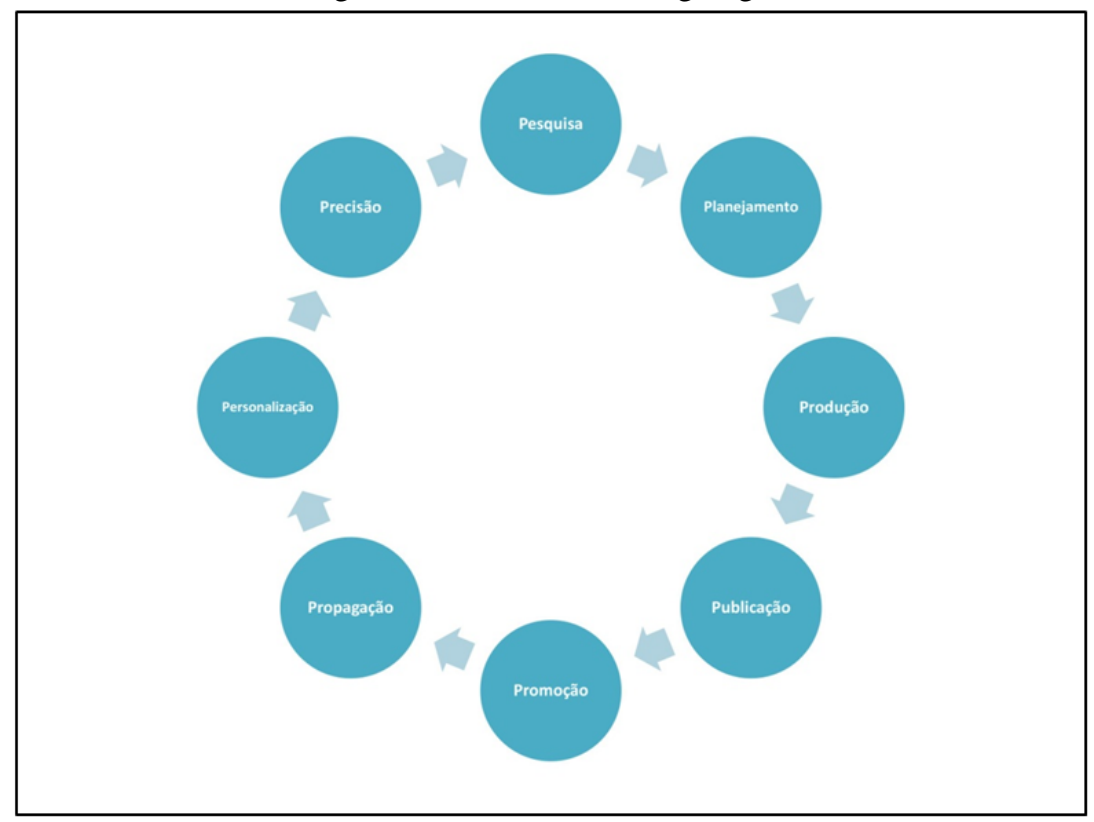




\section{O Atendimento}

Pode-se assim entender que o atendimento depende de uma série de fatores para que se tenha sucesso nas vendas. $\mathrm{O}$ atendente (ou o vendedor) é a ponte entre o cliente e a empresa. Mesmo em situações de compras online, existe alguém que vai servir de suporte para que essa compra seja efetuada. Segundo a Sociedade Brasileira de Coaching, um bom atendimento depende de sinceridade, transparência, satisfação, entender o outro lado, desenvolvimento de pós-venda e fazer com que o cliente se sinta à vontade. Esses pontos servem como ponto de partida para que o atendimento seja eficaz e eficiente. Além disso, a empresa deve fornecer uma boa estrutura para que o atendente possa exercer sua função da melhor maneira possível. Isso significa que mesmo que o colaborador tenha excelentes técnicas de vendas, se a empresa não lhe der um bom suporte (pode-se citar aqui um treinamento específico sobre os 4 Ps do marketing para aquele produto, boa remuneração, possibilidade de crescimento interno, entre outros), a venda pode não acontecer.

O cliente, com tantas opções, já não é mais aquele que passa despercebido por um erro cometido pela empresa ou pelo vendedor. Com as ferramentas de mídias sociais, o cliente tem muito mais poder que antes e o atendimento deve sempre prezar por uma qualidade para seja referencial da empresa. $\mathrm{O}$ site Reclame Aqui é um exemplo de uma ferramenta que mostra o quanto os atendimentos tem sido insatisfatórios por diversos motivos. Por isso, é necessário se atentar a todas as etapas do processo de uma venda para que o cliente esteja satisfeito e seja fidelizado.

Portando o consumo sempre terá o mesmo objetivo: a venda e compra de um produto ou serviço. O que muda é a necessidade de se adaptar a novas tecnologias e públicos que podem ou não fechar a compra por algum motivo. As novas ferramentas estão sendo cada vez mais aperfeiçoadas para que a compra satisfaça a necessidade e o desejo do cliente.

\section{Comportamentos}

A pesquisa citada nesse trabalho foi baseada nas experiências do Dr. Rick Brinkman e do Dr. Rick Kirschner, estudantes do comportamento humano e palestrantes motivacionais, que se juntaram para fazer uma pesquisa sobre 
Como lidar com clientes difíceis. Uma releitura do trabalho do Dr. Rick Brinkman e Dr. Rick Kirschner voltado para o atendimento ao cliente

comportamentos difíceis. Sua pesquisa foi baseada em estudos e relatos de clientes que atendiam individualmente para desenvolvimento pessoal e profissional.

\section{Intenções}

Segundo Dr. Rick Brinkman e Dr. Rick Kirschner, o que norteia o comportamento do ser humano são suas intenções. Para definir melhor essas intenções, eles se utilizam de dois pontos importantes no comportamento humano: o nível de assertividade e o foco de atenção. Todo ser humano tem um ambiente que os doutores chamam de "zona de normalidade" que é quando elas conseguem lidar com as situações sem que seus comportamentos sejam difíceis e, muitas vezes, incontroláveis.

O nível de assertividade diz respeito ao quanto à pessoa é agressiva ou passiva com relação a suas atitudes. Enquanto o foco de atenção diz respeito a que direcionamento está sua ação: se é na tarefa ou nas pessoas.

Observe a imagem (Figura 5 - Zona de Normalidade) que descreve esse ambiente de "zona de anormalidade", assertividade e foco de atenção.

Figura 5. Zona de Normalidade

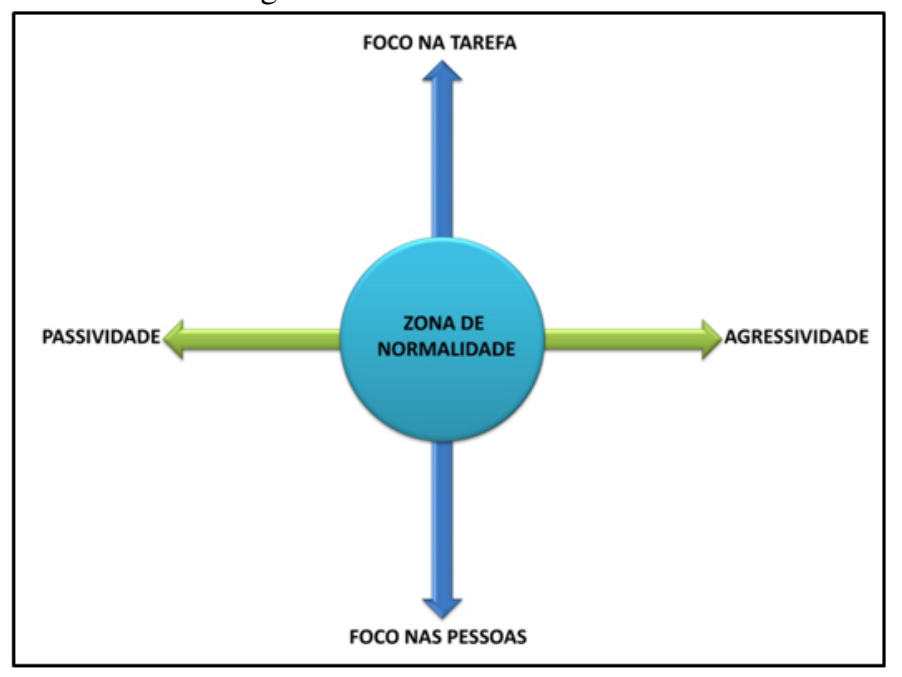


Baseado nessa imagem, podemos classificar quatro intenções positivas, dependendo do grau de assertividade e foco de atenção. A zona de normalidade significa o espaço em que o indivíduo consegue se controlar e suprir suas intenções sem problema algum.

$\mathrm{O}$ indivíduo que é focado na tarefa e tem sua assertividade mais passiva, tem a intenção de "fazer as coisas certas", já o que é mais agressivo em sua assertividade, a intenção é de "finalizar a tarefa". Aqueles com foco em pessoas e assertividade mais passiva tem a intenção de "integrar-se às pessoas", já o mais agressivo tem sua intenção de "ser reconhecido". Não existe nada de errado nessas intenções e comportamentos. Para simplificar, veja a figura 6 (Intenções Positivas) como elas se encaixam no quadro da zona de normalidade.

Figura 6. Intenções Positivas

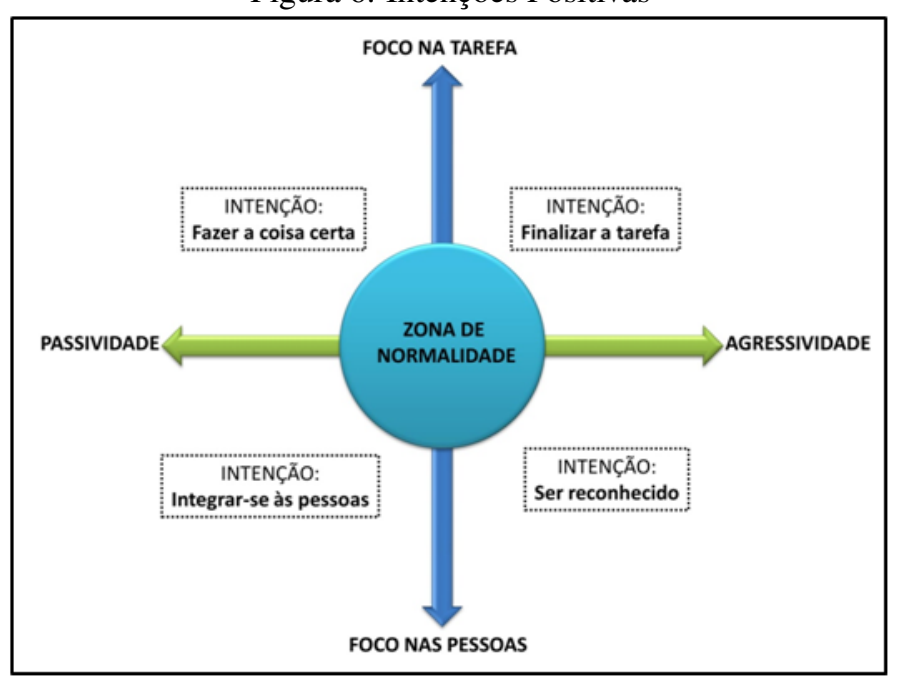

- Finalizar a Tarefa: seu objetivo é finalizar aquilo que começou. Não que os outros pontos não importam, mas seu foco é fazer com que a tarefa seja finalizada no prazo estipulado, não pensando em detalhes ou pessoas.

- Fazer a coisa certa: pode-se até cumprir o prazo, mas enquanto não tiver segurança o suficiente em que a tarefa foi realizada da maneira correta, 
a intenção não satisfeita, por isso, pode até atrasar tarefas e não pensar tanto nas pessoas.

- Integrar-se às pessoas: pode deixar seus desejos de lado para atender o desejo das outras e se sentir parte do grupo.

- Ser reconhecido: o objetivo é buscar reconhecimento. Esse reconhecimento pode vir de diversas formas. Quando o reconhecimento acontece de fato, essa intenção pode tirar suas energias da tarefa e, assim, entregar fora do prazo ou até mesmo contendo erros.

Não há nada de errado nessas intenções ou os comportamentos que elas norteiam. O problema está quando essas intenções não são supridas e acabam saindo da Zona de Normalidade e entram na Zona de Estresse, ou Zona Cinzenta, como diz Dr. Rick Brinkman e Dr. Rick Kirschner.

\section{Comportamentos Difíceis}

Deve-se lembrar de que, segundo o behaviorismo, as pessoas podem associar as respostas de estresse dependendo da experiência que tiveram no passado visto que estas situações as prejudicaram ou causaram certo estresse. Essa é uma fobia clássica que pode ser desenvolvida. Um exemplo seria um aluno que não passou no exame final e pode ter algum tipo de reação de estresse quando entrar na sala onde fez a prova, por associar a sala a um local de estresse e fracasso. Alguns comportamentos difíceis são apenas reações naturais do indivíduo que desenvolveu esse medo por algum motivo, e os medos podem custar a desaparecer. Como não sabem enfrentar ou lidar com a situação, acabam fugindo dela e apresentando algum tipo de comportamento que pode ser difícil de lidar.

A Zona de Estresse, ou Zona Cinzenta, se caracteriza pela não realização das intenções. Cada indivíduo reagirá de uma maneira em determinada situação, mas seu comportamento será difícil porque, além de sua frustração, ele vai usar "armas" que podem prejudicar o relacionamento com outras pessoas e qualquer processo em que esteja envolvido, seja de planejamento ou de venda. Observe na Figura 7 (Zona Cinzenta), onde isso pode ocorrer. 
Figura 7. Zona de Estresse (ou Zona Cinzenta)

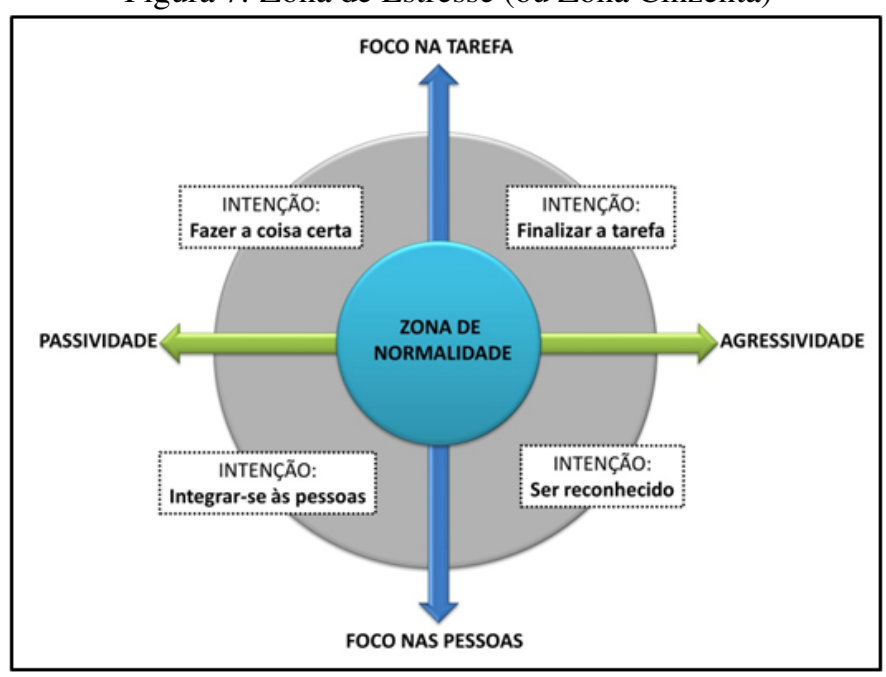

Isso significa que a intenção da pessoa não foi realizada, portanto, ela entra em uma zona de estresse onde pode desenvolver um comportamento difícil e muitas vezes destrutivo psicologicamente. Assim, quando a intenção de "fazer a coisa certa" não é realizada, o estresse se volta para o perfeccionismo, assim como a intenção de "finalizar a tarefa" se volta para o controle, a intenção de "integrar-se às pessoas" se torna uma conquista à aprovação e de "ser reconhecido" se torna um desejo de atrair a atenção dos outros. 
Figura 8. Intenções não realizadas

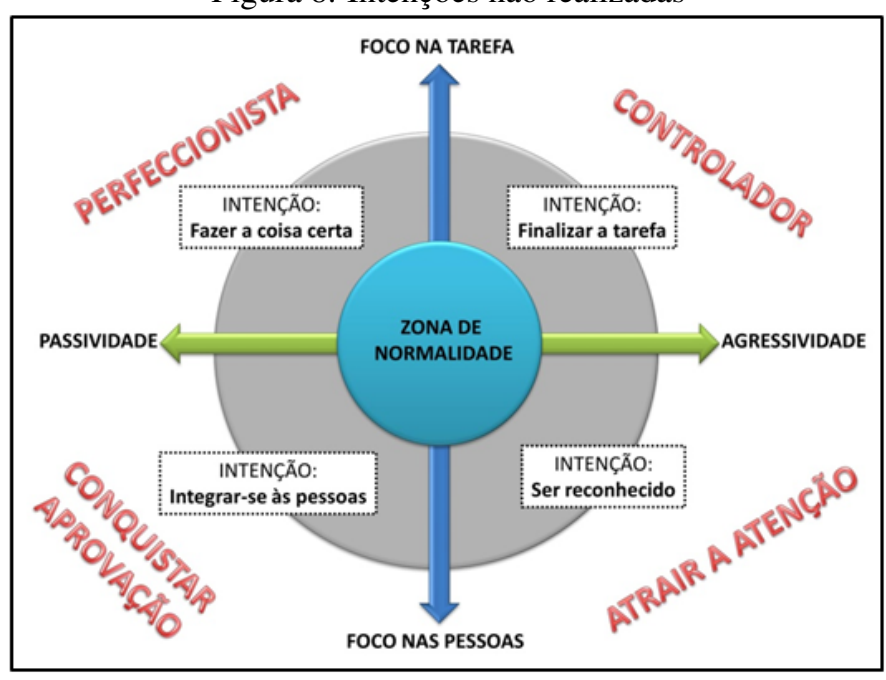

Baseado nessas intenções não realizadas, os autores classificaram dez comportamentos difíceis. Abaixo, a lista dos dez comportamentos e um resumo de cada comportamento.

- O tipo "tanque de guerra": agressivo e, para ele, os fins justificam os meios. Você será eliminado se estiver em seu caminho. Você acaba se tornando o obstáculo quando se interpõe entre ele e o objetivo, e isso não é nada pessoal.

- O tipo "atirador de elite": dissimulado, acumula informações negativas contra você para usar em momentos de estresse. Não atira para todo lado, sabe bem quem quer atingir. E o faz pelo mesmo motivo do "tanque de guerra": eliminar obstáculos.

- O tipo "granada": com seus acessos de raiva, explode como uma granada sem ver quem está atingindo. Isso acontece na mesma maneira de uma granada: primeiro se tira o pino, depois ele explode do nada e atinge até mesmo quem não tem nada a ver com a situação.

- O tipo "sabe-tudo": sabe de quase tudo, passa horas falando dos seus conhecimentos, mas não dará ouvido para o que você precisa falar ou comunicar, por achar a opinião dos outros inferior. Seria um jeito de 
fazer com que os outros se calem, já que ele os percebe como um obstáculo também.

- O tipo "ele-pensa-que-sabe-tudo": pensam que sabem tudo e se você deixá-los conduzir as ações sem conhecimento do assunto pode levar o projeto a falência já que eles não sabem muito do assunto. Comportamse assim para que você dê atenção a eles.

- A pessoa "sim": faz de tudo para agradar a todos dizendo "sim" para tudo. São lentas para agir e geralmente não cumprem o que prometem por terem dificuldade em dizer "não" e priorizar tarefas. As tarefas acabam se tornando obstáculos para, positivamente, chamar a atenção.

- A pessoa "talvez": tem dificuldade em tomar decisões, então elas esperam que as decisões se resolvam por si só. Assim elas não correm o risco de chatear ninguém, pelo menos é o que elas pensam.

- A pessoa "nada": não dá feedback algum porque não faz nada, fica como "invisível". Essa é uma maneira que eles encontram para não dispor com a outra pessoa.

- A pessoa "não": desencorajador, usa a desculpa de estar sendo realista e não pessimista, mas acaba atrapalhando o andamento de projetos com seus desesperos negativos.

- O "reclamador": afundado em um mar de desilusões, reclama de tudo da vida e não faz nada. Em seus entendimentos, tudo dará errado até que alguém faça alguma coisa para mudar isso. Assim, acha que não será culpado quando tudo sair errado.

Esses dez comportamentos podem ser vistos em diversas intenções não realizadas. Observe a figura 9 (comportamentos difíceis), onde estão os comportamentos difíceis gerados em cada intenção não realizada. 
Como lidar com clientes difíceis. Uma releitura do trabalho do Dr. Rick Brinkman e Dr. Rick Kirschner voltado para o atendimento ao cliente

Figura 9. Comportamentos Difíceis

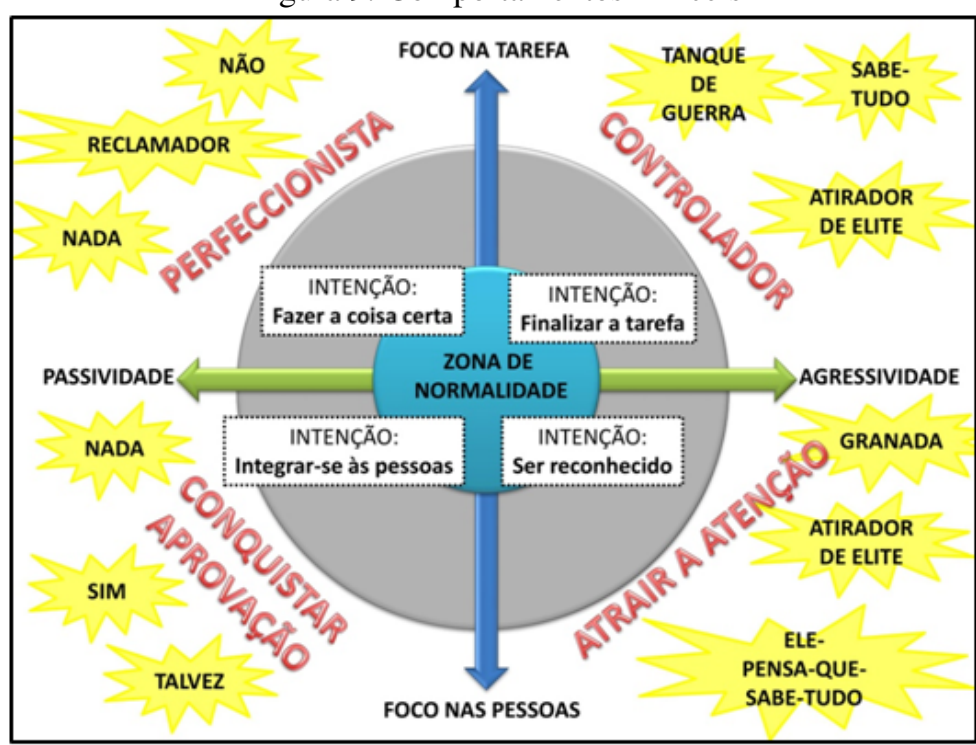

Baseado na imagem anterior pode-se entender melhor quais intenções não foram satisfeitas para que o comportamento gerasse um estresse. Segue tabela com um breve resumo das intenções, dos comportamentos difíceis e qual a reação que esse comportamento pode ter como sinal da intenção não satisfeita. Vale lembrar que essa é uma pesquisa comportamental e que pode haver outras que podem complementar esse estudo. 
Tabela 1. Intenções, Comportamentos Difíceis e Possíveis Reações

\begin{tabular}{|c|c|c|}
\hline \multicolumn{1}{|c|}{ Intenção } & Comportamento & Possível Reação \\
Finalizar a Tarefa & Tanque de Guerra & Violência \\
\hline Finalizar a Tarefa & Atirador de Elite & Comentários virulentos \\
\hline Finalizar a Tarefa & Sabe-Tudo & Aulas autoritárias \\
\hline Fazer a Coisa Certa & Reclamador & Lamentos \\
\hline Fazer a Coisa Certa & Pessoa "não" & Negatividade \\
\hline Fazer a Coisa Certa & Pessoa "nada" & Passividade \\
\hline Integrar-se às Pessoas & Pessoa "nada" & Passividade \\
\hline Integrar-se às Pessoas & Pessoa "sim" & Afabilidade \\
\hline Integrar-se às Pessoas & Pessoa "talvez" & Indecisão \\
\hline Ser Reconhecido & Granada & "Barullhos" \\
\hline Ser Reconhecido & Atirador de Blite "amigável" & Piadas corrosivas \\
\hline Ser Reconhecido & Ble-Pensa-Que-Sabe-Tudo & Orgullho \\
\hline
\end{tabular}

"Se você trabalha com pessoas difíceis, saiba que há uma boa e má notícia. A má é que você trabalha com elas. A boa é que você tem tempo para estudá-las, entender seus padrões de comportamento e planejar uma resposta estratégica." (Dr. Rick Brinkman e Dr. Rick Kirschner, pg. 77, 2006)

\section{Lidando com clientes difíceis}

\section{Identificando as Necessidades e os Desejos do Cliente}

Segundo Abraham Maslow, as necessidades humanas são divididas e classificadas em forma de pirâmide. 
Figura 10. Pirâmide das Necessidades Humanas

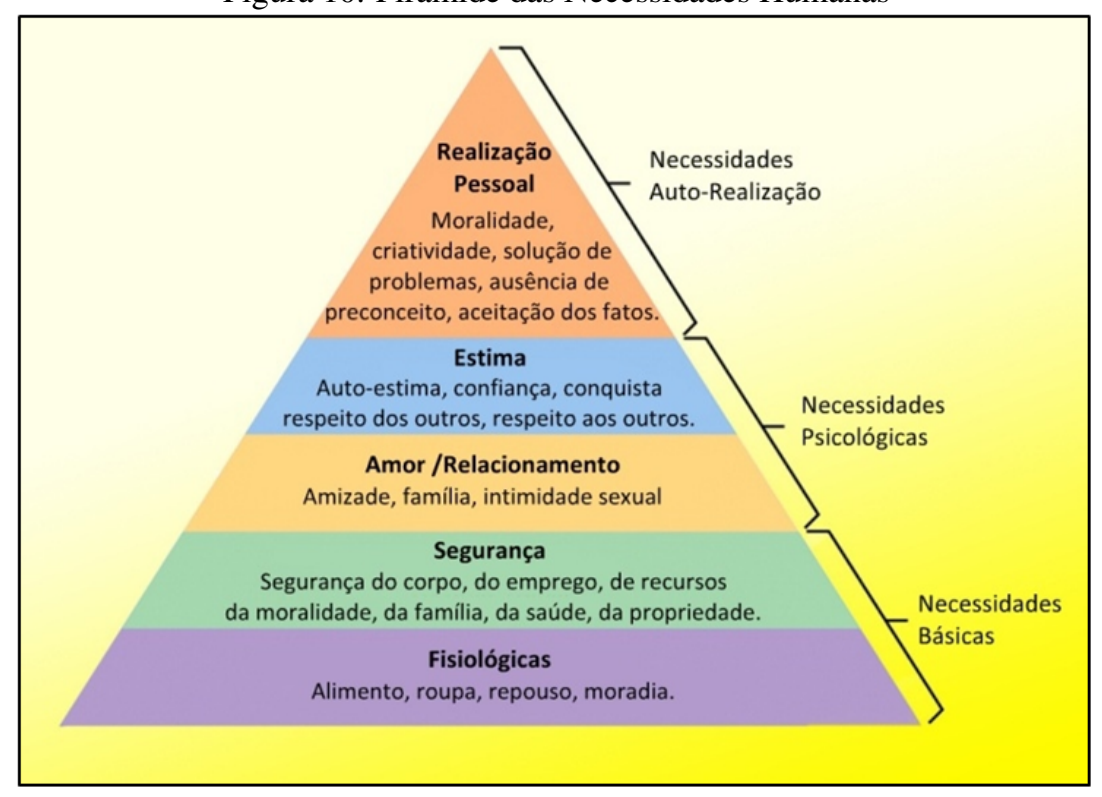

O que se deve destacar é que as necessidades humanas são colocadas em forma de pirâmide porque se a base não for satisfeita, o restante não serão também, ou serão apenas parcialmente. O cliente pode procurar um produto para satisfazer qualquer necessidade da pirâmide. Vale resaltar que necessidade é o que ele precisa para sobreviver, enquanto desejo é o que ele prefere. Um bom exemplo é a comida. O ser humano tem a necessidade de comer quando está com fome, porém pode optar por comer em um restaurante de fast-food ou cozinhar em casa, dependendo do seu desejo. Um dos papéis do marketing é também estimular desejos para que o cliente adquira o produto ou serviço que é oferecido.

O entendimento deve ser feito com muita cautela para que o cliente esteja satisfeito com a compra e se fidelize na marca ou loja, e isso pode significar que sua necessidade não esteja em comprar um determinado produto. Com a falta de diálogo nos dias de hoje alguns clientes se tornam fiéis a certos estabelecimentos porque recebem a atenção que necessitam, logo acabam comprando algo que desejam, seja um sapato, um livro ou até mesmo se matricular em um curso. Por isso, há a necessidade de entender o cliente e perceber 
aquilo que ele necessita e o que ele deseja naquele momento, para que o produto e o serviço prestado possam ir de encontro com o que ele busca.

\section{Satisfazendo o Cliente}

Satisfazer o cliente significa entender sua realidade e oferecer aquilo que ele necessita e deseja. O cliente deve ser ouvido e ter suas dúvidas sanadas para que o vendedor possa compreendê-lo melhor e fazer com que este se fidelize na marca. Portanto, cabe ao vendedor ter habilidades específicas de atendimento, como saber ouvir e fazer perguntas certas, para que seu trabalho seja feito de forma eficaz e eficiente. Nem todo cliente fechará a venda, mas levará consigo a impressão que teve do atendimento, do clima do estabelecimento, da organização e de todos os detalhes possíveis, mesmo que inconscientemente.

O maior problema é que as metas têm sido consideradas necessidades primárias das organizações. Com isso, o atendimento se torna cada vez menos satisfatório e o cliente, sabendo da possibilidade de opções, acaba comprando em outro local. Isso se deve a diversos fatores, entre eles má condições de trabalho, má remuneração, líderes que não compreendem as necessidades básicas dos colaboradores. Segundo PROCON, em 2014, as empresas que mais tiveram reclamações de atendimento foram as de telefonia. As reclamações vão desde cobranças indevidas, até problemas com aparelhos e sinais.

$\mathrm{O}$ grande diferencial das empresas pequenas tem sido o atendimento, segundo pesquisa do SEBRAE de 2014, pois prezam por um atendimento individualizado para compreender melhor a necessidade e o desejo do cliente. Segundo artigo publicado na Business Analytics de Portugal, em 23 de fevereiro de 2015, o consumidor moderno tem 7 características: compras a contra-relógio, controle, compras por diversos canais, consumidores de conteúdo, experiência global, colaboradores e social shares. Sahal Laher, vicepresidente executivo e Chief Information Officer, Brooks Brothers, disse sobre e-commerce: "Não importa onde está a fazer as suas compras, o consumidor é o consumidor. Há que quebrar as barreiras entre canais, capacitar o consumidor de forma uniforme e envolve-lo no seu site como se estivesse na sua loja." 


\section{Como Lidar com Clientes Difíceis}

Segundo Dr. Rock Brinkman e Dr. Rick Kirschnerr, existem dicas básicas para lidar com comportamentos difíceis antes de apontar a melhor reação para os dez comportamentos citados por eles.

- Reduza as diferenças: as diferenças não devem ser vistas como obstáculos, mas como desafios a serem reduzidos para que a comunicação seja clara e todos possam compreender melhor e atender as necessidades ou desejos do cliente. Estabelecer afinidades pode ser uma maneira de reduzir diferenças, lembrando sempre que o profissionalismo deve sempre vir em primeiro lugar. E isso significa transformar as diferenças em cooperação. Afinal de contas, o objetivo da venda é a mesma: o cliente comprar, e o vendedor vender.

- Escute para ser realmente entendido: isso significa que se deve escutar antes de fazer com que o cliente entenda a marca ou o produto. Para isso, é necessário fazer perguntas para que o cliente possa expressar aquilo que realmente necessita. A discussão acontece porque duas pessoas querem ser ouvidas e ninguém quer escutá-las. Saber escutar pode abrir caminhos para novos negócios.

- Atinja uma compreensão mais profunda: não se deve aceitar um comportamento ou simplesmente ser preconceituoso com relação a isso. A compreensão faz com que novos caminhos sejam direcionados para a solução do problema. Para isso, é necessário estudar e estar sempre atento aos sinais que demonstram os desejos e as necessidades do cliente.

- Fale para ser compreendido: depois de escutar e compreender o cliente, uma conversa com bons argumentos é a solução para que o cliente não se sinta ameaçado. As cinco técnicas apresentadas pelos autores da pesquisa são: monitore seu tom de voz, apresente sua intenção principal, interrompa diplomaticamente, diga a sua verdade e seja flexível.

- Projete e espere o melhor das pessoas: as pessoas tendem a se comportamento conforme suas expectativas com relação a elas. Isso não significa que elas farão exatamente o que você deseja que elas façam, mas se você esperar algo positivo delas e demonstrar isso, a tendência é que elas terão comportamentos positivos, e vice-versa. Os autores 
dizem que "é fato que as pessoas melhoram ou pioram de acordo com suas expectativas e projeções".

Nem sempre é fácil lidar com comportamentos difíceis. Às vezes pode não ser tão complicado pelo fato de já termos passado por algo semelhante e, por isso, já temos uma abordagem para tal comportamento. Os dez comportamentos difíceis, listados pelos pesquisadores, são: "tanque de guerra", "atirador de elite", "granada", "sabe-tudo", "ele-pensa-que-sabe-tudo", "sim", "talvez", "nada", "não" e "reclamador".

- Tanque de Guerra: manter sempre a posição é uma das maneiras de lidar com esse comportamento, mas o objetivo é interromper o comportamento fazendo com o cliente volte sua atenção ao que realmente importa e comece a se acalmar. No lugar de contra-atacar, a defesa nesse caso é a explicação e a justificativa da venda do produto ou serviço. $\mathrm{O}$ importante é não ficar paralisado e ir contornando a situação até que o comportamento vai desaparecendo dando espaço para um novo diálogo, ressaltando que ele só respeita quem se impõe a ele.

- Atirador de Elite: mantenha sempre sua posição, mas nesse caso, utilize perguntas estratégicas para que o cliente responda e perceba que seu comportamento não está sendo adequado. Perguntas como "quando você disse isso, o que realmente queria dizer?" ou "o que isso teria a acrescentar na nossa negociação?" são perguntas que podem ajudar a "desarmar" o atirador de elite. Lembrando sempre que o profissionalismo, a cordialidade e a compreensão devem sempre estar em destaque em todos os momentos. Caso esse comportamento comece a tomar a forma de um "tanque de guerra", pode-se utilizar a estratégia do mesmo para melhorar a comunicação. Vale ressaltar que uma vez descoberto e visto não faz mai sentido para o "atirador" continuar atirando.

- Sabe-tudo: é necessário que o vendedor entenda muito bem do assunto, pois o "sabe-tudo" pode ser muito questionador. Perceba o que realmente é importante para esse cliente e foque nesse ponto para que ele crie uma harmonia com o vendedor. Colocar o "sabe-tudo" em posição de mentor, apresentando os pontos importantes indiretamente e não ficando ressentido com suas atitudes, pode ajudar no sucesso da comunicação. Não se deve transformar em um "sabe-tudo" para lidar com um, pois isso pode causar ainda mais conflito e estresse. Usando-o a fa- 
vor das vendas, ele pode ser muito positivo, pois de fato ele sabe muito mesmo.

- Ele-pensa-que-sabe-tudo: dar-lhes um pouco de atenção pode ser a chave do sucesso, lembrando sempre que é necessário esclarecer pontos específicos e falar a realidade como de fato ela é. Já que esse comportamento necessita de atenção, ao finalizar a negociação, fazê-la de forma honrosa pode trazer todos os benefícios possíveis para não causar algum tipo de má impressão. A ideia não é humilhá-lo, mas sempre entender sua necessidade de participar.

- Granada: o segredo para lidar com esse tipo de comportamento é prender sua atenção e focar naquilo que realmente o fez "explodir". Assim, a intensidade pode ser reduzida e o "granada" pode evitar ser "detonado" e causar maiores problemas. Escutar com atenção e enxergar esse comportamento de outra forma podem ajudar a fazer um caminho onde a comunicação possa ser mais eficaz. Criar empatia para perceber sua comunicação não verbal e quando o comportamento começa a aparecer dá tempo da pessoa represar seus sentimentos para explodir depois. Isso o faz sentir pior depois, visto ter orientação para pessoas.

- Sim: ter paciência para ser honesto e ajudar esse cliente a fazer um planejamento para finalizar a compra ajuda na comunicação. Além disso, fortalecer o relacionamento para que o cliente tenha confiança no vendedor pode fazer com que esse tenha mais comprometimento com relação à compra. Ele fará a compra se entender que esse é o melhor jeito de agradar o vendedor.

- Talvez: pressionar a pessoa "talvez" não é a melhor solução para que a comunicação seja mais eficaz. Para isso, é necessário estabelecer uma zona de conforto integrando o cliente ao universo da compra, revelar os conflitos e esclarecer todas as opções e criar a possibilidade de manter o contato do cliente, utilizando algum programa de fidelidade do estabelecimento. É importante estabelecer um processo de tomada de decisão, pois a pessoa "talvez" demora um pouco para se decidir com relação à compra. Tudo porque não quer ser desaprovado. Como os anteriores, ela precisa se sentir pertencente, participante do processo todo, pois quer se sentir importante. Entrar no jogo do "não" pode reforçar seu comportamento. O ideal é valorizá-la e depois contestá-la de modo inteligente e não arrogante. 
- Nada: é importante reservar tempo para esse tipo de comportamento. Coloque-se no lugar dela e crie uma conversa para chamá-la a ação da compra. Além disso, faça perguntas abertas mostre satisfação em atendê-la e mostre o futuro como algo promissor, que pode dar certo. $\mathrm{O}$ segredo é andar devagar com esse tipo de comportamento para que ele entre no ritmo da venda e feche o negócio.

- Não: o comportamento da pessoa "não" se reflete na sua resposta negativa antes mesmo de saber como funciona o produto e/ou serviço. Deixe-a livre para ser tão negativa quanto quiser, até que seu negativismo se esgote e os argumentos possam ser discutidos. Não se deve ficar na defensiva, mas apenas ser direto nas respostas e objeções, sempre com muita cautela e cordialidade que também poderá ser percebida pelo fato de deixar a venda em aberta e agradecer a boa intenção do cliente. Outra técnica que pode ser utilizada é fazer observações negativas antes mesmo de o cliente pensar nessa possibilidade, o que podemos considerar um efeito espelho. "Se você não comprar o produto, pode ser que amanhã esteja mais caro" é um exemplo. Ser cauteloso e verdadeiro também são ferramentas fundamentais nesse caso.

- Reclamador: escutar detalhadamente e selecionar os pontos principais são a chave para estabelecer um vínculo com esse cliente. Assim, será mais fácil ser mais específico na hora de uma interrupção e direcionar o foco para soluções. Estabelecer limites com cautela e mostrar os benefícios futuros podem fazer parte das técnicas abordadas para esse tipo de comportamento. Como esse cliente se sente desamparado por um mundo injusto, a tendência das reclamações é um fato natural em sua vida. Por isso, ao lidar com esse tipo de comportamento, seja compreensível ao ponto de levá-lo a reflexão de que, mesmo tudo sem negativo, a compra pode ser algo positivo por diversos aspectos.

Outro aspecto importante ressaltado na pesquisa é o "Efeito Pigmaleão". É o fenômeno que diz que quanto maior as expectativas que se tem com relação a uma pessoa, melhor será seu desempenho. Isso reforça a necessidade de se ter expectativas positivas com relação ao cliente, para que esse possa ter um comportamento mais agradável e menos difícil de lidar. Douglas McGregor 17, doutor em Harvard onde lecionou Psicologia Social, introduziu um estudo na década de 60 com gerentes e colaboradores, onde comprovou que as expectativas positivas da gerência geravam ações positivas dos colaboradores, 
assim também no caso das expectativas negativas. Portanto, se pode aplicar a teoria em organizações, na vida pessoal e, principalmente, no comportamento de consumo.

Para os autores, três dicas são importantes para o sucesso na comunicação:

- Ser um comunicador eficaz: buscar aprendizado e atualização constante faz com que o vendedor se torne cada vez melhor na arte da comunicação;

- Encontrar parceiros de comunicação: envolver-se com pessoas que já tenham essa habilidade bem desenvolvida ajuda a entender melhor as técnicas e a aplicá-las no dia-a-dia;

- Valorizar o que se tem de melhor: isso significa trabalhar as dificuldades e utilizar o potencial ao seu máximo para que se possa, além de ser um bom comunicador, alcançar satisfação pessoal e profissional.

\section{Possíveis Conflitos no Atendimento}

Todo atendimento é cheio de detalhes e pode ser um sucesso ou não, dependendo da maneira como é encarado. Os conflitos são naturais, pois fazem parte de um mundo onde as pessoas são diferentes. Um bom atendimento pode ser resumido em diálogos onde todas as partes saem satisfeitas, satisfazendo suas necessidades e desejos, seja de vender ou comprar um produto e/ou negócio. A negociação é uma técnica que deve ser estudada para ser mais bem aplicada.

Os conflitos então são consequência de ações e comportamentos que não visam a compreensão do cliente de um modo geral. Como os exemplos do PROCON e do SEBRAE, o maior problema está na falta de comunicação entre o cliente e o vendedor, onde todos querem falar e não conseguem ser compreendidos. Os conflitos devem sempre ser administrados com cautela para que possam ser resolvidos da melhor maneira possível. Afinal ambas as partes tem o mesmo propósito: fazer um bom negócio.

\section{Considerações Finais}

Conclui-se que a pesquisa feita pelos Drs. Rick Brinkman e Rick Kirschnerr nos mostra alguns comportamentos indesejáveis que podem ser trabalhados. Conquistar o consumidor tem sido uma tarefa cada vez mais difícil 
nos dias de hoje, mas não tem sido algo impossível. Os comportamentos podem ser trabalhados para que todas as partes envolvidas no processo de venda/compra possam sair satisfeitas da negociação.

Não basta apenas aprender os comportamentos, é necessário ser cordial, saber ouvir e praticar a paciência para que o vendedor possa alcançar uma compreensão cada vez maior do que realmente é importante para o cliente. $\mathrm{O}$ atendimento não depende somente do fato de existir um vendedor, mas da compreensão que ele tem dos comportamentos de seus clientes.

Não existe uma fórmula mágica para lidar com essas situações, o vendedor deve apenas ter disposição para aprender e praticar cada técnica que o levará a ser um melhor comunicador e negociador de um modo geral. Saber se comunicar é uma habilidade que serve para a vida toda.

\section{Referências Bibliográficas}

Atkinson, R.L. (2002). Introdução a psicologia de Hilgard/ Rita L. Atkinson, Edward E. Smith, Daryl J. Bem, Susan Nolen-Hoeksemae Carolyn D. Smith; trad. Daniel Bueno, 13. ed.. Porto Alegre: Artmed.

Bartels, R. (1998). The history of marketing thought. Columbus: Publihing Horizons, 1998.

Bolen, A. (2015). Business Analytics. Sete características do consumidor moderno. Disponível em: http://businessanalytics.pt. Acesso em: $20 \mathrm{de}$ ago. 2015.

Brikman, R. \& Kirschner, R. (2006). Aprendendo a Lidar com Pessoas Difíceis. Primeira Edição. Rio de Janeiro: Sextante. (Série Você S/A, Coleção Desenvolvimento Profissional, Volume 1).

Consumidor Moderno. (s.d.). Como é a experiência do cliente no e-commerce brasileiro?. www.consumidormoderno.com.br. Acesso em: 17 de ago. 2015.

Dica de Escrita (s.d.). Criação de Personagem - Pirâmide de Maslow. Disponível em: www.dicasdeescrita.com.br. Acesso em: 17 de ago. 2015.

Giglio, E. (1996). O comportamento do consumidor e a gerencia de marketing. São Paulo: Pioneira.

Goodman, G.F. (2012). Engagement Marketing: How Small Business Wins in a Socially Connected World. Primeira Edição. EUA: Constant Contact. 
Como lidar com clientes difíceis. Uma releitura do trabalho do Dr. Rick

Kotler, P. (1998). Administração de marketing: analise, planejamento, implementação e controle. São Paulo: Atlas, 5.ed.

Kotler, P. \& Armstrong, G. (1998). Princípios de marketing. Rio de Janeiro: Phb, 7. Ed.

Lucena, F. (2015). Consumidor moderno: faça a conta. Disponível em: www.varejista.com.br. Acesso em: 20 de ago. 2015.

Mata, V. (2015). Como deve ser um bom atendimento ao cliente em sua empresa?. Sociedade Brasileira de Coaching. Disponível em: www.sbcoaching.com.br. Acesso em: 18 de ago. 2015.

Melo, L. (s.d.). Rato na Coca-Cola nunca existiu, conclui TJ-SP. http://exame.abril.com.br. Acesso em: 17 de ago. 2015.

Pequenas Empresas Grandes Negócios. (s.d.). Como satisfazer um cliente chato e aprender com as críticas dele. Disponível em:

http://revistapegn.globo.com. Acesso em: 18 de ago. 2015.

Procon. (s.d.). Reclamações Fundamentadas 2014. Disponível em: http://sistemas.procon.sp.gov.br. Acesso em: 17 de ago. 2015.

Sebrae.(s.d.). O sucesso nas vendas depende de bom atendimento. Disponível em: www.sebrae.com.br. Acesso em: 20 de ago. 2015.

Silva, L.J.O.L. (2002). Implicações cognitivas e sociais da globalização das redes e serviços telemáticos. Tese de doutoramento. 458p. Departamento de Comunicação e Arte. Universidade de Aveiro- Portugal.

Souza, F. (s.d.). Você Vencedor. A Profecia Auto-realizável. www.vocevencedor.com.br. Acesso em: 17 de ago. 2015.

Vaz, C.A. (2011). Os 8 Ps do marketing digital: o seu guia estratégico de marketing digital. Primeira Edição. São Paulo: Novatec Editora. 
$\bigoplus$

$\bigoplus$

$\oplus$ 


\title{
On the implications of non-translation in Portuguese advertising: names in cosmetic products as a case in point
}

\author{
Sandra Gonçalves Tuna \& Elsa Simões Lucas Freitas \\ Universidade Fernando Pessoa \\ E-mail: stuna@ufp.edu.pt / esimoes@ufp.edu.pt
}

\begin{abstract}
The issue of advertising translation inevitably raises that of international marketing. One of the preliminary assumptions underlying product internationalization seems to be the widespread belief in significant similarities between people from different world regions and cultures, which has led to a fairly high degree of standardization in many product features. This is the case of many cosmetic products, sold worldwide with identical advertising strategies. Despite divergent approaches to international campaigns adopted by different cultures/countries,

translation. Whether translation includes pictorial or textual elements, or both, it also seems to depend on cultural issues. In Portugal, international campaigns of cosmetic products seldom involve profound incursions into the advertisement layout. Except for the copy text, there are several elements that remain unscathed in Portuguese adverts: overall structure, pictures and names. The present paper will address these issues, trying to infer some of the implications that this translational option might bring to cosmetic advertising.
\end{abstract}

Keywords: Translation; international advertising; names; cosmetics.

\section{Introduction}

$\mathrm{T}^{\mathrm{T}}$ is barely surprising that product names should play a significant role in marketing strategies and that they are therefore object of careful consideration by marketers, sellers and manufacturers. Regardless of names' semantic properties, and their relationship with the nature or purpose of a given product, names on the label will identify a given good, the brand, and will constitute a distinctive feature relative to analogous products or brands. This partly explains why companies often dedicate a significant amount of their time, effort 
and budget to finding the right name for a brand or a product, eventually resorting to naming specialist firms (Hammel, 1997, pp. 1-2). Naming and branding specialists regard this stage as a crucial one and claim that there are several factors underlying the assessment of a good name: 'difference, meaning the name must differentiate the product, relevance and customer engagement' (Birkner, 2001, p.6).

Today, in an internationally-oriented market, products frequently cross borders and all the factors and implications involved in the choice of a product/brand name become more complex, and one of the stages of the marketing process will definitely have to consider whether the product/brand name will be maintained, changed, translated or adapted in some way. This decision will have consequences for brands, from aspects related to brand image and coherence to budgetary conditions, and will also be influenced by the target culture(s) system(s), as it is ultimately the host culture that will determine the success of any marketing decision.

The present study will focus on the strategy adopted by cosmetics brands regarding product names, as these are products especially amenable to internationalization, and have long been exporting products. While it will consider the translational options used for the Portuguese market, examples from other cultures will be taken into account for comparative purposes.

\section{On the nature of advertising names}

Louis Goossens (1985) analyses advertising names by looking at different dimensions of meaning, namely 'reference' - the reality to which the name refers - and 'sense' - the semantic meaning. He also considers the 'extension' of names, the class of things to which the name applies, as well as its 'intension', which refers to the essential properties related to the term. He further argues that product names, like other proper names, are primarily referential, but, unlike other proper names, they are associated with a series of products belonging to a given product type. Therefore, in terms of extension, a product name may refer to a series of entities, and, as far as intension is concerned, the product name 'is the sum of properties shared by all instantiations of $\mathrm{P}$ [product name] that is to be taken as its intension' (1985, p.99). Within this framework, Clarins Bright Plus, for example, refers to all creams advertised (and sold) under that name, which means that its extension comprehends the 
On the implications of non-translation in Portuguese advertising: names in cosmetic products as a case in point

product range bearing that name, namely exfoliators, day/ night creams and masks, and its intension concerns the properties associated with this range of products.

As far as the 'sense' of the product name is concerned, which is the dimension of meaning that can be particularly problematic when advertisements cross linguistic boundaries, Goossens considers two possibilities: descriptive names, which directly point to the product type, and names which, despite using ordinary words, do not rely on their descriptive character, but on the associative meaning, which is expected to invest the product with a positive image. Cosmetic names, though often descriptive, also seem to benefit from associative meaning as, besides the meaning implied by the carefully chosen words that compose the name, they draw significantly on the meanings generated by the terms used. And, in addition to the dimensions suggested by Goossens, the connotations and associations of cosmetic names are largely dependent on the image that a particular brand already has and on the image conveyed by the specific advertising of the product:

Meaning of this associative type is often exploited to the full by advertisers. Much of the suggestive (and manipulative) power of advertisements may reside in the fact that the boundary line between sense and non-constitutive associative meaning is not always easy to draw. (p.102)

Dyer also emphasises the associative and connotational dimensions of product names, explaining that, when naming a product, advertisers try to 'invest it with particular meanings and associations. The name should do more than just label or identify the product; it should bring flattering associations to mind, associations which help to sell it' (1982, p.141). While analysing the functioning of name attribution to luxury products such as perfumes (and, by extension, to high-priced cosmetic products), Cook also points out the advantages of ambiguity in such naming: 'Perhaps the most effective names are those which arouse many different connotations, allowing the product to appeal to incompatible desires within one person, or to different types of people.' (1992, p. 106) 


\section{On the nature of names in cosmetic products}

Cosmetic names often consist of a tripartite structure: the brand name, the product line, and the product name or function: Shiseido - Vital Perfection Balancing Softener. A bipartite structure, consisting of the brand name and the product name, is also common: Dior - Capture Essentiel. In such cases, the function or purpose of the product is sometimes provided in smaller print, as well, which means that, in the end, the structure is essentially tripartite in terms of information. There is an obvious descriptive tone, as at least one part of the name indicates the very nature and/or function of the product they denominate. According to Goossens's model (1985), described above, the descriptive dimension of cosmetic products' names is fundamental, for they normally consist of common nouns, whose ordinary meaning (or denotational meaning) is expected to be taken into account, with no detriment to the connotations they may benefit from. On the contrary, the non-constitutive associative meaning plays a part in names that have a clear advertising function:

$$
\begin{aligned}
& \text { Clinique - Anti-Blemish Solutions - Clarifying Lotion } \\
& \text { Clinique - Anti-Blemish Solutions - Clearing Moisturiser } \\
& \text { Clinique - Redness Solutions - Daily Relief Cream } \\
& \text { Clinique - Redness Solutions - Soothing Cleanser } \\
& \text { Clinique - Redness Solutions - Daily Protective Base } \\
& \text { Shiseido - Benefiance WrinkleResist - Extra Creamy Cleansing Foam } \\
& \text { Shiseido - Benefiance WrinkleResist - Balancing Softener } \\
& \text { Yes to Tomatoes - Truly Terrific - Body Butter } \\
& \text { Christian Dior - Deep Radiance - Exfoliating Cream } \\
& \text { Clarins - Youthful Vitality - Multi-Active Night Lotion }
\end{aligned}
$$

We could be led to believe that such descriptive names would occur more often in skincare products, as they clearly need to indicate the specific function(s) and target group or skin/hair types they are aimed at, but there are plenty of examples from makeup products as well:

Shiseido - Translucent Loose Powder

Shiseido Luminizing Lip Gloss 
On the implications of non-translation in Portuguese advertising: names in cosmetic products as a case in point

\section{Shiseido Pore Smoothing Corrector}

Helena Rubinstein - Wanted Eyes - Perfect Color Blend Eyeshadow

Helena Rubinstein - Illumination - Natural Radiance Reviving Loose Powder

Indeed, even acknowledging the substantial meaning potential of cosmetics names, as defended by Merskin in a thorough analysis of lipstick names 'By using specific linguistic signs and symbols, lipstick names confer attitude, behavior, and/or access to a less fattening indulgence' (2007, p. 598), - It is still clear, in the results this author provides (597) that a considerable part of names $(20 \%)$ relate to product colour, thus providing a descriptive feature.

More than just trying to create a mood or image, the names provided are closely connected with the products' properties and functions. Names carry a characteristic of the product and the advertising promise. This means that the information provided by the product name displayed in advertisements may actually bring about changes in the audience's perception of the product, resulting in either a favourable attitude - grabbing their attention - or, a negative one, causing them to regard the product as unsuitable for their specific needs. In either case, this kind of information seems to be significant in terms of audience response, as it provides criteria for the selection of the product involved.

\section{On the translation of product names}

It seems rather evident that names play an important role in the advertising strategy, since the latter frequently evolves around the motto provided by the product name. Often, visuals, including typographical features, headlines and copy are built around the meanings - allusions, associations and connotations - suggested by cosmetic names, which may also inspire other marketing elements, including the packaging. The name works as a kind of overall theme, from which the advertising concept and message develop: $n$ Biotherm Aquasource advertisement, for example, as the name suggests, the main advertising promise is deep hydration. The light green skin cream jar is thus depicted in deep water, releasing air bubbles, with a bluish background. The text reinforces this watery scenario: 
Now Hydration goes deep. New Formula Aquasource. With thermal plankton cellular water. Paraben Free. Get fresh radiant skin all day long. The same detectable texture and scent now hydrates deeper than ever before!

Likewise, an advert for a Clinique foundation - Dewy Smooth, which promises an 'All day dew' (title), uses a picture of the product jar leaning against dewy deep green grass, where dew drops are foregrounded.

The prodigal semiotic potential of names becomes ever more visible when these cosmetics are exported to different cultures and languages, as translation, adaptation or alteration will directly impend on the desired meanings and associations for a given name. Both marketers and translators recognize the challenge and struggle with such challenge. International brands present different approaches: some provide translations, an option that is not so common in cosmetic products, others provide parallel translations and others use a standardized strategy.

Guidère (2000, p. 93) questions the translatability of advertising names, given their strong connotative value and culture-bound nature, since their effectiveness depends on the audience's shared knowledge to establish the desired associations. He discusses three translation strategies adopted to deal with product names in international marketing: transplantation, transliteration and transmutation. Of the three procedures suggested, the one that is used in Portuguese cosmetic marketing is 'transplantation', which implies the transfer of the product name without any change, in the original language. According to this author, the latter strategy is used by leading brands, which have reached a world-wide status that grants them recognition. This may be partly the case in Portugal if we consider brand names alone. Product names, however, need to be handled differently since they commonly derive from common names which would be translatable most of the times. Guidère claims that even in this case it would not be easy to find equivalents that would preserve a comparable connotative value in the target language, and that the naming systems are inescapably different from language to language (2000, p. 94-95). His view seems to suggest that there would probably be a loss of illocutionary force if names were translated. While these factors may eventually influence the strategy of non-translation, it seems that advertisers are more likely to be moved by marketing reasons, since, in addition to economic advantages asso- 
On the implications of non-translation in Portuguese advertising: names in cosmetic products as a case in point

ciated with standardization of names, their preservation also increases brand consistency (Yeshin, 2006, pp. 421-422).

Identical strategies used in overseas countries, namely in East Asian countries, such as China, seem to corroborate Yeshin's point of view, as a study conducted by Chang (2008) illustrates by examining the effectiveness of adopting a global look in the Asian market. In this study, in addition to displaying Western models in advertisements aimed at East-Asian audiences, marketers employ foreign, namely, English brand names to emphasise the product's or brand's global character. This is a strategy used both by multinationals, with standardization purposes, and by local marketers who wish to endow their brands/products with global properties and style (2008, pp. 200-202).

\section{Cosmetic names in translation}

The names of cosmetic products, like many other products which are marketed at an international level, usually remain untranslated in Portuguese. As mentioned above, 'transplantation' is the most frequent translational approach. This option seems to be motivated by the reasons discussed for other international products: in addition to the fact that most cosmetic adverts belong to long-established hegemonic brands, as well as the economic advantages of standardization, cosmetic names in other languages may also gain from the association with their country of origin or the language used. Also, some names may be easily understood by the Portuguese audience due to phonetic or spelling similarities:

\begin{tabular}{|l|l|}
\hline Estée Lauder Revelation & Revelacão \\
\hline Estée Lauder Perfectionist & Perfeccionista \\
\hline Estée Lauder Idealist & Idealista \\
\hline Estée Lauder Verité & Verdade \\
\hline Helena Rubinstein Illumination & Iluminacão \\
\hline Lancôme Adaptîve & Adaptável \\
\hline
\end{tabular}

On the other hand, the frequently functional and descriptive nature of cosmetics names, in addition to their prominent position in advertising pictures, may raise relevant translational and language issues. 
Cosmetics advertising relies increasingly more on pictures, which often depict the packaging in close-up, making names stand out significantly. Thus, it appears that by leaving these elements untranslated, Portuguese versions may become less accessible to the readers, who may fail to fully understand the properties or the specific type of product advertised. Once again, it seems important to consider the non-arbitrary nature of cosmetics names, which, as expected, are carefully chosen so as to bring positive associations to mind in addition to being normally meaningful and descriptive. As claimed by Dyer (1982, p.141), 'names given to cosmetics and other beauty products frequently recall images of beauty, cleanliness, sophistication and naturalness'. Besides, the pseudo-scientific discourse, so commonly employed in cosmetics advertising, often begins with the very name of the product:

Biotherm Skin Energetic Serum

Biotherm Biosource

Chanel Ultra Correction Line Repair

Clinique 3 steps

Elizabeth Arden Ceramide Gold Ultra Restorative

Estée Lauder Resilience Lift Extreme

Lancaster Differently Nutri-Dermo Skin

Lancôme Rénergie Morpholift R.A.R.E. ${ }^{\text {TM }}$

Lierac Phytolastil

L'Oreal Derma Genèse

Vichy Aqualia Thermal

Vichy Normaderm

A closer examination of two versions - English and Portuguese - of an advert for a Lancôme mascara may help clarify this point and offer further issues for analysis. The product is called Hypnose Doll Eyes, a name that is both very descriptive and associative, and that may pose some language obstacles. Though the expression might be recognised by a significant number of potential consumers, especially if aided by the visuals, which are rather self-evident, the Portuguese advertisement includes an additional explanatory 
On the implications of non-translation in Portuguese advertising: names in cosmetic products as a case in point

sentence, so as to make sure the product function or objective is well understood, especially if we take into account that this expression is not part of the habitual jargon of cosmetic names: "A $1^{\mathrm{a}}$ mascara efeito "pestanas de boneca" ('The $1^{\text {st }}$ mascara to give a doll lash effect').

The marketing approach used in Portuguese advertising is not adopted in all countries and is definitely different from that encountered in English advertising. Commonly, product names, including brands other than those belonging to English-speaking countries, are provided in English. It is not at all unusual to find French products that display both French and English names on the packaging. Though there are some brands that use English alone (such as MaxFactor), the most common strategy is to use both English and French, at least in the translation of the third part of the threefold name structure of cosmetics, as it is the one containing the descriptive element:

Clarins - Baume Couleur Lèvres / Colour Quench Lip Balm

Clarins - Doux Exfoliant / Gentle Exfoliator - Lotion de Clarté / Brightening Toner

Bobbi Brown - SPF Tinted Moisturizer 15 / Hydratant Teinté SPF 15

Lancôme - Adaptîve - Fond de Teint Re-Equilibrant en Continu /Continuous Skin-Balancing Makeup

Lancôme - Effacernes Longue Tenue - Soin Teinté Unifiant Anticernes / Long-Lasting Softening Concealer

Lancôme Primordiale Skin Recharge - Soin Renovateur Lissant Visible IP 15 / Visible Smoothing Renewing Moisturiser SPF 15

International brands (from various origins) tend to name their products in English, which seems to confirm that English is used as a tool by internationally-oriented brands, and that though French is traditionally associated with cosmetology, it has lost its dominance over English, which has invaded a previously unchallenged domain. Notwithstanding, the prestige of French language is still patent in French (sounding) names, and in the use of 'Paris' below the brand name, even in the case of brands that have been taken over by big international groups from other countries, as in CLARINS Paris, L'OREAL Paris or LANCÔME Paris:

One might imagine that the popularity of the French language in perfume [and cosmetics] advertising is partly because the French have his- 
torically dominated perfume [and cosmetics] production, but it seems to relate more to a facet of snobbery. France is universally regarded as superior in matters related to fashion, so that an understanding of things French in this domain is a sign of one's social standing. The advertiser flatters the addressee, a strategy which is alleged to be successful in advertising [...]. (Tanaka, 1994, p. 56)

Whichever strategy is used, what seems to be more relevant for the present analysis is that language may become an issue in Portuguese advertising, as often the Portuguese audience will have to look at the copy to fully understand the properties and/or functions of the advertised products. This may have consequences in terms of advertising impact, especially if we consider the very poor attention the copy normally gets from readers, and that pictures, including the depicted packaging, are more instantly grasped by the potential consumer, even though the interpretation of visual material is culture-bound up to a point (Messaris, 1997, pp. 90-93).

\section{Factors and implications of non-translation in cosmetic products' names}

Previously, we have anticipated a number of factors and effects associated to the use of names of cosmetics in other languages than Portuguese, namely English and French, especially in the context of advertising. This section will attempt to provide a more comprehensive analysis, as, like with most marketing options, the factors contributing to certain strategies are often complex and manifold.

As far as motivating reasons are concerned, it is possible to single out the most pervasive:

a) Economic reasons: standardization implies lower marketing and advertising costs;

b) Brand consistency: maintaining the same name means that the band and product become widely recognised with more or less consensual connotations (see, for example, Belch \& Belch, 2004, p. 669, Yeshin, 2006, p. 422, Wells et al, 1998, p. 682);

c) Country-of-origin effect (see Mueller, 1996, p.31): associations between languages and countries benefit from maintaining names untranslated; in this case, language becomes a key strategic marketing element. 
Therefore, we may expect such names to allude to trendiness, chic, expertise, among other values associated with the cultures at stake. In the case of names in English, however, this is not always the case, as many brands from non-English-speaking countries adopt English names. Cosmetics products and adverts, as the above examples show, repeatedly include product names in English (even in parallel with other names), which is seems to stress the international charisma of the product rather than 'made in' effect, has Piller has demonstrated in various studies dedicated to language contact and multilingualism in advertising (2003, p.175): 'Internationally, English has become a general symbol of modernity, progress, and globalization'.

d) Imported product effect: closely associated with the 'international' product effect, it seems clear that international brands enjoy prestige in the target country. This seems to be a commonly acknowledged factor in the use of English in advertising. The study of the Asian market mentioned above regards this as an overriding factor, and it has also been pinpointed in studies of multilingual advertising in different countries. An example of this is Piller's analysis of multilingual adverts in Germany, where the author states that 'In the vast majority of advertisements that use English, it is the language of international communication and not the language of a particular national community (2003, p.164).

e) Favourable cultural environment: names and other cases of more blatant foreignness in advertising seem to indicate a cultural environment that welcomes interference from other languages in advertising. It is also implied by this vector the fact the audience is expected to understand the terms used. In the case of cosmetology, in the scarcity of Portuguese products of the type, the audience is likely to be even more used to the jargon (both in French and in English), as most advertisements (and products) come from international foreign) brands.

Piller adds another relevant effect to the use of foreign languages that could easily be of paramount importance in the case of cosmetics product names: prolonged attention: 'A general advantage of the use of a foreign language is that it impedes automatic processing and thereby arrests the attention of recipients for a longer timespan than monolingual native-language adverti- 
sements would' (2003, p.163). While it is not certain that this is a deliberate goal of advertisers' strategy, it is, at least, a favourable outcome.

The possible effects that may be elicited from the use of these strategies could be, however, more complex and multidimensional. Authors such as Yeshin point out a number of factors that can affect international advertising, and which can, therefore, make a difference to the outcome of the campaign: after language (the paramount vector in this process), others can be put forward, such as differences in culture and tradition, which include the audiences' perception, motivation, learning and memory, meaning, age, self-concept, group influence, social class, sex roles, decision making models, purchase patterns, motivational factors and aspirations, loyalty and purchasing environment, post-purchase expectations and standards of living (2006, p.423).

Other authors, such as Wells et al dwell on the specific difficulties concerning international advertising, referring to, in the first place - as would be expected - to considerations relating to customs and culture, closely followed by a mention of marketing imperialism, which is intimately associated with the issue of global brands. Even more importantly within the scope of the present work, they also foreground the importance of emotions felt by the receiving end of this process towards the 'foreign' goods that are being advertised, such as inertia, resistance, rejection and politics in general (1998, pp. 689-692). For the specific purposes of this article, the following effects can be singled out:

a) Intelligibility: this seems to be one of the most relevant points to be considered. It is indisputable that advertisers count on the fact that many of the terms used in names are understood by the audience, and that the use of such words in other languages may even raise new connotations, thus enriching the advertising message, as Cook explains, 'simply by attracting the extra connotations of the culture of which they are an index' (1992, p. 107). Furthermore, the hegemonic spread of Englishspeaking cultures and the fact that French originates from Latin, thus presenting many similarities with the Portuguese language, ensures a desirable degree of intelligibility. Besides, these products are normally created to be marketed internationally, which means that names are taken into careful consideration so as to evoke positive associations in 
On the implications of non-translation in Portuguese advertising: names in cosmetic products as a case in point

as many cultures as possible. Nonetheless, advertisers should count on some meaning loss, as well. It is hardly surprising that a lot of relevant information contained in product names will be overlooked, or lost 'in non-translation', and only compensated if readers take the trouble to read the advertising copy, which is rather unlikely.

b) Impact: as far as the advertising effects are concerned, the above paragraph points to some relevant aspects. If, on the one hand, advertisers can count on a collateral encouraging effect, such as 'country-of-origin' associations, among others, they should also take into account the loss of impact of certain advertisements that rely mostly on packaging information and pictures, as well the eventual need for completing the visual cues provided.

c) Cultural implications: the implications of such strategies may go well beyond the factors just discussed. On the one hand, they pose translation issues, namely those concerning the norms that prevail in the target culture and which govern translation procedures. On the other hand, foreignness leads to a re-evaluation of power relations in international advertising, namely the spread of influence of dominant cultures over less powerful ones, as well as to the way we perceive ourselves and the Other. Names seem to be only the tip of the iceberg, as, if we look more deeply into it, Portuguese advertising discourse is colonised by foreign terminology.

As we may see, these factors and implications raise several issues, not only those directly connected with marketing and business considerations, but also those concerned with cultural dimensions. Indeed, what seems to favour the adoption of standardized global approaches is the cultural environment: the audience's receptivity to interference. In the Portuguese case, as foreignness often extends to other parts of the advertisement, we may regard nontranslation as part of the translational norms concerning advertising texts. Indeed multilingual adverts are common, not only but also in cosmetics adverts. This trend does not seem peculiar of the Portuguese advertising landscape, as some of the studies mentioned in this article reveal (Piller, 2003 and 2006; Yeshin, 2006; Chang, 2008), as they point to identical circumstances in different countries, but it does play a significant role in Portuguese advertising, which displays different forms of presenting hybridity: through product name, 
through copy in other languages (namely English), through mixed-language adverts, and through parallel translation.

\section{Final remarks}

This short incursion into cosmetics names in advertising has just only unveiled a much wider issue concerning translation of international advertising, but it has nonetheless approached relevant issues within this area. It has looked into the complexity involving product naming, concentrating on the specificity of cosmetic names, which pose peculiar questions due to their tripartite structure and character of names. The latter analysis served mostly to demonstrate the implications that leaving names - and cosmetics' names, in particular - untranslated may originate and that such marketing option, despite being motivated by rational factors, could have multifarious effects in audience reception, and hence response.

This discussion can be taken even further, as we have seen, to issues related to the cultural international and national environment, and thus to norms governing translational practices and to the circumstances that underlie such practices. It seems that the translation strategies adopted by marketers do reflect conformity with the source culture, in addition to the commercial/economic motives, based on advertisers' belief in the potential benefits they may draw from the prestige and influence of a powerful culture in the receiving system. This argument can point to a series of even more complex reflections, including power relations between languages and cultures and their perpetuation and/or mirroring by advertising discourse.

\section{Bibliography}

Belch, G. \& Belch, M. (2004). Advertising and Promotion: An integrated marketing communication perspective. New York: McGraw-Hill.

Birkner, C. (2001). What's in a Name? Naming a new product is more than just a creative exercise. Marketing News, 45(4).

Chang, C. (2008). The Effectiveness of Using a Global Look in an Asian Market. Journal of Advertising Research. June: 199-214.

Cook, G. (1992). The Discourse of Advertising. London and New York: Routledge. 
On the implications of non-translation in Portuguese advertising: names in cosmetic products as a case in point

Dyer, G. (1982). Advertising as Communication. London and New York: Routledge.

Goossens, L. (1985). What's in an Advertising name?. In G. Debusscher \& J.-P. Van Noppen (Ed.) Communiquer et Traduire: Hommages à Jean Dierickx (pp. 95-102). Bruxelles: Éditions de L’Université de Bruxelles.

Guidère, M. (2000). Publicité et Traduction. Paris: L'Harmattan.

Hammel, S. (1997). What's in a name? For the pros, big bucks. News and World Report, 123(14).

Merskin, D. (2007). Truly Toffee and Raisin Hell: A Textual Analysis of Lipstick Names. Sex Roles 56: 591-600.

Messaris, P. (1997). Visual Persuasion: The Role of Images in Advertising. Thousand Oaks: Sage.

Mueller, B. (1996). International Advertising: Communicating Across Cultures. Belmont CA: Wadsworth Publishing Company.

Piller, I. (2003). Advertising as a Site of Language Contact. Annual Review of Applied Linguistics, 23: 170-183.

Piller, I. (2006). Identity constructions in multilingual advertising. Language in Society, 30: 153-186.

Tanaka, K. (1994). Advertising Language: A pragmatic approach to advertisements in Britain and Japan. London: Routledge.

Wells, W.; Burnett, J. \& Moriarty, S. (1998). Advertising : Principles \& practice. London, Sidney, Toronto: Prentice-Hall International Editions.

Yeshin, T. (2006). Advertising. London: Thompson. 